http://kitaibelia.unideb.hu/

ISSN 2064-4507 (Online) • ISSN 1219-9672 (Print)

(C) Department of Botany, University of Debrecen, Hungary

24(2): 173-226.; 2019

DOI: $10.17542 /$ kit.24.173

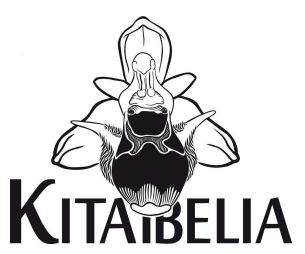

\title{
Adatok a Tarnavidék, az Upponyi-hegység és környéke flórájához
}

\author{
SULYOK József ${ }^{1}$ \& BERÁNEK Ábel ${ }^{2}$
}

(1) Bükki Nemzeti Park Igazgatóság, H-3300 Eger, Sánc utca 6.

(2) H-3600 Ózd, Bolyki fóút 107.; heureca@protonmail.com

\section{Contributions to the flora of the Heves-Borsod and Uppony Hills and adjacent territories}

Abstract - Results of nearly two decades of floristic research in the territory of Heves-Borsod Hills (Tarna-vidék) and the northern foreground of the Bükk Mts are presented in this paper (altogether 4421 records; BÁ: 1665, SJ: 2752). Several old literature records - partly supported by vouchers - are confirmed, e.g. Hypericum elegans and Lappula heteracantha from the Uppony Gorge, as well as Cephalaria transsylvanica, Cypripedium calceolus, Diplotaxis erucoides and Plantago indica from the Heves-Borsod Hills and the northern foreground of the Bükk Mts. Other former literature records (partly from the authors) are revised. These revisions are mainly due to changes in taxonomic concepts of some genera in new keys (Carex, Chamaecytisus, Epipactis, Molinia, Sorbus). Old literature and herbarium records of other significant taxa (Onosma visanii, Scutellaria columnae, Sorbus sp., Utricularia bremii/minor) are revised too. The new occurrence of Ferula sadleriana in the Uppony Gorge is probably the result of intentional seed dispersal. Of the many rare plants listed in our paper some are new for the flora of the region under study: Agrimonia procera, Alchemilla micans, Asplenium adiantum-nigrum, Astragalus austriacus, A. exscapus, Blysmus compressus, Carex appropinquata, C. cespitosa, Catabrosa aquatica, Centarea indurata, Dactylorhiza $\times$ aschersoniana, Epipactis voethii, Epipogium aphyllum, Equisetum hyemale, Festuca drymeja, Gagea bohemica, Glyceria nemoralis, Hesperis sylvestris, Myosotis caespitosa, Phegopteris connectilis, Platanthera chlorantha, P. $\times$ hybrida, Rosa gizellae, Scilla kladnii, Senecio doria, Solanum villosum, Taraxacum palustre, Triglochin palustre. Two phytocoenological relevés representing the habitats of Myosotis caespitosa and Spiraea media are presented. Currently known local distribution of some montane and forest-steppe elements are shown on maps.

Keywords: distribution, floristic record, Heves-Borsod Hills, rare species, Uppony Hills

Összefoglalás - Cikkünkben a Tarna-vidék és a Bükk északi előtere közel két évtizedes florisztikai kutatásának eredményeit foglaljuk össze, 4421 előfordulási adat közlésével (BÁ: 1665; SJ: 2752). Számos régi irodalmi, illetve herbáriumi adat megerősítést nyert: kiemelendő a Hypericum elegans és a Lappula heteracantha az Upponyi-szorosból, a Cephalaria transsylvanica, Cypripedium calceolus, Diplotaxis erucoides és a Plantago indica a Tarna-vidék és a Bükk-hát területéről. Néhány korábbi (részben saját) adatot revideáltunk, főleg az újabb határozókulcsok felfogásához igazodva (Carex, Chamaecytisus, Epipactis, Molinia, Sorbus sp.). További irodalmi és herbáriumi adatok is javításra kerültek (Onosma visanii, Scutellaria columnae, Sorbus sp., Utricularia bremii/minor). A szerzők megemlítik a Ferula sadleriana felfedezését az Upponyi-szorosban, ez az előfordulás valószínűleg magszórás eredménye. A szerzők cönológiai felvételeket közölnek a Myosotis caespitosa és a Spiraea media élőhelyeiről, továbbá néhány montán- és erdőssztyep faj jelenleg ismert lokális elterjedését is tárgyalják.

Kulcsszavak: elterjedés, florisztikai adatok, Heves-Borsodi-dsg., ritka fajok, Tarnavidék, Upponyi-hg. 


\section{Bevezetés}

Cikkünkben a 2000 és 2018 között gyüjtött adatainkat tesszük közzé. Most kerülnek publikálásra például azok az orchidea adatok, amelyek bekerültek Magyarország orchideáinak atlasza (MolnÁR 2011) elterjedési térképeire, majd az adatok átadását követően a „Flóraatlasz”ba (BARTHA et al. 2015), de részletes publikálásuk mindeddig elmaradt (pl. Epipactis albensis, E. neglecta, E. voethii).

Kutatási területünk, a Mátrától északra, a Medvestől keletre elhelyezkedő homokkővidék (más néven Heves-Borsodi-dombság, Kis-Bükk, Medves-Vajdavár-vidék, Ó-Bükk, Ózdidombvidék, Ózd-Pétervásárai-dombság, Pétervásárai-dombság, Vajdavár homokkővidék) és az attól keletre elhelyezkedő Upponyi-hegység - Bükk-hát vonulatának kistáji felosztásában mindmáig nincs teljes egyetértés (pl. HEVESI 1978, MAROSI \& SOMOGYI 1990, DöVÉNYI 2010, BARÁz 2014, CSORBA et al. 2018). Az egyes kistájak elhelyezkedését részben már mi is bemutattuk (SULYOK \& SCHMOTZER 1999, BERÁNEK 2007), azonban korábbi munkáinktól eltérően most célszerűnek láttuk a mind alapkőzet, mind növényzet szempontjából karakteresebb Pétervásárai- és Ózdi-medencét is elkülöníteni (1. ábra). A homokkővonulat nevének pedig a botanikai irodalom által talán leginkább használt Tarnavidék elnevezést választottuk (pl. SUBA 1969, BAKALÁRNÉ et al. 1975, BENEDEK \& ZAY 1987).

A Tarnavidék és az Upponyi-hegyhát botanikai kutatásának történetét többé-kevésbé részletesen taglaltuk korábbi munkáinkban (SULYOK \& SCHMOTZER 1999, BERÁNEK 2007), ezt most kiegészítjük az Upponyi-hegységre vonatkozóan is. Az alapkőzet szempontjából rendkívül változatos hegység két részre tagolódik, amelyből az Upponyi-rög az, amelyik a magját képezi, mészkőtömegével. Az Upponyi-szoros pedig ebből is kitűnik, melynek növényzete inkább már a Bükkhöz hasonlatos.

Az Upponyi-hegység botanikai kutatása az ezredfordulóig gyakorlatilag megegyezett az Upponyi-szoros flórájának és vegetációjának a feltárásával, esetleg néhány egyéb szórványadat közlésével. A hegységből Budai József tudósít elsőként néhány növényről (BuDAI 1914), amelyek közül kiemelendő a Cotoneaster integerrimus a Három-kőről, vagy a Sesleria hungarica (S. Heufleriana néven) és a Helianthemum canum felfedezése az Upponyi-szorosban. Őt követte Zólyomi Bálint (ZóLYOMI 1928, 1934), aki tovább bővítette a szurdok fajainak körét a Gymnocarpium robertianum, Aconithum anthora, Saxifraga paniculata és a Cotoneaster niger fajokkal. A Bodó-tóból kérdőjellel közli az Utricularia minort „Utricularia minor L.? (det. Soó)” (ZóLYOMI 1934), amely bizonytalan, némileg ellentmondásos határozáson alapult, hisz a Bodó-tó hidrológiai viszonyai, növényzete messze esnek az Utricularia minor életfeltételeitől. Az MTM Növénytárában az eredeti lapot megnézve az „Utricularia minor L. /U. Bremii Heer ?/ det. Soó” határozást 1967-ben revideálta Siegfried Jost Casper, aki az alábbi felirattal látta el a lapot „Utricularia vulgaris L. non minor, non bremii!!” (BP-225343).

1933-ban Hulják János az Onosma visianii előfordulásáról ad hírt Upponyból, közelebbi helymegjelölés nélkül (HULjÁK 1933). Az O. visianii előfordulása jelenleg nem bizonyított, a felméréseink során csak Onosma arenaria subsp. pseudoarenaria került elő a szurdokból. A MTM Növénytár gyűjteményét átnézve a keresett lapot nem találtuk meg, így ez a kérdés nyitva maradt, viszont érdekes és elgondolkodtató adalék, hogy az Onosma anyagot 2006ban revideálta Vladislav Kolarčik, aki a Hulják János által a Nagy-Galyán (Ásottfa-tető) és a Ruda-galyán gyűjtött Onosma visianii lapokat Onosma arenaria-ra javította. Így jelenleg a Bükkben és környékén bizonyítottan csak a Bél-kőn fordul elő az Onosma visianii.

Boros Ádám 1934-ben keresi fel az Upponyi-szorost és alaposan bejárja annak mindkét oldalát, tovább növelve az eddig ismertté vált fajok listáját: Erysimum odoratum var. bükkense, Sorbus danubialis („S. aria subsp. Jávorkae”, 1960-ban „S. Soói” néven), Hypericum elegans, Poa badensis (Boros 1934) és a település útja mentén gyűjti a Conringia orientalist.

Soó Rezső az „Előmunkálatok a Bükkhegység és környéke flórájához” c. művében össze- 
foglalja az eddigi eredményeket (Soó 1943), feldolgozva Budai jegyzeteit, revideálva herbáriumi anyagának egy részét is. Ekkor kerül közlésre számos csak Budai József által megtalált, de nem publikált adat Uppony és Bánhorváti települések határából (pl. Adoxa moschatellina, Asyneuma canescens, Geranium lucidum), valamint Budai és Boros Ádám (BoRos 1934) által is megtalált érdekes növény előfordulása az Upponyi-szorosból: Erysimum odoratum (E. pannonicum var. bükkense néven), Minuartia setacea, Spiraea media, Waldsteinia geoides.

Boros 1960-ban újra felkeresi a helyet és Budait követően Ő is megtalálja az Asyneuma canescens-t. Ekkor már kisebb kitérőt is tesz a környéken Sajómercse és Bánhorváti irányába. A sajómercsei Magas-hegyen megtalálja a Chamaecytisus albus-t és az Echium maculatumot (Boros 1960).

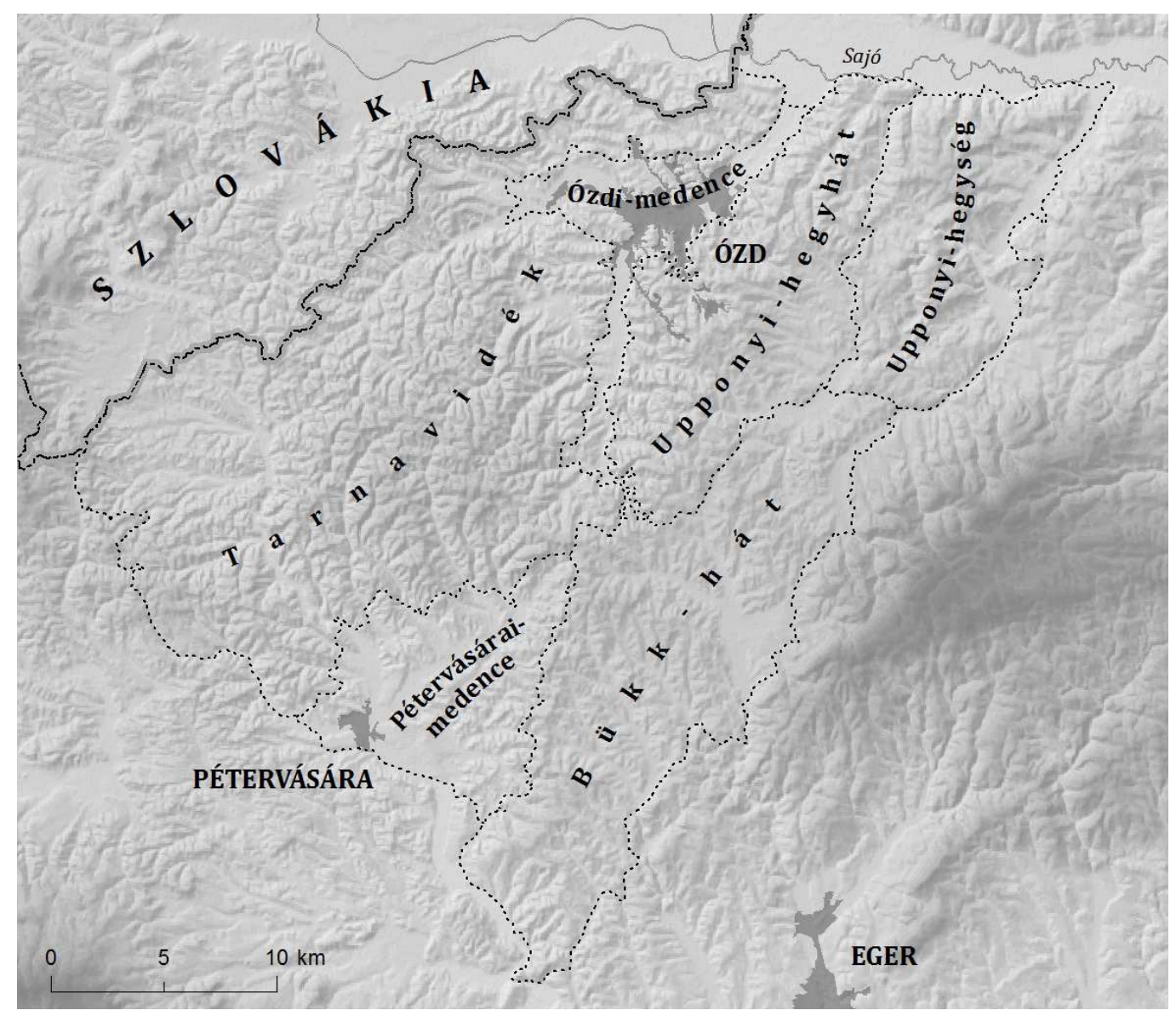

1. ábra A kutatási terület kistájak szerinti felosztása (HEVESI 1978, DöVÉNYI 2010 szerint módosítva)

Fig. 1 Microregions of the study area

Az 1990-es évekig a terület „feledésbe” merül, amíg Vojtkó András el nem kezdi térképezni az Upponyi-szorost és szűkebb környezetét. Ennek eredményeit 1994-ben és 1995ben publikálja (VоJтKó 1994, 1995). 1995-ös cikkében bemutatásra kerülnek a terület vegetációtípusai és számos új növényfajjal bővíti a szurdok és környéke flóralistáját: Adonis vernalis, Cephalanthera rubra, Clematis recta, Helleborus purpurascens, Iris pumila, Jovibarba globifera (Jovibarba hirta néven), Lunaria rediviva, Neottia nidus-avis, Onosma arenaria subsp. tuberculata, Pulsatilla grandis.

Közben a hegység Upponyi-rögön kívül eső részeinek is elkezdődik a kutatása, amelynek 
eredményeiről SULYOK \& SCHMOTZER (1999) számol be, jelentősen bővítve a hegység flóralistáját a félszáraz gyepekre és lápokra vonatkozó új adatokkal. VojTKó (1999) az Asperula rumelica-t közli az Upponyi-szorosból.

A Bükk hegység flóramúve (VojTKó 2001) az Upponyi-rögre és Borsodbóta környékére újabb adatokat is tartalmaz, pl. Diplotaxis muralis, Stipa pulcherrima. Az ezredforduló után is folytatódik a hegység feltárása, amely a flóra további megismerésére és a teljes terület vegetációtérképezésére irányul. Ennek részeredményei már publikálásra kerültek (BERÁNEK 2007, 2008, SULYOK 2011).

Az eddigi adatok ismeretében elmondható, hogy a régióban két montán hatás alatt álló terület található (2. ábra), általánosságban a Tarnavidék, valamint az Upponyi-szoros. Utóbbi jégkorszaki reliktumoknak is otthont ad (pl. Saxifraga paniculata). A Tarnavidék hüvös völgyeiben nem ritka a Cardamine glanduligera, amely a homokkővidéken egy többé-kevésbé összefüggő sávban - C-alakban - követi a magasabb dombokat a Medvestől Arlón át egészen Hangonyig (azonban érdekes módon a leleszi Nagy-völgy montán hatást tükröző bükköseiből már hiányzik). A Cardamine mellett gyakori még a Primula elatior, de más montán fajok is előfordulnak, amelyek a homokkő alapkőzeten fekvő völgyi extrazonális bükkösök nagyon jó vízmegtartó képességét jelzik. Ezek között vannak országos szinten is ritka fajok, mint az Aruncus dioicus, az Equisetum hyemale, az E. sylvaticum, a Petasites albus és a Phegopteris connectilis, vagy az újonnan felfedezett Epipogium aphyllum.

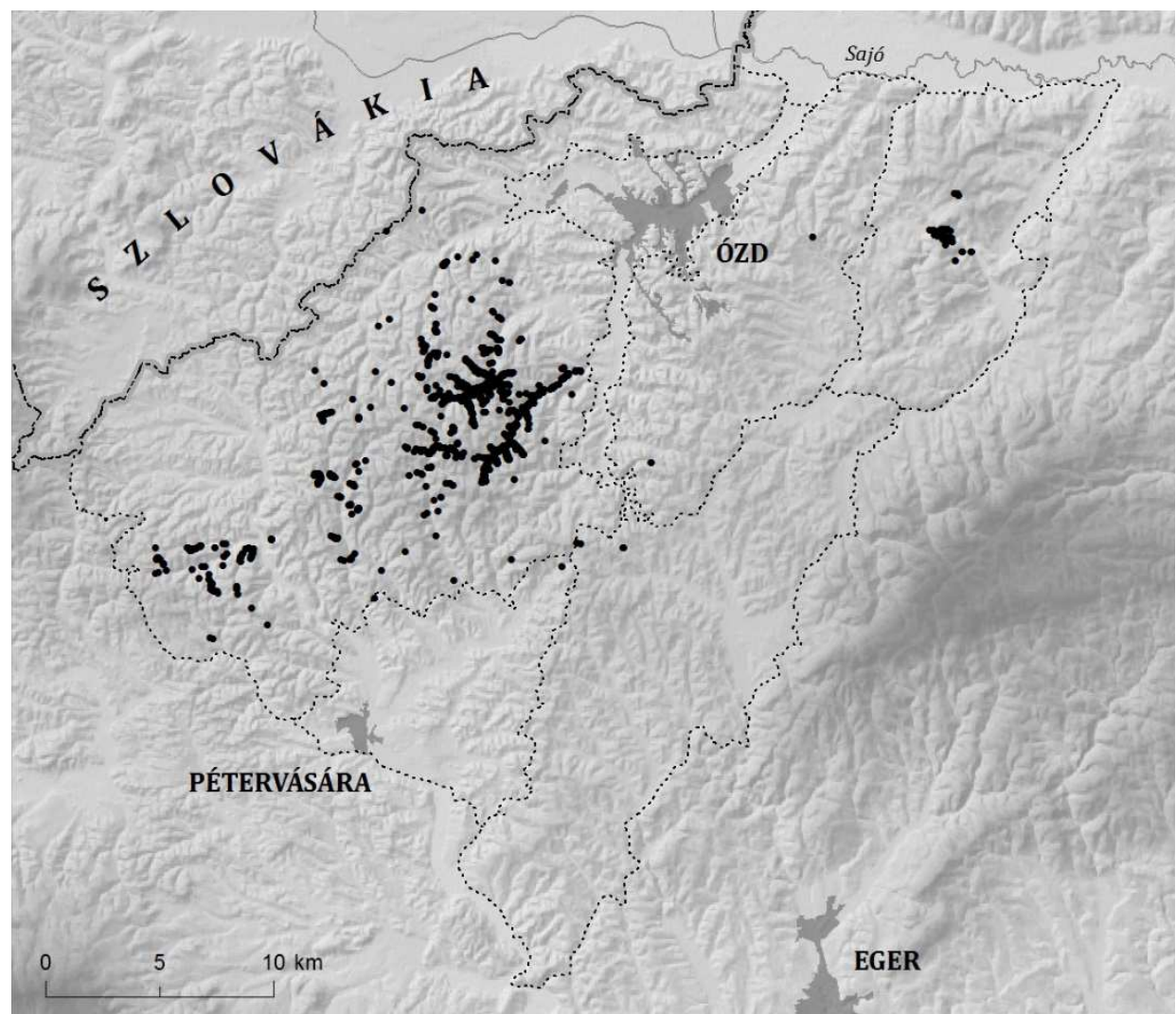

2. ábra Néhány montán faj elterjedése a kutatási területen

Fig. 2 Distribution of some montane element on the study area

(Aruncus dioicus, Asplenium scolopendrium, Cardamine glanduligera, Equisetum hyemale, Equisetum sylvaticum, Lunaria rediviva, Petasites albus, Polystichum aculeatum, Primula elatior, Saxifraga paniculata, Sesleria hungarica) 


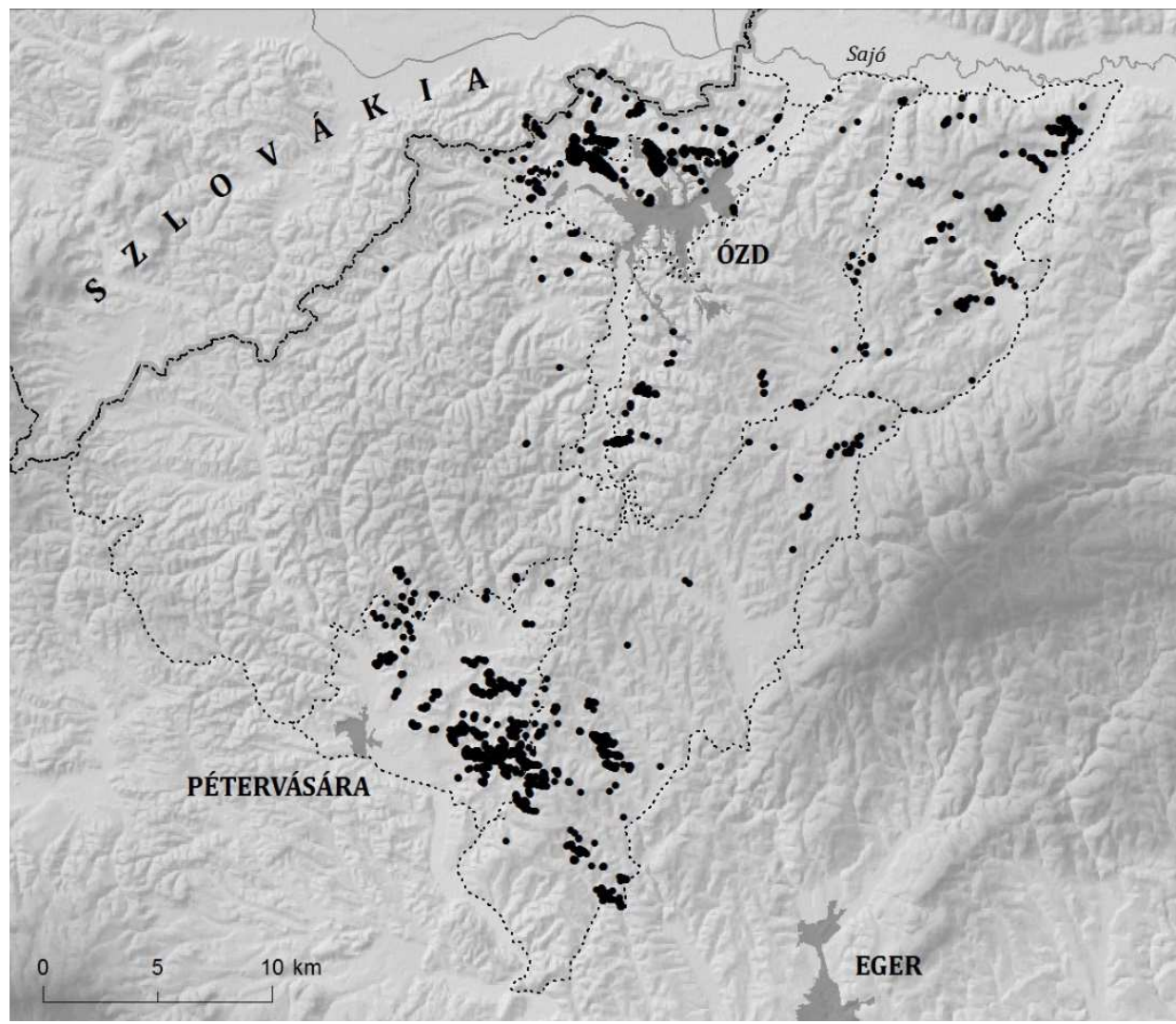

3. ábra Erdőssztyep fajok elterjedése a kutatási területen

Fig. 3 Distribution of some forest-steppe element on the study area

(Adonis vernalis, Anemone sylvestris, Cerasus fruticosa, Echium maculatum, Inula germanica, Inula hirta, Iris aphylla subsp. hungarica, Stipa tirsa, Thalictrum minus, Thlaspi jankae)

Hasonlóan érdekes az Északi-középhegység déli előterében előforduló erdőssztyep fajok megjelenése a Mátra és a Bükk északi oldalának dombvidékein. Ezen fajok esetében két beáramlási útvonal mutatható ki, a Sajó-völgy és a Bükk-Mátra között húzódó Tarna-völgy (3. ábra). A kistájak közül a Pétervásárai-medencében a legerősebb az erdőssztyep hatás, ahol kisebb erdőssztyep refúgiumok is fennmaradtak, számos a dombvidéken ritka vagy unikális fajt őrizve, mint például a Phlomis tuberosa, a Thlaspi jankae, a Hesperis sylvestris, vagy a Stipa tirsa. A medencére és annak peremére korlátozódik még néhány növényfaj elterjedése, mint például a Corothamnus procumbens, a Globularia punctata, a Cephalaria transsylvanica és a Scabiosa canescens, a fafajok közül a Fraxinus ornus, bár legutóbbinak Ózd környékéről is van néhány recens adata (MolNÁR \& CZÚCZ 2009).

A Tarnavidék déli részén vannak az ismert adatai a Potentilla micrantha-nak (Bükkszenterzsébet-Pétervására-Tarnalelesz), melyek a növény hazai elterjedésének legkeletibb előfordulásai közé tartoznak (SRAMKó et al. 2003, VojTKó 2008, BARTHA et al. 2015). Pontos elterjedésének a megállapítása azonban még további vizsgálatokat igényel.

Értékes fajokat őriznek a terület kisebb kiterjedésű láprétjei: Blysmus compressus, Carex flava, C. nigra, C. panicea, Dactylorhiza incarnata, D. majalis és hibridjük, Epipactis palustris, Eriophorum angustifolium és E. latifolium, Taraxacum palustre, Triglochin palustre, Valeriana dioica; valamint égerligetei - erdei forráslápjai: Cardamine amara, Carex appropinquata, $C$. paniculata, Epilobium roseum, Glyceria nemoralis, G. notata, Valerina dioica. De a néhol meg- 
maradt mocsárrétek - mocsári társulások is tartalmaznak még érdekesebb növényeket: Carex buekii, C. cespitosa, Myosotis caespitosa, Cirsium palustre. Nagyobb állományai maradtak fenn (patakok mentén) a tájegységi szinten szerencsére még nem ritka Dactylorhiza incarnata-nak vagy a Carex buekii-nek, bár a nedves élőhelyek építési törmelékkel való feltöltése települések közelében sajnos (a környéken is) terjedőben van.

Új fajok a Tarnavidékre: Adoxa moschatellina, Bifora radians, Carex appropinquata, Carex paniculata, Chamaecytisus virescens, Epipactis leptochila subsp. neglecta, Epipactis voethii, Epipogium aphyllum, Euphorbia glareosa, Glyceria nemoralis, Inula germanica, Luzula multiflora, Myosotis caespitosa, Orobanche arenaria, Phlomis tuberosa, Ribes rubrum var. rubrum, Rosa gizellae, Scilla kladnii, Silene dichotoma, Sisymbrium loeselii, Solanum villosum, Stipa tirsa, Taraxacum palustre, Tetragonolobus maritimus subsp. siliquosus, Thlaspi jankae, Waldsteinia geoides

Új fajok az Upponyi-hegyhátra és hegységre: Agrimonia procera, Alchemilla micans, Carlina acaulis, Cephalanthera $\times$ schulzei, Epipactis leptochila subsp. neglecta, Epipactis albensis, Epipactis purpurata, Euphorbia platyphyllos, Ferula sadleriana, Gagea bohemica, Inula germanica, Orobanche arenaria, Platanthera $\times$ hybrida, Rosa gizellae, Rumex confertus, Scilla kladnii, Sorbus zolyomii, Tetragonolobus maritimus subsp. siliquosus, Veronica dillenii

\title{
Anyag és módszer
}

A felsorolásban használt dűlőnevek alapját az M 1:10.000-es méretarányú EOV vetületi rendszerű topográfiai térképek, a külterületi kataszteri térképek, a katonai felmérések térképei, turistatérképek, erdészeti térképek és a Heves megyei helységnévtár névanyaga képezi, kiegészítve származtatott és saját helyi gyüjtésekkel. Utóbbiak esetében a helynév után megadjuk annak elhelyezkedését a topográfiai térképen szereplő legközelebbi földrajzi névhez viszonyítva. A taxonok sorszámozása és nevezéktana az Új magyar füvészkönyvet (KIRÁLY 2009) követi. A lelőhelyekhez tartozó CEU-kódokat (KIRÁLY \& HoRvÁTH 2000) az adott faj után soroljuk föl. Az előfordulások felsorolásánál, ha több is egy adatközlőhöz tartozik, akkor a nevét az utolsó földrajzi név után tüntettük fel. Ha egy fajnévhez csak egyetlen adatközlő tartozik, akkor az összes adat tőle származik.

Az enumeráció összeállításánál a „Flóraatlasz” adatait csak korlátozott mértékben használtuk fel, mivel az ott szereplő adatok aggregáltsága miatt a pontos térbeli lokalitásuk sokszor nem beazonosítható, nem visszaellenőrizhető, így az általunk gyújtött részletes adatokkal nem összevethető. Számos, a flóratérképezés során gyüjtött saját adatunk most kerül részletes publikálásra és megállapítottuk, hogy a „Flóraatlaszban” a lokalitáshoz megadott községhatárok sem mindig egyeznek meg a valósággal. Ezeket most pontosítjuk. Ennek ellenére egyes, regionális szempontból fontos fajok esetében megemlítjük a „Flóraatlasz”-ban szereplő adatokat is. A herbáriumi gyújtések az MTM Növénytárában kerültek elhelyezésre.

\author{
A kistájak megnevezésekor az alábbi rövidítéseket alkalmaztuk: \\ Bh: Bükk-hát \\ Tv: Tarnavidék \\ Óm: Ózdi-medence \\ Uh: Upponyi-hegyhát \\ Pm: Pétervásárai-medence \\ Uhg: Upponyi-hegység
}

Adatközlők:

BÁ: Beránek Ábel

SJ: Sulyok József

MVA: Molnár V. Attila

PF: Pifkó Dániel

SL: Somlyay Lajos

SM: Sulyok Máté

SA: Schmotzer András

Gyüitemények:

BP: MTM Növénytár

EGR: Eszterházy Károly Egyetem 


\section{Enumeráció}

5. Lycopodium clavatum L. - Az utóbbi évtized melegedő nyarai miatt az állományok visz-

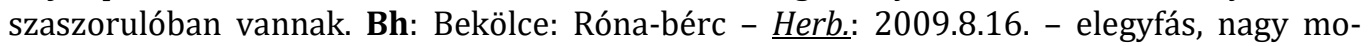
haborítású borókásban; Valószínűleg erre az előfordulásra vonatkozik BENEDEK \& ZAY (1987) Bekölce: Szilakszó adata; Tv: Borsodszentgyörgy: Közép-orom - Herb.: 2007.7.15. idősebb lucos szélén néhány ponton; Hangony: Kántor-verő - a Szajna-fő délnyugati gerince, nagy mohaborítású mészkerülő bükkösben; Uh: Borsodnádasd: Vásáros-úti-völgy - lucos nyíltabb részein (BÁ). CEU: [7887.1], [7887.4], [7987.2].

8. Equisetum telmateia Ehrh. - Égerligetek, üde völgytalpak erdőszéli magaskórósainak növénye. Tv: Arló: Zsá-völgy (SJ); Borsodnádasd: Karácsonylova (BÁ); Borsodszentgyörgy: Nagy-Járnok-völgy, Teresznek-far-tető (SJ); Hangony: Biriny-völgy, Halyág-bérc; Istenmezeje: Hagymás-völgy, Katus-gödör (BÁ); Váraszó: Herceges (SJ); Óm: Borsodnádasd: Karácsonylova-völgy (BÁ); Uh: Arló: Asszony-berki, Szohony-völgy (SJ); Borsodnádasd: Vásáros-úti-völgy (BÁ). CEU: [7786.4], [7886.4], [7887.1], [7887.2], [7887.3], [7887.4], [7986.1]. 10. Equisetum sylvaticum L. - Üde völgyalji erdőkben ritka. Bh: Bekölce: Róna-bérc -

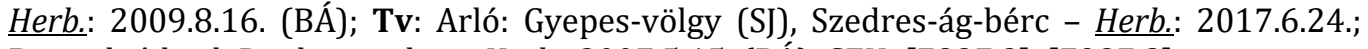
Borsodnádasd: Dögkert-völgy - $\underline{\text { Herb.: }}$ 2007.5.15. (BÁ). CEU: [7887.3], [7987.2].

12. Equisetum fluviatile L. em. Ehrh. - Tv: Domaháza: Son-torok - kis kiterjedésű forráslápban állományalkotó (SJ). CEU: [7886.2].

14. Equisetum ramosissimum Desf. - Homokkő málladékon kialakult száraz, néhol bolygatott gyepek növénye. Tv: Bükkszenterzsébet: Erzsébeti-völgy - Herb.: 2007.6.17.; Domaháza: Asztag-völgy-hegy (BÁ); Ózd: Meleg-oldal (SJ); Pétervására: Lyukas-kő-hegy (BÁ); Pm: Tarnalelesz: Bokor-völgy (SJ); Váraszó: Szőlő-megi-hegy (BÁ). CEU: [7787.3], [7886.2], [7986.2], [7986.3], [7987.1].

15. Equisetum hyemale L. - Völgytalpak üde, montán jellegű bükköseiben szórványos. Tv: Arló: Lencsényi-tető - a Kis-Poporótól északra eső 411,7 m-es hegy; Borsodszentgyörgy: Teresznek-far-tető (SI); Istenmezeje: Hagymás-völgy (BÁ). CEU: [7887.1], [7986.1].

17. Ophioglossum vulgatum L. - Bh: Bükkmogyorósd: Csepegő-forrás - kiszáradó magassásosban 70 tő (SJ). CEU: [7888.3].

28. Pteridium aquilinum (L.) Kuhn - Mészkerülő bükkösök fényben gazdagabb részein, elsősorban erdőgazdasági utak mentén. Tv: Arló: Gyöngy-ág-bérc, Pap-kút-alsó-bérc; Domaháza: Aszaló-Bikk, Ölyves-völgy, Zálogos; Istenmezeje: Nagy-Rákos, Rákos-lápa, Rákoslápa-bérc; Váraszó: Lugzós-bérc, Váraszói-völgy (BÁ). CEU: [7886.2], [7886.3], [7886.4], [7887.3], [7985.2], [7986.1].

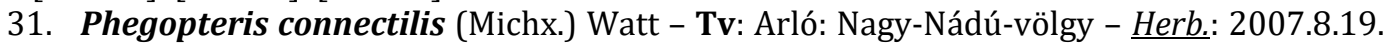
- szurdokerdőben kb. 30 hajtás, köztük számos spóratartóval rendelkező is; Tarnalelesz: Pataj-völgy - a völgy aljának közelében, kisavanyodott homokköves talajon, nehezen megközelíthető, suvadásos helyen 7 hajtás. A növény igen ritka a Bükkben (BoRos 1922, 1938, VojTKó 1999, 2001, 2008) és ritka a Mátrában is, ahol néhol homokkő alapkőzeten is előfordul (SRAmKó et al. 2003, SRAmKó et al. 2008). (BÁ). CEU: [7886.4], [7887.3].

32. Asplenium scolopendrium L. - A „Flóraatlasz”-ban a 7788.4-es kvadrátból Vojtkó Andrásnak Uppony községhatárából (1996) van adata [1]. Uhg: Dédestapolcsány: Nagy-erdő, a víztározó melletti törmeléklejtő erdőben 95 egyed. (SJ). CEU: [7788.4].

35. Asplenium septentrionale (L.) Hoffm. - Mészkerülő tölgyesek sziklakibúvásain. Uhg: Dédestapolcsány: Halabuka-tető (SJ); Nekézseny: Bánya-oldal (BÁ). CEU: [7888.2].

39. Asplenium adiantum-nigrum L. - Árnyasabb homokkősziklák, sziklás erdők növénye. Pétervására és Tarnalelesz környékéről - közelebbi helymegjelölés nélkül - a faj már említésre kerül SEREGÉLYES in FARKAS (1999) „Magyarország védett növényei”-ben is. Tv: Bükk- 


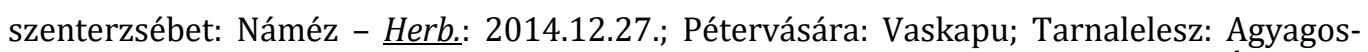
hegyes, Burja-hegyese, Kosaras-lápa-fő, Pataj-verő - Herb.: 2007.10.21. (BÁ). CEU: [7886.4], [7986.2], [7986.3].

40. Asplenium ruta-muraria L. - Homokkő sziklahasadékok, árnyasabb sziklák növénye. A homokkővidéken ritka. Uhg: Nekézseny: Bánya-oldal - itt mészkősziklán; Tv: Istenmezeje: Kőhártya-tető; Tarnalelesz: Kosaras-lápa-fő, Pataji-far (BÁ). CEU: [7886.4], [7888.2], [7986.1].

46. Gymnocarpium dryopteris (L.) Newman - Üdébb mészkerülő bükkösök növénye. Bh: Bekölce: Nagy-berek; Borsodnádasd: Bánya-fölött; Uhg: Bánhorváti: Egres-völgy - Herb: 2016.5.25.; Dédestapolcsány: Balta-tető (BÁ), Nagy-erdő (SJ), Rádincs-völgy (BÁ); Sajóvelezd: Mile-bérc; Uppony: Vízköz; Tv: Arló: Gyepes-völgy (SJ), Nagy-Nádú-völgy; Borsodszentgyörgy: Nagy-Kőte-völgy (BÁ), Vadberke (SJ); Domaháza: Tamás-Bükk; Hangony: Szoros-völgy; Istenmezeje: Hagymás-völgy, Hegyes-kukucsa, Rák - Herb.: 2007.7.17. (BÁ), Völgy-árnyék-bérc (SJ); Szilaspogony: Csurgó; Váraszó: Csókás-hegy; Óm: Borsodnádasd: Karácsonylova-völgy, Uh: Borsodnádasd: Csiterkötő-tető (BÁ). CEU: [7787.3], [7788.4], [7885.4], [7886.2], [7886.3], [7886.4], [7887.1], [7887.3], [7887.4], [7888.2], [7985.2], [7986.1], [7987.2].

47. Gymnocarpium robertianum (Hoffm.) Newman - Szurdokerdő homokkőfalán és az alatta lévő málladékon. Hasonló élőhelyről jelzi CSIKY \& KóBOR (2001) is Bárna mellől. SULYOK \& SchMOTZER (1999) cikkében az Arló: Keserű-orom [7887.3] lelőhellyel közölt adat valójában G. dryopteris. A „Flóraatlasz”-ban Vojtkó Andrásnak Uppony és Istenmezeje községhatárából van adata. A faj a Bükkben szórványos (VoJTKó 2001), az Upponyi-hegységből ZólYOMI (1928) közölte, míg a Mátrából MolnáR et al. (2019). Tv: Járdánháza: Cseterna Herb.: 2007.7.14. (BÁ). CEU: [7887.3].

51. Polystichum aculeatum (L.) Roth - Elsősorban szurdokerdők és völgyközeli bükkösök növénye, de előfordul egyéb üde, árnyas erdőkben, lucosokban és akácos szurdokokban is. Főleg a homokkővölgyek felső, már némileg beszűkülő szakaszán. A Tarnavidéken elterjedt, bár előfordulásai legtöbbször néhány tőre korlátozódnak. Uhg: Dédestapolcsány: Li-

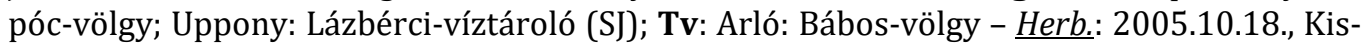
Poporó, Nagy-Nádú-völgy; Borsodszentgyörgy: Üsnök-völgy; Bükkszenterzsébet: Hasásza, Szappan-kő; Domaháza: Ölyves-völgy, Zálogos-gödör; Hangony: Disznóverem; Istenmezeje: Alsó-Szerpatak-gödre, Csernyus, Felső-Kajra-völgy, Görbe-fő, Hagymás-völgy, Nyírjes-völgy - Herb.: 2010.5.9., Szer-patak-orom; Járdánháza: Cseterna; Kissikátor: Hintós-tető; Pétervására: Lajos-patak-árnyék, Lajos-patak-völgy; Szilaspogony: Béka-fő (BÁ); Tarnalelesz: Kosaras-lápa-fő (SJ), Ordas-kő (BÁ), Pataji-far (SJ), Pénzes-hegy; Váraszó: Hosszú-ágy, Len-ág, Lugzós-bérc, Nagy-Lugzós, Zelemér (BÁ); Pm: Szentdomonkos: Nyárjas-lápa (SJ); Uh: Borsodbóta: Bükkfó-erdő (BÁ). CEU: [7786.4], [7788.3], [7788.4], [7886.2], [7886.3], [7886.4], [7887.1], [7887.3], [7985.2], [7986.1], [7986.2], [7987.1].

56. Dryopteris carthusiana (Vill.) H.P. Fuchs - Bükkösök, gyertyánelegyes erdők, telepített fenyvesek és égerligetek növénye. Bh: Bekölce: Jó-Berke-erdő (SJ), Nagy-berek, Róna-bérc (BÁ), Szilakszó (SJ); Borsodnádasd: Bánya-fölött (BÁ), Bükk-tető; Uhg: Bánhorváti: Bárcioldal, Éles-kő-tető - az Éles-kőtől délkeletre húzódó 289,7 m-es hegy; Dédestapolcsány: Bender-bérc - a Vízköztől délre található 423,2 m-es hegy, Lipóc, Lipóc-völgy, Malomhegyese, Nagy-árnyék, Nagy-erdő; Nekézseny: Upponyi Közép-bérc; Sáta: Hosszak és Kéritó; Uppony: Bender-bérc, Csernely-patak-völgye, Kalica-tető, Lázbérci-víztároló, Vízköz; Tv: Arló: Gyepes, Kerek-hegy - a Pajta-főtől délkeletre eső kis hegy, Kis-Remete, Nagy-Poporó, Remete-völgy, Szúnyogos (SJ), Vajda-vár; Borsodnádasd: Bán-berke, Kört-völgy - a Körtvölgye-forrás völgye, Nagy-Ormos-hegy; Borsodszentgyörgy: Csanálos-völgy - $\underline{\text { Herb.: }}$ 2002.9.18. (BÁ), Nagy-Kőte (SJ); Cered: Hangya-lapos; Domaháza: Nagy-Szegeggye (BÁ), Nyárjasság, Sípós-árnyék, Tamás-völgy, Togonya, Tó-völgye-patak (SJ); Hangony: Birinyvölgy, Vizes-völgy-orom; Istenmezeje: Felső-Kajra-völgy, Görbe-fő, Gyepü-lápa-laposa, 
Hagymás-völgy - Herb.: 2008.6.1., Hegyes-kukucsa, Rákos-völgy; Pétervására: Lajos-patakárnyék, Lajos-patak-völgy (BÁ); Sajópüspöki: Kanizsa-tető; Szentdomonkos: Csókás (SJ); Szilaspogony: Kása-völgy - a Kása-berektől nyugatra eső völgy; Tarnalelesz: Sarkály-hegye (BÁ); Váraszó: Csókás-hegy, Verő-lápa, Zelemér (SJ); Pm: Bükkszenterzsébet: Szőlő-megihegy; Uh: Borsodbóta: Bótai-tető - a Bótai-völgytől nyugatra eső 393,9 m-es hegy, Bótaivölgy; Ózd: Bótai-tető (BÁ). CEU: [7786.4], [7788.1], [7788.3], [7788.4], [7885.4], [7886.1], [7886.2], [7886.3], [7886.4], [7887.1], [7887.3], [7888.1], [7888.2], [7985.2], [7986.1], [7986.2], [7987.1], [7987.2].

57. Dryopteris dilatata (Hoffm.) A. Gray - Üde bükkösök, égerligetek és lucosok növénye.

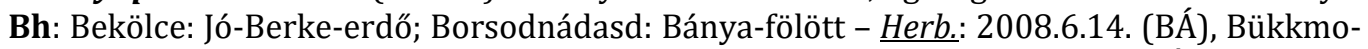
gyorósd: Alsó-sűrű-lápa; Szilvásvárad: Egres-völgy; Uhg: Dédestapolcsány: Éger-alja - a Dédestapolcsányból Nekézsenybe vezető közút völgye, Malom-hegyese; Nagybarca: Barcaioldal; Nekézseny: Hármas-határ; Sáta: Hosszak és Kéri-tó; Uppony: Bender-bérc; Tv: Arló: Gyepes-völgy, Nagy-Poporó, Remete-völgy (SJ); Domaháza: Szekeres-Bükk - $\underline{\text { Herb.: }}$ 2009.8.1. (BÁ), Váraszó: Herceges; Uh: Arló: Macó-bérc (SJ). CEU: [7788.4], [7789.3], [7886.1], [7886.4], [7887.3], [7887.4], [7888.1], [7888.2], [7888.3], [7987.2].

58. Dryopteris expansa (C. Presl) Fraser-Jenk. - Üde bükkösökben, többnyire idős bükkök tövében, ritkábban útrézsüben. Uhg: Bánhorváti: Bárci-oldal; Dédestapolcsány: Nagy-erdő; Uppony: Dedevár, Kalica-tető; Tv: Arló: Gyepes-völgy, Kerek-hegy, Nagy-Poporó; Istenmezeje: Völgy-árnyék-bérc; Szentdomonkos: Hosszú-völgy-dűlő; Váraszó: Csókás-hegy (SI);

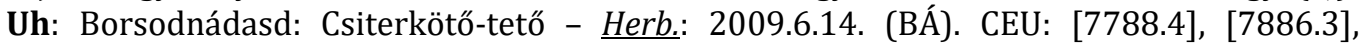
[7886.4], [7887.3], [7887.4], [7888.2], [7987.1].

128. Quercus robur L. - Idős hagyásfái völgyalji erdőszéleken. A tarnaleleszi Nagy-völgyből már SuBA (1969) is említi. Tv: Tarnalelesz: Nagy-völgy - $\underline{\text { Herb. }}$ : 2009.6.28., Vállós-puszta Herb.: 2009.6.14. (BÁ); Váraszó: Zelemér (SJ). CEU: [7886.4].

133. Ulmus glabra Huds. - Üde bükkösök és szurdokerdők ritkább elegyfája. Tv: Arló: KisNádú-bérc - Herb.: 2011.8.30., Kis-Nádú-völgy, Nagy-Poporó; Cered: Szilas-patak-völgye Herb.: 2012.5.20.; Istenmezeje: Görbe-fö, Rákos-völgy; Tarnalelesz: Pataj-völgy; Váraszó:

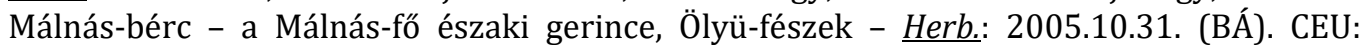
[7885.4], [7886.4], [7887.1], [7887.3], [7985.2], [7986.1].

134. Ulmus minor Mill. - Tv: Hangony: Hilye-kő - Herb.: 2015.9.22. - Molyhos tölgyesben; Pm: Erdőkövesd: Kis-völgy-far - Herb.: 2011.11.1 - Akácültetvény szélén. (BÁ). CEU: [7787.3], [7986.2].

149. Parietaria officinalis L. - A szoros északi oldalában, sziklaerdőben. Uhg: Uppony: Upponyi-szoros - Herb.: 2009.5.15. (BÁ). CEU: [7788.4].

157. Asarum europaeum L. - Bükkösökben és gyertyános-tölgyesekben szórványos előfordulású. Uhg: Bánhorváti: Bárci-oldal, Éles-kő, Éles-kő-tető; Dédestapolcsány: Derennekvölgy, Lázbérci-víztároló, Lipóc, Lipóc-völgy, Malom-hegyese, Nagy-erdő, Sár-oldal; Nekézseny: Hármas-határ-lápa - a Hármas-határ nyugatra lefutó nagyobb, északi völgye; Sáta: Csernely-patak-völgye; Uppony: Bender-oldal, Csernely-patak-völgye, Dedevár, Eszkálatető, Lázbérci-víztároló (SJ), Upponyi-szoros, Vízköz (BÁ); Tv: Arló: Géz-völgy, Gyepes, Gyepes-völgy, Kis-Poporó, Nagy-barlang-völgy, Nagy-Poporó, Palina-völgy, Szedres-ágbérc, Szúnyogos (SJ), Veres-csurgó-lápa (BÁ), Vészverés-bérc - a Vészverés-csúcs északi 388,8 m-es gerince, Vészverés-csúcs, Vizes-lápa-bérc; Borsodnádasd: Fajdás-völgy; Borsodszentgyörgy: Palina-völgy, Sása-lápa, Vizes-völgy; Hangony: Mogyorós-verő, Renget, Vizes-völgy-fő; Istenmezeje: Tamás telke-völgy; Kissikátor: Hintós-tető, Két-bérc, Tiszta-tető - a Tiszta-lápától északra eső 326,4 m-es hegy (SJ); Ózd: Harmaci-völgy-fő - a Harmacivölgy végében lévő 299,9 m-es hegy az országhatáron (BÁ); Sajópüspöki: Kanizsa-tető, Lapis-fő - a Lapistól nyugatra eső hegy az országhatáron, Szőlő-tető; Váraszó: Herceges, Kenyér-domb (SJ), Kis-Ves-völgy (BÁ), Szénégető-hegyese, Zelemér (SJ); Óm: Borsodnádasd: 
Szalinca (SJ). CEU: [7786.4], [7787.1], [7787.2], [7788.1], [7788.4], [7886.2], [7886.3], [7886.4], [7887.1], [7887.3], [7888.2], [7986.2].

197. Rumex confertus Willd. - A faj elterjedésének súlypontja az Alföldre esik a Tisza mentére (BARTHA et al. 2015). Az Upponyi-hegységhez legközelebb a Sajó-völgyben fordul elő, amelyről már Budai József hírt adott (BuDAI 1914). A közeli Tardonai-dombságban pedig Boros Ádám találja meg 1931. 6. 21-én (Boros 1931). Új az Upponyi-hegységre. Uhg: Dédestapolcsány: Kerek-domb - félszáraz gyepben 4 egyed (SJ). CEU: [7888.2].

255. Salsola kali L. subsp. ruthenica (Iljin) Soó - Nyílt száraz gyepben ritka. LENGYEL (1906) említi korábbi adatait a Tarnavidékről Váraszó, Erdőkövesd és Istenmezeje határából. Pm: Tarnalelesz: Babar-völgy - $\underline{\text { Herb.: }}$ 2008.8.30. (BÁ). CEU: [7987.1].

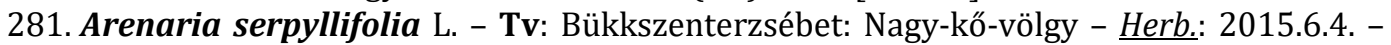
száraz gyepben gyakori (BÁ). CEU: [7986.2].

285. Minuartia setacea (Thuill.) Hayek - Homokkő- és mészkősziklagyepben szórványos. Uhg: Uppony: Eszkála-tető, Macskás. Az Upponyi-hegységből eddig csak az Upponyiszorosból volt ismert (BoROs 1934, VojTKó 1995, 2001). Tv: Tarnalelesz: Peskő-tető - $\underline{\text { Herb. }}$ : 2008.5.16. - KovÁCS \& MÁTHÉ (1964) adatának megerősítése (BÁ). CEU: [7788.4], [7986.2].

323. Scleranthus annuus L. - Tv: Hangony: Elekes - Herb.: 2016.6.5. - felhagyott szántón tömeges (BÁ). CEU: [7787.3].

335. Lychnis coronaria (L.) Desr. - Gyakori növény cseres- és gyertyánelegyes tölgyesekben, illetve ezek vágásterületein, valamint félszáraz gyepekben. Bh: Bekölce: Nagy-berek, Rónabérc (BÁ); Borsodnádasd: Láz; Hevesaranyos: Fitos (SJ); Tarnalelesz: Bihaj-ortás (BÁ); Tv: Arló: Babos-köz-orom, Kis-barlang-bérc - a Kis-barlang-völgytől délnyugatra eső 408,5 mes hegy, Közép-Poporó - a Kis-Poporótól délre eső 405,3 m-es hegy, Nádú-bérc, Nádú-bérctető, Nyír-völgy, Záré-tető; Borsodnádasd: Karácsonylova, Lapuhas; Borsodszentgyörgy: Kis-Benedek (SJ); Bükkszenterzsébet: Közép-Berek; Domaháza: Boronás-padosa, Bükk-tető (BÁ), Csúnya-fő, Fülek-vára (SJ), Kenderes, Kerek-Bükk (BÁ), Kis-Szegeggye-tető - a KisSzegeggye-völgytől nyugatra eső 355,5 m-es hegy, Máté-Bükk, Nyárjasság (SJ), Pácon-oldal - a Pácon-szúró fölötti, az országhatáron húzódó 346,5 méteres hegy (BÁ), Petyke-bérc, Répás-tető, Répás-verő, Répás-völgy (SJ), Szekeres-Bükk, Széles-Imola-völgy, Szilvásárnyéka, Szörnyü, Utas-árnyék, Zálogos-gödör; Hangony: Barát-völgy, Biriny-vár, Disznóverem (BÁ), Kis-berek-bérc (SJ), Kis-berek-fö, Kis-Golotka, Ortás-lápa-orom (BÁ), Petyke-bérc (SJ), Pogányvár, Szilakszó; Istenmezeje: Kis-erdő, Sárkány-kút (BÁ); Járdánháza: Cselényvölgy (SJ); Kissikátor: Hangony-völgy (BÁ), Macskás, Renget-verő, Répa-hegyese, Villáros (SJ); Pétervására: Alsó-Akol-völgy, Dudar-hegy, Gyupáros, Külső-hang-láza, Lyukas-kőhegy, Remete-vár, Vasas-út-verő, Vaskapu; Szentdomonkos: Ferenc-tető - a Ferenc-lápától délkeletre eső 362,5 m-es hegy; Tarnalelesz: Burja-hegyese, Henc-ortvány, Kőkút, Középbérc, Pataji-far, Pataj-verő, Tölgyes-tető - a Tölgyes-lápától északnyugatra eső 430,4 m-es hegy, Tüng, Tüng-hegye (BÁ); Váraszó: Fenekes, Fenekes-völgy (SJ), Kő-orom, Köves-út, Nagy-láz, Sárkány-kút (BÁ), Szénégető-hegyese (SJ), Tölgyes-tető; Zabar: Boronás-padosa, Csengős, Máté-Bükk, Ments-árnyék, Sárkány-kút (BÁ); Pm: Fedémes: Kútos-tető (SI); Tarnalelesz: Babar-tető (BÁ), Bolya-puszta (SJ); Váraszó: Gödrösi, Patakverej (BÁ); Uh: Arló: Bagó-lápa, Izra-völgy, Ladány-tető - a Ladány-tanyától északra eső 319,6 m-es hegy, Lőrinc-árnyéka, Macó-bérc, Szohony (SJ); Borsodnádasd: Budaberke, Csiterkötő - a Csiterkötő-tetőtől északkeletre eső 409,3 m-es gerinc, Mocsolyás-tető - a Mocsolyás-tanyától nyugatra eső 368 m-es hegy (BÁ); Csernely: Fazekas-oldal; Járdánháza: Szalinca (SJ). CEU: [7786.2], [7786.4], [7787.3], [7886.1], [7886.2], [7886.3], [7886.4], [7887.1], [7887.2], [7887.3], [7887.4], [7986.1], [7986.2], [7986.3], [7986.4], [7987.1], [7987.2], [7987.3].

337. Agrostemma githago L. - Tv: Borsodszentgyörgy: Vereses-tető, búzatábla szegélyében (BÁ); Pm: Szentdomonkos: A település belterületének szélén, a Domonkosi-völgy bejáratánál, parlagon (SJ). CEU: [7887.1], [7987.1]. 
346. Silene dichotoma Ehrh. - Pm: Pétervására: Alsó-lázi-dűlő - Herb.: 2009.7.19. - a feltárásfal alatti száraz gyepben gyakori (BÁ). CEU: [7986.4].

370. Dianthus deltoides L. - Üdébb mészkerülő gyepek és erdőszélek növénye. Bh: Bekölce: Róna-bérc (BÁ); Uhg: Bánhorváti: Bárci-oldal; Tv: Borsodnádasd: Kört-völgy, Szőlő-bérctető; Borsodszentgyörgy: Kalitka-völgy, Külső-Dóna, Vadberke (SJ); Bükkszenterzsébet: Közép-Berek, Málnás-fó; Domaháza: Aszaló-Bikk, Asztag-völgy, Asztag-völgy-bérc, Asztagvölgy-hegy, Csúnya-fő, Csurgó-bérc (BÁ), Hintós-árnyéka, Jós-Ortvány-tető (SJ), Kék-Ász-fő - a Kék-ász völgyének határmenti völgyfője, Kerek-Bükk, Körte-lápa - az Aszaló-Bikktől nyugatra eső völgy, Kovács-bérc - a Zsillyététől nyugatra lévő hegygerinc, Kovács-ortvány, Kovács-ortványa-fő, Mihály-tető - Mihály-homlokától északra eső 323,4 m-es hegy (BÁ), Miklós-fája (SJ), Nagy-völgy - Herb.: 2006.6.4., Nehák (BÁ), Répás-völgy, Son-torok (SJ), Széles-Imola-völgy, Zálogos, Zálogos-gödör, Zsellyéte; Erdőkövesd: Pajászó (BÁ); Hangony: Kortvány (SJ), Magas-hegy - $\underline{\text { Herb.: }}$ 2008.5.31., Mihászó-orom - a Mihászó északkeleti gerincének folytatásában lévő hegy, Tartalóca-puszta; Istenmezeje: Tamás telke-fő (BÁ); Járdánháza: Cselény-völgy, Hajag-tanya - a Hajag-tanya fölötti gyepes hegyoldal (SJ); Pétervására: Alsó-Akol-völgy, Lyukas-kő, Szénégető-völgy; Szentdomonkos: Ferenc-tető (BÁ); Váraszó: Kerek-dél (SJ), Nagy-Herceg (BÁ); Zabar: Völgy-verő-bérc (BÁ); Óm: Borsodnádasd: Szopon-völgy (SJ), Uh: Borsodnádasd: Budaberki-völgy (BÁ), Mocsolyás-völgy (SJ). CEU: [7787.3], [7788.4], [7886.1], [7886.2], [7886.3], [7886.4], [7887.1], [7887.3], [7887.4], [7986.1], [7986.2], [7986.3], [7987.1], [7987.2].

376. Dianthus collinus Waldst. et Kit. - Uhg: Bánhorváti: Bárci-oldal - enyhén mészkerülő száraz gyepben; Uh: Sajómercse: Körtvélyes - félszáraz szálkaperjés gyepben (SJ). CEU: [7788.3], [7888.2].

391. Nigella arvensis L. - Zavartabb száraz gyepekben szórványos. Tv: Domaháza: Mihálytető, Répás-völgy, Szörnyú (BÁ). CEU: [7886.1], [7886.2].

395. Actaea spicata L. - Üde bükkösök növénye. Óm: Borsodnádasd: Karácsonylova-völgy; Uh: Borsodbóta: Bükkfő-erdő; Borsodnádasd: Balatoni Cseres-bérc, Budaberki-völgy, Vásáros-úti-völgy (BÁ). CEU: [7788.3], [7887.3], [7887.4].

398. Aconitum anthora L. - A faj a régióban a Bükkben és a Mátrában nem túl ritka, viszont hiányzik a Tarnavidékről. Az Upponyi-hegységből az Upponyi-szorosból (BoRos 1934, VojTKó 1995, 2001) volt ismert. Ezen kívül az upponyi Három-kő-bércen gyüjtötte Szujkóné Lacza Júlia és Kováts Dezső 1982. 10. 5-én (BP). Uhg: Uppony: Dedevár (SJ), Eszkála-tető (BÁ). Mindkét lelőhelyen mészkövön lévő hárs-kőris sziklaerdőben. CEU: [7788.4].

399. Aconitum vulparia Rchb. - Az Upponyi-hegységben sziklai bükkösök, törmeléklejtő erdők, a Tarnavidéken üde bükkösök növénye. Uhg: Uppony: Eszkála-tető (BÁ), Lázbércivíztároló (SJ); Tv: Arló: Bábos-völgy - $\underline{\text { Herb.: }}$ 2005.10.18. (BÁ), Nádú-árnyék, Zár-fő - a Zárréttől keletre eső hegy; Borsodszentgyörgy: Vizes-völgy; Kissikátor: Kis-Benedek (SJ). CEU: [7788.4], [7886.2], [7887.1], [7887.3].

409. Anemone sylvestris L. - Sztyeprétek, félszáraz tollas szálkaperjés rétek, nyíltabb tölgyesek és erdőszélek ritkább növénye. Bh: Hevesaranyos: Nagy-lápa-tető (SJ); Uhg: Nekézseny: Avas-bérc - az Avas-völgytől délre eső 427,2 m-es hegy (BÁ); Sáta: Hosszak és Kéri-tó (SJ); Tv: Ózd: Sóskút-tető - a Sóskút-oldal fölötti 289,1 m-es hegy, Szenna-fő, Szenna-tető a Bükk-oldaltól keletre eső hegy, Zsófi János; Óm: Ózd: Borbás-hegy (BÁ), Szilas-tető - a Szil-tető vonulat keleti tagja a hétvégi-telkek mellett, Szil-tető (SJ), Tormás-tető - ÓzdSzenna városrésztől nyugatra eső 262,5 m-es hegy (BÁ); Pm: Fedémes: Kútos-tető; Hevesaranyos: Buja-hegy; Uh: Csernely: Borjúmáj (SJ). CEU: [7787.1], [7787.2], [7787.3], [7787.4], [7888.1], [7888.2], [7986.4], [7987.3].

414. Pulsatilla grandis Wender. - Sztyepréteken, Carex humilises szálkaperjés réteken, felnyíló tölgyesekben és erdőszéleken, sziklagyepekben fordul elő, helyenként jelentős egyedszámban. Bh: Bátor: Boza; Bekölce: Perekonya-bérc; Hevesaranyos: Gyilkos-tető; Uhg: Bor- 
sodbóta: Veres-tető; Dédestapolcsány: Éles-kő, Halabuka-tető, Köszörűs és varjas, Kukorica-föld (SJ), Nagy-hegy (BÁ), Szalacsi-kő; Nagyvisnyó: Somos-cserje (SJ); Nekézseny: Avasbérc (BÂ), Nagy-mál-tető, Szégyen-tető (SJ); Uppony: Cibróka (BÁ), Dedevár, Vízköz-szoros - a Csernely-patak kisebb szurdoka a Vízköz nyugati aljában; Tv: Borsodszentgyörgy: Kisasza-fő (SJ); Ózd: Sóskút-oldal, Sóskút-tető, Szenna-fő (BÁ); Sajópüspöki: Kőfeli (SJ), Szurdok (BÁ); Szentdomonkos: Kő-hegy (SI); Tarnalelesz: Peskő-tető (BÁ); Óm: Borsodnádasd: Szalinca; Ózd: Szilas-alja-hegyese, Szilas-tető, a Szil-tetőtől keletre húzódó két hegyen több ezer egyedet számláló populáció (SJ); Pm: Erdőkövesd: Öv-hegy (BÁ); Fedémes: Felsősóska-hely; Uh: Arló: Szohony; Borsodbóta: Őr-hegy; Csernely: Lukács Gergelyesse; Királd: Mazsúr, Ốr-tető - az Őr-hegytől délre eső 325,3 m-es hegy (SJ); Sajónémeti: Nagy-hegy (BÁ); Sajómercse: Körtvélyes, Nyúzó-völgy, Szarvaskút, Szörnyű-völgy (SJ). CEU: [7787.2], [7787.3], [7787.4], [7788.1], [7788.3], [7788.4], [7887.1], [7887.2], [7887.4], [7888.1], [7888.2], [7888.4], [7986.2], [7986.4], [7987.1], [7987.2], [7987.3], [7987.4].

416. Pulsatilla nigricans Störck - Az előző fajjal néha együtt is előfordul, de megtaláljuk még enyhén mészkerülő sztyepréteken, erdőszegélyekben is. Bh: Bükkmogyorósd: Eresztvény-bérc, Salamon-vár; Hevesaranyos: Gyilkos-tető, Vár-hegy; Sirok: Temető-felett; Uhg: Bánhorváti: Nagy-oldal; Borsodbóta: Vatos, Veres-domb; Sajóvelezd: Mazsor; Tv: Arló: Nádú-bérc; Borsodszentgyörgy: Kis-asza-fő (SJ), Vereses-tető (BÁ); Domaháza: Petyke-bérc (SJ); Hangony: Biriny-vár; Ózd: Kanizsa-tető; Tarnalelesz: Köves, Szarvas-kő; Váraszó: Kőorom, Nagy-Musák, Tó-hegyese (BÁ); Óm: Borsodnádasd: Szalinca (SJ); Ózd: Galyagos (BÁ), Szilas-tető (SJ); Pm: Erdőkövesd: Öv-hegy (BÁ); Fedémes: Árpaszó-hegy, Kútos-tető, Víg István-tető - a Berkenyés-verő nyugati gerince; Hevesaranyos: Buja-hegy, Kis-verő; Tarnalelesz: Lóhát-orom, Meszes (SJ); Váraszó: Hereg-vár, Ó-hegy, Öv-hegy (BÁ); Uh: Arló: Konnya-völgy, Pocsi-bérc - a Pocsi-orom nyugati gerince; Csernely: Kerek-völgy-tető; Járdánháza: Szalinca (SJ); Királd: Árok-oldal (BÁ); Sajómercse: Gógány, Körtvélyes, Szarvaskút (SJ). CEU: [7786.2], [7786.4], [7787.3], [7787.4], [7788.1], [7788.2], [7788.3], [7788.4], [7886.4], [7887.1], [7887.2], [7887.3], [7887.4], [7888.3], [7986.2], [7986.4], [7987.1], [7987.3], [8087.3].

418. Clematis integrifolia L. - A dombvidéken a faj kimondottan ritka, eddig csak a „Flóraatlaszból" ismert adata Domaháza mellett (Vojtkó András 2004 [1]). Óm: Ózd: Szilas-tető cserjésedő tollas szálkaperjés réten 30 egyed (SJ). CEU: [7787.3].

423. Clematis recta L. - Melegkedvelő tölgyesek szegélyében, ritkábban félszáraz gyepekben, cserjésekben. Uhg: Dédestapolcsány: Éles-kő-tető, Halabuka-tető, Lipóc, Nagy-hegyorom - a Nagy-hegy keleti gerince (SJ); Nekézseny: Avas-bérc (BÁ); Uppony: Fekete-kőtető; Uh: Sajóvelezd: Lapos-kő - a Vár-tetőtől délre lévő 297 m-es hegy (SJ). CEU: [7788.2], [7788.4], [7888.2].

424. Adonis vernalis L. - Sztyepréteken, néha félszáraz gyepekben helyenként tömeges. Bh: Bátor: Pusok-tető; Hevesaranyos: Berkenyés-verő, Dakó-hegye, Gyilkos-tető, Kis-bügör, Kopasz-orom, Körtélyes, Köszörüs, Nagy-lápa, Nagy-lápa-tető, Veres-hegy, Víg István-verő (SJ); Tv: Borsodszentgyörgy: Köpüs-kút-verő, Perpoka-fő; Bükkszenterzsébet: Dobogó-bérc - a Szappan-kőtől keletre eső 353,8 m-es gerinc, Erzsébeti-völgy, Közép-Berek, Nagy-kő, Nagy-kő-tető, Szappan-kő, Vár-magas; Hangony: Egres-oldal - az Egeres-völgytől az országhatár felé eső hegyoldal; Ózd: Cseres-oldal, Cseres-tető - a Veréb-ág 298,9 m-es völgyfője, Demeter-tető, Harmaci-völgy, Harmaci-völgy-fö, Kanizsa-tető (BÁ), Körtvészer-tető (SJ), Nagy-oldal, Nagy-verők (BÁ), Pásztor-kert-fő (SJ), Sóskút-oldal, Sóskút-tető, Vár-völgy, Zsófi János (BÁ); Sajópüspöki: Kőfeli (SJ); Tarnalelesz: Henc-ortvány; Óm: Ózd: Borbáshegy, Kő-tető - a Kő-alja fölötti hegy (BÁ), Szilas-alja-hegyese; Pm: Bükkszék: Csigdászó, Fenyves, Sirokaszó (SJ); Bükkszenterzsébet: Gödrösi; Erdőkövesd: Öv-hegy (BÁ); Fedémes: Kútos-tető, Meggyes-lápa - a Meggyes-oldaltól nyugatra eső völgy, Víg István-tető; Hevesaranyos: Barci-far, Bodony-árnyék, Dobogó-tető, Kaptás, Mocsolyás-rét, Sirokaszó, Siroka- 
szó-fő, Víg István-tető; Szentdomonkos: Tormás-hegy; Tarnalelesz: Csigdászó, Dancsok, Fingászó-hegy-orma, Lóhát-orom, Madarászó, Meszes, Tormás-hegy (SJ); Váraszó: Barca Tamás, File lova, Gödrösi, Hereg-vár, Patakverej, Szőlő-megi-hegy, Vagdaszó-bérc - a Vagdaszótól délkeletre eső gerinc (BÁ); Uh: Arló: Izra, Konnya-völgy, Ladány-tető, Macó-bérc, Szohony (SJ); Járdánháza: Mocsolyás (BÁ), Mocsolyás-völgy (SJ). CEU: [7787.1], [7787.2], [7787.3], [7787.4], [7788.1], [7887.1], [7887.2], [7887.4], [7986.2], [7986.4], [7987.1], [7987.3], [8087.1], [8087.2].

427. Adonis aestivalis L. - Uh: Csokvaomány: Nemecke-árnyék - Herb.: 2008.5.15. - búzavetés szegélyében (BÁ). CEU: [7888.1].

448. Ranunculus arvensis L. - Búzavetések szélén ritka. Tv: Hangony: Elekes; Bh: Balaton: Nagy-völgy - Herb.: 2008.6.14. (BÁ). CEU: [7787.3], [7887.4].

454. Ranunculus lanuginosus L. - Tv: Arló: Veres-csurgó-lápa - üde völgyalji bükkösben (BÁ). CEU: [7887.3].

462. Thalictrum minus L. - Száraz gyepekben, felnyíló erdőkben, erdőszegélyekben, mezsgyékben, útrézsűkben szórványos. Uhg: Bánhorváti: Lapác; Uppony: Eszkála-tető, Kalicatető, Upponyi-szoros; Tv: Borsodnádasd: Kerek-berek-fő; Hangony: Petyke-völgy; Óm: Borsodnádasd: Szalinca; Ózd: Szilas-tető; Pm: Hevesaranyos: Buja-hegy; Tarnalelesz: Lóhát-orom; Uh: Borsodbóta: Őr-hegy; Csernely: Alsó-Nyékes; Járdánháza: Szalinca; Sajóvelezd: Lapos-kő (SJ). CEU: [7786.4], [7787.3], [7788.2], [7788.3], [7788.4], [7887.3], [7887.4], [7888.1], [7986.4].

467,1. Paeonia officinalis L. - Kivadult, néhány töves virágzó állományai felhagyott gyümölcsösökben. Uh: Csokvaomány: Andornak; Sáta: Őr-hegy (BÁ). CEU: [7788.3], [7888.1].

495. Sisymbrium officinale (L.) Scop. - Pm: Bükkszenterzsébet: Káca-völgy - $\underline{\text { Herb.: }}$ 2007.6.17. - itató környéki taposott gyomtársulásban (BÁ). CEU: [7986.2].

497. Sisymbrium altissimum L. - Tv: Erdőkövesd: Cseres-tető. - $\underline{\text { Herb.: }}$ 2008.6.1. - homokkő-sziklagyepben (BÁ). CEU: [7986.3].

500. Sisymbrium loeselii L. - Az inkább alföldi elterjedésű faj a Sajó-völgyön keresztül éri el a dombvidéket és az itteni előfordulásai is a Sajóhoz esnek közel (SULYOK 2011). Új a Tarnavidékre. Óm: Ózd: Nagy-fák-alja - parkolónak kialakított feltöltés oldalában lévő száraz gyomtársulásban (SJ). CEU: [7787.4].

509. Erysimum repandum L. - Uh: Csokvaomány: Kis-Omány - $\underline{\text { Herb.: }}$ 2008.5.1. - felszaggatott gyepben szórványos (BÁ). CEU: [7888.1].

514. Erysimum odoratum Ehrh. - Melegkedvelő tölgyesekben, bokorerdőkben, ritkábban cseres-tölgyesekben, sziklagyepekben és köves sztyepréteken. Boros Ádám a var. bükkense taxont jelzi az Upponyi-szorosból (BoRos 1934), amelyet VojTKó (1995) is megerősít. Bh: Egercsehi: Magas-hegy; Uhg: Bánhorváti: Éles-kő-tető; Dédestapolcsány: Bender-bérc, Éles-

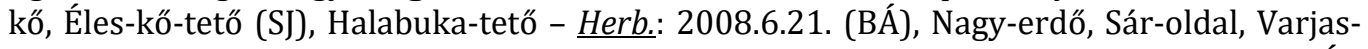
szőlő; Nekézseny: Zsellér-földek; Uppony: Bender-bérc, Dedevár (SJ), Eszkála-tető (BÁ), Fekete-kő-tető, Három-kő (SJ), Kalica-tető, Vízköz (BÁ), Zsellér-földek (SJ). CEU: [7788.4], [7888.2], [7987.2].

518. Hesperis sylvestris Crantz - A fajnak szórványos adatai ismertek a Bükkből (PRODÁN 1909, BUDAI 1914, Soó 1943, VojTKó 2001), a Mátrából és Salgótarján környékéről (Soó 1937, CSIKY 2004), valamint Bátor mellől (Erős Róbert 2003 [1]). Pm: Tarnalelesz: Lóhátorom - Kislevelű hársas zárt erdőssztyep-erdő maradványban, közel 50 egyed (SJ). CEU: [7986.4].

527. Rapistrum perenne (L.) All. - Száraz és félszáraz gyepekben szórványos. Bh: Csernely: Bazsik; Hevesaranyos: Ürge-hegy, Veres-hegy; Óm: Borsodnádasd: Szalinca; Pm: Fedémes: Aranyosi-oldal, Árpaszó-hegy, Bocoktó, Kútos-tető, Víg István-tető; Szentdomonkos: Tormás-hegy; Tarnalelesz: Fingászó-hegy-orma, Gásztászó, Kastály-legelő, Nagy-hegyesse; Uh: Arló: Csahó, Konnya, Ladány-tető, Szohony; Csernely: Ecetes-Tök, Nyékes-tető; Csokva- 
omány: Belterület, Páter-oldal; Sajómercse: Gógány, Mercse-patak-völgye (SJ). CEU: [7788.3], [7887.2], [7887.4], [7888.1], [7888.3], [7986.4], [7987.1], [7987.3].

536. Cardamine glanduligera 0 . Schwarz - Általában völgyközeli vagy meredek oldalakban lévő üde bükkösök, gyertyános-bükkösök és elegyetlen gyertyánosok növénye, de ritkán előfordul szurdokerdőkben és égerligetekben is. A korábban közölt előfordulási térképnél (BERÁNEK 2008) jóval elterjedtebb a homokkővidéken. Tv: Arló: Halonna-bérc, Lencsényitető, Nyilakó-völgy, Vészverés-bérc, Zár-fő; Borsodszentgyörgy: Eszkála-bérc, Felső-Ünök, Kémének-tető, Nagy-Kőte, Nagy-Kőte-völgy, Teresznek-far-tető (SJ); Istenmezeje: AlsóHagymás-bérc, Alsó-Kajra-völgy - Herb.: 2008.4.6., Alsó-Szerpatak-gödre, Békák-bérc Herb.: 2008.4.5., Evetes-ág, Felső-Kajra-völgy, Görbe-fő, Hagymás-völgy, Hollós-lápa, NagyCsengős, Száraz-ág - Herb.: 2008.4.6. (BÁ); Kissikátor: Felső-Vermes, Két-bérc, Pincés, Szeles-lápa (SJ); Váraszó: Cseres-lápa, Forró-kút-lápa, Herceges, Hosszú-rét, Kis-Ves, Kis-Vesvölgy, Lugzós-bérc, Nagy-Herceg, Nagy-Lugzós, Nagy-Ves-völgy, Szénégető-hegyese, Verőlápa, Zelemér (BÁ). CEU: [7886.2], [7886.3], [7886.4], [7887.1], [7887.3], [7986.1], [7986.2].

541. Cardamine amara L. - Égerligetek, forráslápok növénye, helyenként jelentős egyedszámban. Tv: Arló: Pap-kút, Pap-kút-alsó-bérc, Szedres-ág-völgy, Zár-rét (SJ); Borsodszent-

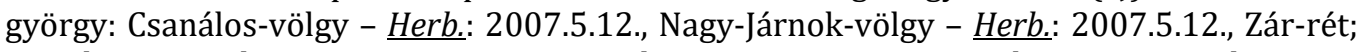
Cered: Hangya-lapos; Hangony: Biriny-völgy, Hangonyi-Renget-völgy, Renget-völgy, Szeredvény-völgy, Szoros-völgy, Üsnök - $\underline{\text { Herb.: }}$ 2008.5.3., Vermes-völgy, Vizes-völgy; Istenmezeje: Felső-Kajra-völgy - $\underline{\text { Herb.: }}$ 2007.5.18., Hegyes-kukucsa, Remete-les (BÁ); Kissikátor: Renget-völgy (SJ). CEU: [7786.4], [7787.3], [7885.4], [7886.2], [7886.4], [7887.1], [7887.3], [7985.2], [7986.1].

542,1. Cardamine pratensis L. subsp. matthioli (Moretti) Nyman - Égerliget menti magassásosban és lápréten. Tv: Hangony: Hangonyi-Renget-völgy; Óm: Borsodnádasd: Hódospatak-völgye - $\underline{\text { Herb.: }}$ 2007.4.29. (BÁ). CEU: [7886.2], [7887.4].

553. Lunaria rediviva L. - Törmeléklejtő erdőben, kőtörmelékes üde bükkösökben, hárskőris sziklaerdőkben, ritkábban kőtörmelékes gyertyános tölgyesben. A régióban a Bükkön és a Mátrán kívül az Upponyi-hegységből az Upponyi-szorosból ismert előfordulása (VojTKó 1994, 1995). Uhg: Uppony: a Csernely-patak belterületi szakaszán égerligetben, Eszkálatető (BÁ), Lázbérci-víztároló, Vízköz (SJ). CEU: [7788.4].

558. Alyssum montanum L. - Molyhos tölgyes homokköves erdőkben és homokkősziklagyepekben, valamint nyíltabb gyepekben. Az Upponyi-hegységből elsőként Budai József gyűjti Uppony mellől közelebbi helymegjelölés nélkül (1910.6.6. - BP-75129). Uhg: Borsodbóta: Tó-padja; Sajómercse: Ágazat-völgy; Sáta: Kotyindó-tető (SJ); Uppony: Cibróka - Herb.: 2008.5.1. (BÁ), Csipeles-domb - a Zsinnyétől nyugatra eső 347,9 m-es domb (SI);

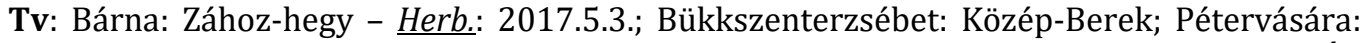
Lyukas-kő-hegy - $\underline{\text { Herb.: }}$ 2007.4.30.; Szentdomonkos: Henc-ortvány - Herb.: 2017.5.1. (BÁ). CEU: [7788.3], [7788.4], [7887.4], [7888.1], [7985.2], [7986.2], [7986.3], [7987.1].

574. Camelina microcarpa Andrz. ex DC. - Száraz és félszáraz gyepek felnyíló részein szórványos. Uhg: Borsodbóta: Sáros-út, Vatos; Uppony: Csipeles-domb; Óm: Borsodnádasd: Szalinca (SJ). CEU: [7788.3], [7788.4], [7887.4], [7888.1].

589. Thlaspi jankae A. Kern. - A Bükk és a Mátra előterében gyakori fajnak a vizsgált területen eddig csak egyetlen adata volt ismert az Upponyi-hegyhát területéről a királdi Vártetőről (SULYOK \& SCHMOTZER 1999). Ezen kívül Vojtkó András találja 1996-ban Uppony közelében [1]. Bh: Hevesaranyos: Körtélyes - meredek oldalgerinc felnyíló cseres-tölgyesének kis gyepfoltjában; Pm: Hevesaranyos: Víg István-tető - tölgyes szegélyében lévő löszös, száraz gyepben; Tarnalelesz: Lóhát-orom - erdőssztyep-erdő maradvány szegélyében (SJ). CEU: [7986.4], [7987.3]. 
607. Diplotaxis erucoides (L.) DC. - Aszfalt utak menti földsávban lévő nyíltabb gyepekben, vagy szinte teljesen szabad földfelszíneken ritka. A növényre az utóbbi években - feltehetően a gyepek záródása miatt - már nem sikerült rátalálni. A faj Magyarország területéről 1986-ban került elő Ózd és Bánréve határából kukorica-, lucerna-, lóhere-, és bab ültetvényekből, valamint szőlősből (CZIMBER et al. 1990). Ózdi növényektől származó magvakat további fenológiai vizsgálatok céljából a mosonmagyaróvári és a szegedi botanikus kertekben vetették el (GuLYÁs \& CZIMBER 1990). Óm: Ózd: Nagy-fák-alja - $\underline{\text { Herb.: }}$ 2007.3.31. - a Borbás-hegy aljában, a közút rézsűjében (BÁ). CEU: [7787.4].

608. Diplotaxis muralis (L.) DC. - Nyíltabb száraz gyepek és homokkő-sziklagyepek növénye. SUBA (1963) már említi a Tarnavidékről, Szentdomonkos határából. Uhg: Uppony:

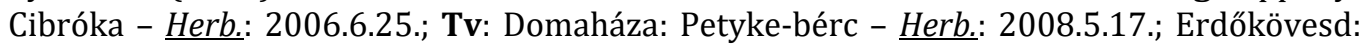

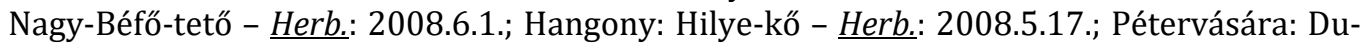
dar-hegy - Herb.: 2008.6.15.; Tarnalelesz: Henc-ortvány - Herb.: 2008.5.4.; Zabar: Kő-verő -

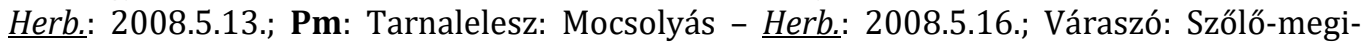
hegy - $\underline{\text { Herb.: }}$ : 2008.5.13., Varga-Bernát - Herb.: 2008.5.13.; Uh: Borsodbóta: Nagy-cihár Herb.: 2008.5.1. (BÁ). CEU: [7786.4], [7787.3], [7788.3], [7788.4], [7886.1], [7986.2], [7986.3], [7987.1].

628. Reseda phyteuma L. - Nyílt száraz gyepekben, homokkő-sziklagyepekben és földutak mentén. Mindenütt csak néhány töve. Tv: Borsodszentgyörgy: Kígyós-hegy; Ózd: Harmaci-

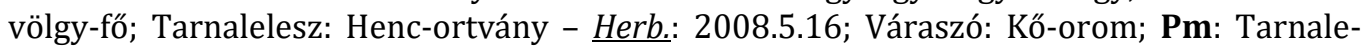
lesz: Dugzó-oldal; Uh: Arló: Benéte (BÁ). CEU: [7787.1], [7887.1], [7887.2], [7986.2], [7987.1].

634,2. Jovibarba globifera (L.) J. Parn. - Mészkősziklagyepekben. VojtKó (1995) Jovibarba hirta néven közölte a Kalica-tetőről és az Upponyi-szorosból. Uhg: Dédestapolcsány: Dezsőkő, Éles-kő, Somos-bérc - az Ata-völgytől délnyugatra lévő 343,9 m-es hegy; Nagyvisnyó: Somos-cserje. Uppony: Dedevár, Eszkála-tető, Fekete-kő-tető, Vízköz (SJ). CEU: [7788.4], [7888.2], [7888.4].

643. Sedum acre L. - Tv: Pétervására: Lyukas-kő-hegy - nyílt száraz gyepben a homokkősziklafal alatt (BÁ). CEU: [7986.3].

645. Saxifraga bulbifera L. - Bh: Bükkmogyorósd: Róka-lyuk - sztyepréten; Uhg: Borsodbóta: Epres-mál - enyhén mészkerülő száraz gyepben (SJ). CEU: [7788.3], [7988.1].

660,1. Ribes rubrum L. s. str. var. rubrum L. - Az Északi-középhegységben szórványos előfordulású var. rubrum-nak a legközelebbi előfordulása Szilvásvárad mellett található (SulyoK \& SCHMOTZER 1999). Új a Tarnavidékre. Tv: Arló: Gyepes-völgy - égerligetekben (SJ). CEU: [7887.1].

663. Spiraea media Schmidt - Uhg: Uppony: Eszkála-tető - sziklai cserjésekben állományalkotó; Tv: Cered: Nagy-oldal - a homokkő-sziklafal árnyasabb, déli részén szép cserjést alkot. A faj a szomszédos kvadrátból (7885.3) - például a közeli Szilvás-kőről - régóta ismert (CSIKY 2004). A nemrégiben közölt adathoz (MolNÁR et al. 2019) tartozó cönológiai felvételt itt adjuk közre. A faj a Tarnavidékről ezidáig nem volt ismert (BARTHA et al. 1999). Cered: Nagy-oldal. 2016. június 2., szeptember 20. és 2017. május 3 . kvadrátméret: $10 \times 5$ méter, tengerszint feletti magasság: $397 \mathrm{~m}$, cserjeszint borítása: 50\%, gyepszint borítása: 40\%, szabad sziklafelszín: 10\%, alapkőzet: miocén homokkő (Pétervásárai Homokkő Formáció), lejtőszög: 40-50\%, kitettség: K-ÉK, GPS koordináták: 48,12123 N 19,94005 E; 48,12115 N, $19,94005^{\circ} \mathrm{E} ; 48,12125^{\circ} \mathrm{N}, 19,9401^{\circ} \mathrm{E} ; 48,12115^{\circ} \mathrm{N}, 19,94013^{\circ} \mathrm{E} ; \mathrm{KEF}: 7885.4$

B szint: 3: Spiraea media 1: Pyrus pyraster, Rosa canina +-1: Crataegus monogyna C szint: 1: Asplenium trichomanes, Carduus collinus, Euphorbia cyparissias, Melica ciliata, Sedum acre, Verbascum lychnitis, Vicia villosa subsp. villosa +-1: Arenaria serpyllifolia, Centaurea stoebe, Elymus hispidus, Galium aparine s.l., Geranium sanguineum, Hylotelephium telephium subsp. maximum, Iris variegata, Lactuca viminea, Poa angustifolia, Taraxacum laevigatum, 
Teucrium chamaedrys, Thymus praecox subsp. praecox +: Asperula cynanchica, Geranium columbinum, Hypericum perforatum, Medicago minima, Myosotis arvensis, Stachys recta, Valerianella locusta, Vicia hirsuta Acc. (néhány egyed): Achillea pannonica, Acinos arvensis, Anthriscus cerefolium subsp. trichospermus, Arrhenatherum elatius, Berteroa incana, Bromus sterilis, Chamaecytisus triflorus, Chelidonium majus, Fallopia convolvulus, Festuca rupicola s.l., Lamium purpureum, Lapsana communis, Mycelis muralis, Prunus spinosa, Quercus pubescens, Securigera varia, Seseli osseum, Silene alba, Viola arvensis;

Tarnalelesz: Szarvas-kő-orom - egyetlen bokra egy homokkőkibúváson sziklás melegkedvelő tölgyesben (BÁ). CEU: [7788.4], [7885.4], [7886.4].

685. Rosa gallica L. - Száraz és félszáraz gyepekben, száraz tölgyesekben, erdőszegélyekben. Bh: Bátor: Megyaszó-fő; Bekölce: Láz; Bükkmogyorósd: Egres-völgy; Hevesaranyos: Dakó-hegye, Ecser-hegy, Gyilkos-tető, Körtélyes, Nagy-lápa-tető; Uhg: Bánhorváti: Málioldal; Borsodbóta: Epres-mál, Menyhárt, Ragicca, Tó-padja, Vatos, Veres-domb, Veres-tető; Dédestapolcsány: Balta-tető, Bárci-tető - a Bárci-oldaltól keletre lévő 311,9 és 301,4 m-es vonulat, Halabuka-tető, Hosszú-berek-tető - a Halabuka-tető északnyugati gerince a 273,0 m-es gerinccel, Kerek-domb, Köszörűs és varjas, Kukorica-föld, Nagy-hegy, Nagy-hegyiszőlő - a Nagy-hegy keleti gerincének déli oldalában lévő felhagyott szőlők és gyümölcsösök, Varjas-szőlő; Nekézseny: Nagy-mál-tető, Szégyen-tető, Szőlő-mál-tető, Zsellér-földek; Sajómercse: Mercse-ágazat; Sáta: Hosszak és Kéri-tó, Pap János, Pipis-hegy (SJ); Uppony: Cibróka (BÁ), Három-kő, Kalica-tető; Tv: Arló: Futyóköz-orma, Kis-Poporó, Közép-Poporó, Nádú-bérc, Nagy-Poporó, Pados-bérc - a Pados-tető keleti gerince, Remete-bérc; Borsodnádasd: Hasznos, Karácsonylova, Kerek-berek-fő, Lapuhas-eleje; Domaháza: Nyárjasság (SJ), Szekeres-Bükk - $\underline{\text { Herb.: }}$ 2008.5.30., Telek-felé, Zálogos (BÁ); Istenmezeje: Tamás telkefő; Váraszó: Szénégető-hegyese; Óm: Borsodnádasd: Szalinca; Pm: Fedémes: Kútos-tető, Víg István-tető; Hevesaranyos: Bodony-árnyék; Tarnalelesz: Dancsok, Dancsok-far, Madarászó, Nagy-hegyesse; Uh: Arló: Izra-völgy, Ladány-tető, Pocsi-bérc, Szohony; Borsodbóta: Őr-hegy (SJ); Borsodnádasd: Balatoni-tető, Budaberke, Mocsolyás-tető - $\underline{\text { Herb. }}$ : 2009.5.23. (BÁ); Csernely: Ali-út-tető, Ali-völgy, Alsó-Nyékes, Borjúmáj, Borsostartó-tető, Eperjes, Lukács Gergelyesse, Palánt-tető, Pete-fia; Csokvaomány: Alsó-pást, Babos, Liba-tető, Nyékes-tető, Palánt-tető, Pap-hegyese, Páter-oldal, Vasút-tető - a vasútállomás fölötti domb; Járdánháza: Szalinca; Sajómercse: Adár-bérc - az Adár-völgytől délnyugatra eső gerinc, Gógány, Kerek-rét, Szarvaskút, Szörnyű-völgy; Sajóvelezd: Lapos-kő, Lapos-kő alja, Vár-erdő (SJ). CEU: [7788.2], [7788.3], [7788.4], [7886.1], [7886.2], [7886.3], [7886.4], [7887.1], [7887.2], [7887.3], [7887.4], [7888.1], [7888.2], [7888.3], [7986.4], [7987.1], [7987.2], [7987.3], [8087.1].

690. Rosa rubiginosa L. - Száraz gyepekben, cserjésekben. Uhg: Nagybarca: Csiga-tető; Pm: Bükkszék: Csigdászó; Tarnalelesz: Nagy-hegyesse (SJ). CEU: [7789.3], [7986.4], [7987.3].

692. Rosa gizellae Borbás - Homokkőkibúvások alatti nyílt száraz gyepekben és sztyepréteken ritka. Homokkő alapkőzetről Boros Ádám gyűjti adatát a bárnai Nagykő alól (1936.6.17. - BP-435980). A növény Karancs és Medves környéki - részben homokkő alapkőzetről származó előfordulásait - CsıKY (2004) foglalja össze, feldolgozva pl. Hulják János (1933), Boros Ádám (1936) és saját adatait is. A növénynek még a Bükkből ismert adata Kisgyőr mellől (BuDAI 1913, BUdAI ap. VojTKó 2001, KERÉNYI 2010). SULYOK (2011) Bánhorváti: Rózsás dűlőből publikált Rosa hungarica adata is erre a fajra vonatkozik. A növény a kutatott terület minden tájegységére új. Uhg: Borsodbóta: Tó-padja; Dédestapolcsány: Nagy-hegy; Nekézseny: Nagy-mál-tető; Sáta: Kotyindó-tető; Uppony: Eszkála-tető, Feketekő-tető; Tv: Szentdomonkos: Kő-hegy; Váraszó: Kő-orom; Pm: Bükkszék: Leleszi-szállás; Tarnalelesz: Meszes-dűlő, Tormás-hegy; Uh: Sajómercse: Szarvaskút (SJ). CEU: [7788.3], [7788.4], [7888.1], [7888.2], [7986.2], [7986.4], [7987.1]. 
709. Agrimonia procera Wallr. - Zavart erdőszegélyekben. Elsőként KIRÁLY \& KIRÁLY (2018) publikálja a Tarnavidékről, a borsodszentgyörgyi Palina-völgyből. Új az Upponyihegyhátra. Tv: Borsodnádasd: Kő-völgy, Német-út; Uh: Arló: Izra-völgy (SJ). CEU: [7887.2], [7887.3].

716. Waldsteinia geoides Willd. - Hárs-kőris sziklaerdőben, melegkedvelő tölgyesben, kőtörmelékes bükkösben, a Tarnavidéken gyertyános-tölgyesben. Az Upponyi-hegységben az Upponyi-szorosban Budai József (1912.5.5. - BP-88273), Boros Ádám (1934.7.7. - BP435497), a Háromkő-bércen Szujkóné Lacza Júlia és Kováts Dezső (1982.10.5. - BP618308), valamint a Csernely-patak völgyében Beránek Ábel (2005.5.21. - BP-692173) gyűjtötte. A Bükkben és a Mátrában gyakori növénynek a Tarnavidékről eddig nem volt adata. Uhg: Bánhorváti: Éles-kő; Dédestapolcsány: Éles-kő; Nekézseny: Zsellér-földek; Uppony: Bender-oldal, Eszkála-tető, Lázbérci-víztároló (SJ), Vízköz (BÁ), Zsellér-földek; Tv: Arló: Nádú-árnyék; Borsodszentgyörgy: Palina-völgy (SJ). CEU: [7788.4], [7887.1], [7888.2].

720. Potentilla alba L. - Carex montanas enyhén mészkerülő félszáraz gyepekben. Bh: Hevesaranyos: Gyilkos-tető; Uhg: Bánhorváti: Lapác (SJ). CEU: [7788.4], [7987.3].

721. Potentilla micrantha Ramond ex DC. - Cseres- és gyertyános-tölgyesekben. SuBA (1969) már említi a fajt a tájegységből Dolmony- és Palinapuszta mellől. Tv: Pétervására: Vaskapu - Herb.: 2007.4.30.; Tarnalelesz: Agyagos-hegyes, Kőkút, Kovasszó-fő, Macskalyukhegy, Peskő-tető, Szállás-verő-hegy, Szarvas-kő, Szederjes-verő - Herb.: 2009.4.12., Szihalom-far (BÁ). CEU: [7886.4], [7986.2], [7986.3].

748. Alchemilla micans Buser - Üde, völgyközeli, erdőszéli gyepekben ritka. A növény első adata a Tarnavidékről Vojtkó Andrástól (VoJTKó 2008) származik. Új az Upponyi-hegyhátra. Óm: Borsodnádasd: A lemezgyári völgyben a belterület szegélyében, a régi sípálya végénél; Uh: Ózd: Kígyós-völgy - gázvezeték pásztájában (BÁ). CEU: [7887.2], [7887.4].

761. Sorbus domestica L. - Cseres- és melegkedvelő tölgyesekben sokszor csak fiatal egyedek, felhagyott gyümölcsösökben idős termő fák is. Bh: Hevesaranyos: Dóna-verő; Uhg: Bánhorváti: Nagy-oldal; Dédestapolcsány: Bárci-tető, Éles-kő-tető, Halabuka-tető, Hosszúberek-tető, Nagy-hegyi-szőlő, Nagy-hegy-orom, Sár-bérc, Varjas-szőlő; Nekézseny: Fehérkő, Upponyi Közép-bérc (SJ); Uppony: Cibróka (BÁ); Tv: Arló: Kis-Poporó, Közép-Poporó, Nagy-Poporó (SJ); Tarnalelesz: Vermes-hát (BÁ); Uh: Sajóvelezd: Lapos-kő (SJ). CEU: [7788.2], [7788.4], [7887.3], [7888.2], [8087.1].

768. Sorbus danubialis (Jáv.) Kárpáti - Sziklaerdőkben, sziklagyepekben, sziklai cserjésekben. SUlYOK \& SCHMOTZER (1999) Szilvásvárad: dobogó-hegyi adata valójában Sorbus buekkensis-nek bizonyult a 2017-ben végzett felmérés során (SL-SJ). Uhg: Borsodbóta: Tópadja; Uppony: Dedevár, Eszkála-tető (SJ), Három-kő - Zólyomi Bálint 1927.8.4-én gyűjtött Sorbus aria ssp. soói adatának megerősítése, amely valójában $S$. danubialis (SOMLYAY \& SENNIKOV 2016) (SL-SJ), Kalica-tető, Upponyi-szoros - Boros Ádám adatának megerősítése, aki 1934-ben „Sorbus aria ssp. Jávorkae Soó” (BoRos 1934, KÁRPÁTI 1960), majd 1960-ban már „Sorbus Soói (Máthé) Kárp.” néven jelzi (Boros 1960), Vízköz (SJ). CEU: [7788.3], [7788.4], [7888.3].

772. Sorbus torminalis (L.) Crantz - Cseres- és gyertyános-tölgyesek elegyfája. Uhg: Nekézseny: Avas-bérc, Upponyi-tető; Tv: Istenmezeje: Alsó-Hagymás-bérc; Uh: Borsodnádasd: Budaberke, Csiterkötő, Mesgye-hegy; Ózd: Bótai-tető (BÁ). CEU: [7788.3], [7887.4], [7888.2], [7986.1].

775. Sorbus zolyomii (Soó) Kárpáti - A növény eddig csak a Bükkből és a Mátrából volt ismert (KÁRPÁTı 1960). Uhg: Dédestapolcsány: Nagy-hegy-orom - a hegy köves gerincén, erdőszegélyben egy termőképes fa és három fiatal fácska (SJ). CEU: [7888.2].

810. Cotoneaster niger (Thunb.) Fr. - A sziklagyepekben, sziklai cserjésekben előforduló cserjefaj az Upponyi-hegységből régóta ismert, részben C. matrensis néven (ZólYOMI 1934, 
Soó 1943, VojTKó 1994, 1995, BARTHA et al. 1999), de előfordul még Sajóvelezd mellett is SULYOK \& SCHMOTZER 1999). Uhg: Uppony: Eszkála-tető (SJ), Három-kő (SJ-SL) - Az élőhelyen együtt található meg a sokkal ritkább $C$. integerrimus-val, amelyet még Budai József talált 1912-ben (BUDAI 1914). CEU: [7788.4].

817. Padus avium Mill. - Uhg: Dédestapolcsány: Éger-alja - patak menti égerligetben szórványos (SJ). CEU: [7888.2].

821. Cerasus fruticosa (Pall.) Woronow - Cserjésekben, erdőssztyep-erdő maradványokban, erdőszegélyekben, félszáraz gyepekben szórványos. Bh: Bátor: Boza; Bekölce: Perekonyabérc; Uhg: Bánhorváti: Nagy-hegy; Borsodbóta: Vatos; Dédestapolcsány: Balta-tető, Kerekdomb, Nagy-hegy, Nagy-hegyi-szőlő; Nekézseny: Nagy-mál-tető, Szégyen-tető; Sáta: Kotyindó-tető; Uppony: Három-kő; Óm: Borsodnádasd: Sülye-völgyi-bérc, Szalinca; Pm: Tarnalelesz: Dancsok-far; Uh: Csernely: Borjúmáj, Nyékes-tető; Sajómercse: Szörnyű-völgy; Sajóvelezd: Lapos-kő (SJ). CEU: [7788.2], [7788.3], [7788.4], [7887.3], [7887.4], [7888.1], [7888.2], [7986.4], [7987.2], [7987.4].

837. Corothamnus procumbens (Waldst. et Kit.) C. Presl - Sztyeprétek, ritkábban homokkősziklagyepek növénye. Bh: Bekölce: Perekonya-bérc (SJ); Tv: Bükkszenterzsébet: Közép-

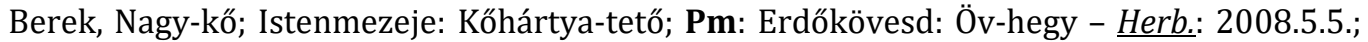
Pétervására: Repenye - $\underline{\text { Herb.: }}$ 2017.4.14. (BÁ); Tarnalelesz: Lóhát-orom, Tormás-hegy (SI); Váraszó: Barca Tamás hegy - Herb.: 2017.5.4., File lova, Heregvár - Herb.: 2017.5.4., Ó-hegy, Öv-hegy (BÁ). CEU: [7986.1], [7986.2], [7986.4], [7987.1], [7987.2].

839. Chamaecytisus virescens (Kováts ex Neilr.) Dostál - Cserjésekben, tölgyesek szélén, sztyepréteken szórványos. A korábban - szintén Domaháza községhatárából - Chamaecytisus austriacus-ként közölt néhány adat (BERÁNEK 2008) is erre a fajra vonatkozik. A még hiányos elterjedési adatokkal rendelkező fajnak Pifkó Dániel (PIFKó 2004) szerint biztosan a Bükkből és a Mátrából van a legközelebbi előfordulási adata. A Chamaecytisus austriacus északi középhegységi előfordulási adatainak további felülvizsgálata vélhetően pontosítani fogja a faj elterjedési területét. A Tarnavidékre új. Tv: Domaháza: Aszaló-Bikk Herb.: 2009.6.13., Bükk-tető - Herb.: 2009.6.13., Csurgó-bérc, Kerek-Bükk - Herb.: 2009.7.4., Kis-Szegeggye-tető, Malomló - Herb.: 2009.7.4. (BÁ), Mihály-homloka (SJ), Mihály-tető - Herb.: 2009.8.1., Örvényes, Répás-tető - Herb.: 2009.7.4., Répás-verő, SzekeresBükk, Szörnyü, Telek-felé, Tő-völgy (BÁ). CEU: [7886.1], [7886.2].

841. Chamaecytisus albus (Hacq.) Rothm. - Félszáraz és száraz gyepekben, melegkedvelő tölgyesekben, erdőszegélyekben. Eléggé elterjedt faj, amely helyenként nagy egyedszámban fordul elő. A gyepek rendszeres égetését is jól tưri. Az Upponyi-hegységből Zólyomi Bálint gyűjti az upponyi Három-kőről (1927.8.4. - BP-641675), Hegedűs Ábel pedig Sajóvelezd mellett közelebbi helymegjelölés nélkül (1983.5.15. - BP-420150). Az Upponyihegyhátból elsőként Boros Ádám gyűjti a sajómercsei Magas-hegyen (1960.7.2. - BP449054). Bh: Bekölce: Perekonya-bérc; Bükkmogyorósd: Salamon-vár, Szőlő-hegy; Csernely: Bazsik; Hevesaranyos: Dakó-hegye, Ecser-hegy, Gyilkos-tető, Kis-bügör, Kopasz-orom, Körtélyes, Köszörűs, Nagy-lápa-tető, Ürge-lápa, Veres-hegy; Uhg: Bánhorváti: Bárci-oldal, Bárci-tető, Éles-kő-tető, Hosszú-berek; Borsodbóta: Gyűre, Menyhárt, Tó-padja, Vatos, Veres-domb; Dédestapolcsány: Bárci-tető, Éles-kő, Éles-kő-tető, Halabuka-tető, Hosszú-berektető (SJ), Kerek-domb - $\underline{\text { Herb.: }}$ 2008.7.15. (PD-SJ), Köszörűs és varjas, Kukorica-föld, Nagyhegy, Nagy-hegy-orom, Varjas-szőlő (SJ); Nekézseny: Nagy-mál-tető; Sajómercse: Ágazatvölgy, Finta-tető - a Finta-völgytől délre eső hegygerinc; Sáta: Hosszak és Kéri-tó (SJ), Kotyindó-tető - Herb.: 2008.7.15. (PD-SJ), Pipis-hegy; Uppony: Csipeles-domb, Három-kő Herb.: 1927.8.4. (BP-641675), Zólyomi Bálint adatának megerősítése; Tv: Arló: KözépPoporó (SJ); Szentdomonkos: Kőalja-kertmegi-dűlő; Tarnalelesz: Henc-ortvány - Herb.: 2008.5.16. (BÁ); Pm: Fedémes: Árpaszó-hegy, Kútos-tető, Víg István-tető; Hevesaranyos: Barci-far, Bodony-árnyék, Fedémesi-patak völgye, Kaptás, Sirokaszó, Sirokaszó-fő; Szent- 
domonkos: Pap-hegy, Sár-fenék, Tormás-hegy, Virág-vár; Tarnalelesz: Csigdászó, Lóhátorom, Meszes, Nagy-hegyesse, Tormás-hegy (SJ); Uh: Borsodbóta: Csépány-tető - a Bükk-fő északkeleti gerince; Borsodnádasd: Budaberke - $\underline{\text { Herb.: }}$ 2008.7.12., Mesgye-hegy - $\underline{\text { Herb. }}$ : 2008.7.12. (BÁ); Csernely: Borjúmáj, Ecetes-Tök, Eperjes (SJ), Gárdony-tető - Herb.: 2008.7.15. (PD-SJ), Nagy-Horsó-völgy, Nemecke - a Nyékes-tetőtől északnyugatra lévő 394,9 m-es hegy, Palánt-tető, Pete-fia; Csokvaomány: Babos (SJ), Kis-Omány-oldal, Kőbánya-hegyese (BÁ), Liba-tető, Palánt-tető, Pap-hegyese - Herb.: 2008.7.15. (PD-SJ), Páter-

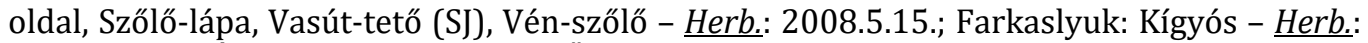

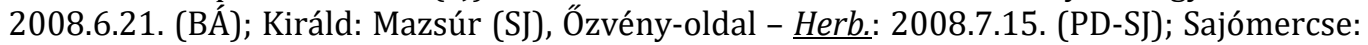
Gógány, Kerek-rét, Kisbikk, Körtvélyes, Nagy-hegy - a Nagy-völgyi-tanyától keletre eső 338,1 m-es hegy és 327,4 m-es gerince, Nyúzó-völgy (SJ); Sajónémeti: Rátos - a Vár-hegytől északkeletre eső hegy - Herb.: 2008.6.16. (BÁ); Sáta: Babos (SJ), Kós-ortvány - Herb.: 2009.8.18., Liba-hegy (BÁ). CEU: [7787.4], [7788.1], [7788.3], [7788.4], [7887.2], [7887.3], [7887.4], [7888.1], [7888.2], [7888.3], [7889.1], [7986.4], [7987.1], [7987.2], [7987.3], [8087.1], [8087.2].

845. Chamaecytisus ciliatus (Wahlenb.) Rothm. - Északi kitettségű cserjés üdébb gyepekben, erdei utak mentén cseres-tölgyesekben, sziklás melegkedvelő erdőben. Uhg: Dédestapolcsány: Dezső-kő (SJ); Tv: Hangony: Magas-hegy - Herb.: 2008.5.31., Ragyvás-fő - Herb.: 2008.5.18.; Ózd: Nagy-oldal; Uh: Csokvaomány: Árendás-oldal - a Határ-bérctől északra eső gerinc, a topográfiai térképen Árendás-erdő néven (BÁ). CEU: [7786.4], [7787.1], [7787.3], [7888.1], [7888.2].

846. Chamaecytisus triflorus (Lam.) Skalická - Mészkerülő erdőkben, sziklás melegkedvelő tölgyesekben, erdőszegélyekben, útrézsűkben, ritkábban gyepekben, cserjésekben. Uhg: Borsodbóta: Tó-padja, Vatos; Tv: Arló: Kis-Poporó, Közép-Poporó, Nádú-bérc, Nagy-Poporó, Pados-bérc (SJ); Borsodnádasd: Dögkert-fó - Herb.: 2005.4.23. (BÁ); Domaháza: Hajagos (SI); Hangony: Hilye-kő - Herb.: 2007.4.27.; Istenmezeje: Kőhártya-tető - Herb.: 2008.6.1. (BÁ); Kissikátor: Tiszta-tető (SJ); Ózd: Harmaci-völgy-fö, Nagy-oldal; Pétervására: Lyukas-kő-hegy, Vaskapu; Tarnalelesz: Debornya-bérc - $\underline{\text { Herb.: }}$ 2005.4.23. (BÁ); Váraszó: Szénégető-hegyese; Óm: Borsodnádasd: Szalinca; Uh: Arló: Fazekas-árnyék - a Fazekas-oldaltól északnyugatra eső gerinc, Konnya-völgy, Ladány-tető, Szohony; Csernely: Eperjes, Kis-Csej-völgy, Lukács Gergelyesse, Nagy-Horsó-völgy, Nyékes-tető, Pete-fia, Úszó-fő (SJ); Járdánháza: Mocsolyás Herb.: 2008.6.2. (BÁ), Szalinca; Sajómercse: Adár-bérc, Gógány, Kerek-rét, Szarvaskút, Szörnyü-völgy, Tarkai-parlag (SJ). CEU: [7787.1], [7787.3], [7788.3], [7886.1], [7886.2], [7886.4], [7887.1], [7887.2], [7887.3], [7887.4], [7888.1], [7986.1], [7986.3].

848. Genista germanica L. - Mészkerülő gyepekben, legelőkön, erdőszegélyekben. Első tarnavidéki adatát MolnÁr et al. (2017) közli Domaháza határából. Bh: Bükkmogyorósd: Csurgó - a Csurgó-forrástól nyugatra lévő dombvonulat (SJ); Uhg: Bánhorváti: Somlyó Herb.: 2007.5.16. (BÁ); Borsodbóta: Vatos, Veres-domb (SJ); Tv: Domaháza: Aszaló-Bikk, Asztag-völgy-bérc, Asztag-völgy-hegy, Csurgó-bérc, Felső-völgy, Hintós-árnyéka, JósOrtvány-tető, Kerek-Bükk, Kis-kút és Utas-völgy, Mihály-homloka, Mihály-tető - $\underline{\text { Herb.: }}$ 2008.5.31., Nagy-Ravasz-lyuk - Herb.: 2008.5.18., Nehák, Petyke-bérc - Herb.: 2008.5.17., Répás-tető, Szekeres-Bükk, Szilvás-árnyéka, Szörnyű, Telek-felé, Utas-árnyék, Utas-fő, Zálogos; Hangony: Petyke-bérc; Uh: Csokvaomány: Farkas-tető, Nyékes-tető (BÁ); Sajómercse: Adár-bérc, Gógány, Kerek-rét, Szörnyü-völgy (SJ). CEU: [7786.4], [7788.3], [7789.3], [7886.1], [7886.2], [7888.1], [7888.3].

849. Genista pilosa L. - Mészkerülő tölgyesek jellemző faja, amely szórványosan szilikátszik-

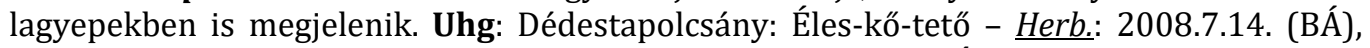
Halabuka-tető, Lipóc (SJ), Malom-hegyese - Herb.: 2008.6.21. (BÁ), Nagy-árnyék, Nagy-erdő (SJ), Nagy-hegy-orom, Rádincs-völgy (BÁ), Vak-völgy (SJ); Nekézseny: Avas-bérc, Bányaoldal, Upponyi Közép-bérc (BÁ); Uppony: Dedevár, Vízköz (SJ). CEU: [7788.4], [7888.2]. 
857. Robinia hispida L. - Pincék közelében kivadulva. Uhg: Dédestapolcsány: Kukorica-föld, Veszett-szög (SJ). CEU: [7888.2].

861. Colutea arborescens L. - Melegkedvelő és cseres-tölgyesekben, délies kitettségű száraz cserjésekben és gyepekben, szórványosan félszáraz gyepekben, erdőszegélyekben. Bh: Borsodnádasd: Láz (BÁ); Hevesaranyos: Ecser-hegy, Köszörűs; Uhg: Bánhorváti: Máli-oldal (SJ); Dédestapolcsány: Halabuka-tető (BÁ), Nagy-hegy, Nagy-hegy-alja - a Kerek-domb és a Nagy-hegy keleti régi szőlői közötti hegylábi terület (SJ), Nagy-hegyi-szőlő (BÁ), Nagyhegy-orom (SJ), Rigós-lápa (BÁ), Sár-oldal, Varjas-szőlő; Nekézseny: Zsellér-földek; Sáta: Hosszak és Kéri-tó; Uppony: Fekete-kő-tető, Kalica-tető (SJ), Upponyi-szoros (BÁ), Vízköz; Tv: Arló: Nádú-bérc (SJ); Borsodnádasd: Lapuhas; Bükkszenterzsébet: Közép-Berek; Pétervására: Borostyános-bérc, Dudar-hegy, Lyukas-kő-hegy, Szalonnás-fő - a Nagy-lyukas-kőtől északkeletre eső hegygerinc; Tarnalelesz: Henc-ortvány (BÁ); Váraszó: Fenekes, Kő-orom; Pm: Hevesaranyos: Víg István-tető (SJ); Pétervására: Sírmány (BÁ); Tarnalelesz: Dancsokfar (SJ); Váraszó: Öv-hegy; Uh: Borsodbóta: Csépány-tető (BÁ); Csernely: Lukács Gergelyesse (SJ); Csokvaomány: Andornak, Kis-Omány-oldal, Vén-szőlő (BÁ); Sajómercse: Szarvaskút (SJ); Sajónémeti: Rátos-tető, Vár-hegy; Sáta: Bükkfő (BÁ). CEU: [7788.1], [7788.3], [7788.4], [7886.3], [7886.4], [7887.2], [7887.3], [7888.1], [7888.2], [7986.2], [7986.3], [7986.4], [7987.1], [7987.2], [7987.3], [8087.2].

866. Astragalus exscapus L. - Tv: Ózd: Kanizsa-tető - Herb.: 2012.5.21. - akácelegyes melegkedvelő tölgyes nyíltabb részein több száz tő; Óm: Ózd: Borbás-hegy - $\underline{H e r b .: ~ 2012.5 .6 . ~-~}$ nyílt száraz gyepben több ezer töves állománya; Kő-tető - akácosodó száraz gyepben néhány száz töve. Bartha Csaba már jelzi a fajt 2004-ben a flóratérképezési program során a 7787.4-es kvadrátból, mely valószínúleg a borbás-hegyi adatra vonatkozik [1] (BÁ). CEU: [7787.4], [7788.1].

870. Astragalus cicer L. - Tv: Domaháza: Tó-völgye-patak - aszfaltút menti gyepben ritka (BÁ). CEU: [7886.1].

872. Astragalus austriacus Jacq. - Félszáraz gyepekben, sztyepréteken ritka. Óm: Ózd: Szilas-alja-hegyese, Szilas-tető; Pm: Bükkszék: Csigdászó; Hevesaranyos: Kaptás, Kis-Ecser; Tarnalelesz: Bolya-puszta, Lóhát-orom, Madarászó, Meszes (SJ). CEU: [7787.3], [7986.4], [7987.3].

879. Amorpha fruticosa L. - Utak rézsűjében, a talajerózió megakadályozása érdekében került betelepítésre. Uhg: Bánhorváti: Bárci-tető - Herb.: 2008.8.10. (BÁ); Uh: Balaton: Mesgye-hegy (SJ). CEU: [7788.4], [7887.4].

891. Vicia pisiformis L. - Száraz tölgyesekben, erdőszegélyekben ritka. Uhg: Bánhorváti: Éles-kő-tető; Dédestapolcsány: Balta-tető, Éles-kő, Éles-kő-tető; Uppony: Bender-bérc, Bender-oldal; Pm: Hevesaranyos: Buja-hegy; Uh: Sajóvelezd: Lapos-kő (SJ). CEU: [7788.2], [7788.4], [7888.2], [7986.4].

892. Vicia dumetorum L. - Szurdokerdőben. Tv: Hangony: Szoros-völgy - Herb.: 2011.8.13. (BÁ). CEU: [7787.3].

901. Vicia pannonica Crantz - Felhagyott szőlők és gyümölcsösök száraz gyepjeiben. Uhg: Dédestapolcsány: Kerek-domb, Nagy-hegy-alja, Nagy-hegyi-szőlő (SJ). CEU: [7888.2].

901,2. Vicia pannonica Crantz subsp. striata (M. Bieb.) Nyman - Uhg: Sáta: Hosszak és Kéri-tó - másodlagos zavart száraz gyepben 4 egyed (SJ). CEU: [7888.1].

911. Lathyrus nissolia L. - Üdébb, franciaperjés és mészkerülő gyepekben szórványos, de néhol vetések és erdőgazdasági utak mentén is előfordul. Bh: Balaton: Nagy-völgy - $\underline{H e r b}$.: 2008.6.14.; Tv: Domaháza: Kovács-ortvány, Nagy-völgy, Nehák, Pácon-oldal - Herb.: 2008.5.30. (BÁ); Járdánháza: Cselény-völgy (SJ); Tarnalelesz: Kovasszó; Váraszó: Forró-fő (BÁ); Pm: Tarnalelesz: Csigdászó (SJ); Uh: Arló: Vár-hegy - Herb.: 2008.6.2.; Balaton: Varjas; Csokvaomány: Szósz-alja; Sáta: Csépány-berek (BÁ). CEU: [7788.3], [7886.1], [7886.2], [7886.4], [7887.1], [7887.2], [7887.4], [7888.1], [7986.4]. 
926. Lathyrus lacteus (M. Bieb.) Wissjul. - Bh: Egercsehi: Magas-hegy - egykori legelőerdő cserjésedő szegélyében 3 egyed (SJ). CEU: [7987.2].

933. Ononis pusilla L. - Szálkaperjés gyepek nyílt vagy erodált részein. Bh: Csernely: Bazsik (SJ); Tv: Borsodnádasd: Karácsony-hegy (BÁ), Óm: Borsodnádasd: Szalinca (SJ); Uh: Arló: Benéte - Herb.: 2008.6.2. (BÁ), Konnya, Ladány-tető, Pocsi-bérc, Szohony (SJ); Borsodbóta: Csépány-tető; Borsodnádasd: Balatoni-tető - $\underline{\text { Herb.: }}$ 2008.8.10. (BÁ); Csernely: Nemecke (SJ); Csokvaomány: Kis-Omány-oldal, Kőbánya-hegyese; Járdánháza: Pap-hegy (BÁ), Szalinca (SJ); Sáta: Liba-hegy (BÁ). CEU: [7788.3], [7887.2], [7887.3], [7887.4], [7888.1].

950. Medicago prostrata Jacq. - Uhg: Uppony: Eszkála-tető - déli kitettségú sziklafüves lejtőn (SJ). CEU: [7788.4].

972. Trifolium rubens L. - Szálkaperjés gyepekben és sztyepréteken, erdőszegélyekben, ritkábban melegkedvelő vagy felnyíló száraz tölgyesekben. Bh: Bekölce: Cseres-bérc (BÁ); Hevesaranyos: Gyilkos-tető; Uhg: Borsodbóta: Tó-padja, Vatos; Dédestapolcsány: Bárcitető, Kerek-domb, Köszörűs és varjas; Sáta: Hosszak és Kéri-tó; Tv: Arló: Nádú-bérc (SI); Domaháza: Aszaló-Bikk (BÁ); Pm: Fedémes: Kútos-tető; Uh: Arló: Ladány-tető, Szohony; Csernely: Alsó-Nyékes, Ecetes-Tök; Csokvaomány: Vasút-tető (SI); Farkaslyuk: Kígyós; Járdánháza: Pap-hegy (BÁ); Sajómercse: Adár-bérc, Gógány, Kerek-rét (SJ); Sajónémeti: Aszótető, Rátos; Sáta: Keserhet-völgy, Kós-ortvány, Liba-hegy (BÁ). CEU: [7788.1], [7788.3], [7886.2], [7887.2], [7887.3], [7887.4], [7888.1], [7888.2], [7987.2], [7987.3].

975. Trifolium ochroleucon Huds. - Cserjés gyepekben szórványos. Uhg: Sáta: Szőlő-gyakra (SJ); Tv: Domaháza: Aszaló-Bikk - Herb.: 2009.6.13., Istenmezeje: Víz-lápa-fó - Herb.: 2017.6.25. (BÁ). CEU: [7886.2], [7886.3], [7888.1].

991. Tetragonolobus maritimus (L.) Roth subsp. siliquosus (L.) Murb. - Az Északiközéphegységben a fajnak csak elszórt adatai vannak, elsősorban az Alföld felé néző hegylábperemeken. A legközelebbi előfordulása a Bükkből ismert Eger, Nagytálya (SCHMOTZER 2015) és Kács mellőll (VojTKó 2001), új a Tarnavidékre és az Upponyi-hegyhátra. Tv: Pétervására: Dudar-hegy - Herb.: 2008.6.15. kisebb árkok tagolta borókás gyepben (BÁ); Pm: Tarnalelesz: Meszes-dűlő, dombalji, többletvízhatásnak kitett szálkaperjés gyepben (SJ); Uh: Csokvaomány: Farkas-tető - Herb.: 2009.5.11. - egykori meddóhányó területén, átmozgatott talajon lévő gyepben (BÁ). CEU: [7888.1], [7986.3], [7986.4].

994,1. Anthyllis vulneraria L. subsp. polyphylla (Kit.) Nyman. - Szálkaperjés és száraz, felnyíló gyepekben, sziklagyepekben. Uhg: Borsodbóta: Halatvén-tető - a Halatvén-kúttól északnyugatra lévő hegy, Sáros-út; Dédestapolcsány: Kerek-domb, Nagy-hegy-alja, Nagyhegy-orom; Nekézseny: Nagy-mál-tető; Sáta: Hosszak és Kéri-tó, Kotyindó-tető; Tv: Járdánháza: Köves-hegy; Óm: Borsodnádasd: Szalinca; Uh: Csernely: Ecetes-Tök, Eperjes, Nemecke, Nyékes-tető, Úszó-fő; Sajómercse: Gógány (SJ). CEU: [7788.3], [7887.2], [7887.3], [7887.4], [7888.1], [7888.2], [7888.3].

999. Hippocrepis comosa L. - Nyíltabb száraz és félszáraz gyepek, sztyeprétek, valamint homokkő-sziklagyepek gyakori növénye. Bh: Bükkmogyorósd: Csurgó, Teresztyén; Hevesaranyos: Gyilkos-tető, Köszörűs, Ürge-lápa; Uhg: Borsodbóta: Tó-padja, Vatos; Dédestapolcsány: Éles-kő, Halabuka-tető, Hosszú-berek-tető, Kerek-domb, Kukorica-föld, Nagy-hegy (SJ), Nagy-hegy-alja, Nagy-hegyi-szőlő, Nagy-hegy-orom, Varjas-szőlő; Nekézseny: Avasbérc (BÅ), Nagy-mál-tető, Szőlő-mál-tető; Sáta: Hosszak és Kéri-tó; Uppony: Csipeles-domb, Dedevár (SJ), Eszkála-tető (BÁ), Fekete-kő-tető, Kalica-tető (SJ), Macskás (BÁ), Upponyiszoros, Vízköz-szoros (SJ); Tv: Borsodnádasd: Karácsony-hegy (BÁ), Karácsonylova (SI); Borsodszentgyörgy: Kígyós-hegy; Domaháza: Aszaló-Bikk, Asztag-völgy-hegy, Kis-Ortvány, Mihály-tető, Petyke-bérc, Utas-fő; Hangony: Egres-oldal, Felső-kő-völgye, Meggyes-tető, Ortás-lápa-orom, Nagy-Ragyvás, Pogányvár; Istenmezeje: Nagy-Musák (BÁ); Járdánháza: Köves-hegy (SJ); Ózd: Bika-pad, Harmaci-völgy, Harmaci-völgy-fő, Nagy-oldal, Szőr-lápa, Zsófi János; Pétervására: Dudar-hegy, Vaskapu; Tarnalelesz: Henc-ortvány; Váraszó: Tó-hegyese; 
Zabar: Kenderes (BÁ); Óm: Borsodnádasd: Szalinca (SJ); Pm: Bükkszenterzsébet: Szőlőmegi-hegy; Erdőkövesd: Öv-hegy (BÁ); Fedémes: Árpaszó-hegy, Meggyes-oldal; Hevesaranyos: Bodony-árnyék, Dobogó-tető, Kis-Ecser, Kis-verő, Kőröspuszta, Sirokaszó; Tarnalelesz: Fingászó-hegy-orma, Madarászó, Nagy-hegyesse, Tormás-hegy (SJ); Váraszó: Békalyuk-orom, Gödrösi, Hereg-vár, Nagy-gödör, Ó-hegy, Öv-hegy, Szőlő-megi-hegy, Szőlő-megioldal, Vagdaszó-bérc (BÁ); Uh: Arló: Bagó-lápa, Ladány-tető, Lőrinc-árnyéka, Pocsi-bérc, Szohony; Borsodbóta: Őr-hegy (SJ); Borsodnádasd: Balatoni-tető, Budaberke, Dér-tető - a Dér-tanyától délre lévő 358,6 m-es hegy, Mocsolyás-tető, Vásáros-úti-völgy (BÁ); Csernely: Ali-út-tető, Alsó-Nyékes (SJ), Csiga-hajas-oldal - a Tólápától délre eső gerinc déli, csernelyi oldala (BÁ), Ecetes-Tök, Mák-völgy, Nemecke, Nyékes-tető, Pete-fia (SJ); Csokvaomány: Andornak, Kőbánya-hegyese (BÁ), Liba-tető (SJ), Szilfás, Vén-szőlő; Farkaslyuk: Kígyós; Járdánháza: Mocsolyás (BÁ), Mocsolyás-völgy, Szalinca (SJ), Tó-pad (BÁ); Sajómercse: Adárbérc, Gógány, Kerek-rét, Szarvaskút, Szörnyü-völgy, Tarkai-parlag (SJ); Sajónémeti: Rátos (BÁ). CEU: [7786.4], [7787.1], [7787.3], [7788.1], [7788.3], [7788.4], [7886.2], [7886.3], [7887.1], [7887.2], [7887.3], [7887.4], [7888.1], [7888.2], [7888.3], [7986.2], [7986.3], [7986.4], [7987.1], [7987.3], [8087.2].

1008. Geranium phaeum L. - Égerligetekben és üde - általában völgyközeli - bükkösökben és gyertyánelegyes erdőkben. Uhg: Dédestapolcsány: Balta-tető, Éger-alja (BÁ), Halabukatető; Nekézseny: Csernely-patak-völgye; Sáta: Csernely-patak-völgye; Uppony: Csernelypatak-völgye; Tv: Arló: Barlang-tető - a Nagy-hát-Sertéstől északra eső hosszú gerinc (SJ), Nagy-Nádú-völgy (BÁ), Palina-völgy, Remete-völgy, Vészverés-völgy - a Halonna-bérctől nyugatra eső völgy; Borsodszentgyörgy: Palina-völgy, Vizes-völgy (SJ); Hangony: Birinyvölgy (BÁ), Hangonyi-Renget-völgy (SJ), Kis-Golotka-völgy (BÁ), Mogyorós-verő (SJ), NagyGolotka-völgy, Renget-völgy, Szoros-völgy; Ivád: Zámor-völgy (BÁ); Kissikátor: Rengetvölgy (SJ); Pétervására: Szénégető-völgy; Tarnalelesz: Futyó-völgy (BÁ); Váraszó: Gemeruta-bérc (SJ), Hosszú-völgy, Kis-Ves-völgy, Musák-hegyes, Váraszói-völgy; Uh: Borsodnádasd: Vásáros-úti-völgy (BÁ). CEU: [7786.4], [7787.3], [7788.4], [7886.2], [7886.4], [7887.1], [7887.3], [7887.4], [7888.2], [7986.1], [7986.2], [7986.3].

1010. Geranium palustre E. Torner - Égerligetek kiritkuló részein, szegélyeiben, magassásosokban, üde magaskórósokban, patakparti szegélynövényzetben. Néhol állományalkotó. Uhg: Nekézseny: Felső-völgy; Tv: Arló: Remete-völgy (SJ), Vészverés-völgy (BÁ); Borsodnádasd: Szőlő-bérc-tető; Borsodszentgyörgy: Kalitka-völgy; Cered: Utas-patak-völgye; Domaháza: Benedek-völgy, Hintós-völgy, Nagy-völgy, Tó-völgye-patak; Hangony: Petyke-völgy; Váraszó: Molnár-lápa (SJ), Verő-lápa; Zabar: Szekeres-bükk-völgy - a Szekerestől északra eső völgy (BÁ); Uh: Arló: Bagó-lápa, Konnya-völgy (SJ); Borsodnádasd: Budaberki-völgy (BÁ); Csernely: Nagy-Horsó-völgy; Csokvaomány: Nemecke-árnyék; Királd: Királd-patak; Sajómercse: Királd-patak; Sajónémeti: Királd-patak (SJ). CEU: [7786.4], [7788.1], [7886.1], [7886.2], [7886.3], [7886.4], [7887.1], [7887.2], [7887.3], [7887.4], [7888.1], [7888.2].

1013. Geranium lucidum L. - Üde, árnyas sziklaerdőben. Az Upponyi-hegységből az első adat Budai Józseftől származik az Upponyi-szorosból (BuDAI ap. Soó 1943), amelyet Beránek Ábel erősít meg 2005-ben (BERÁNEK 2007). Uhg: Uppony: Eszkála-tető (SJ). CEU: [7788.4].

1014. Geranium columbinum L. - Tv: Borsodszentgyörgy: Palina-völgy - $\underline{\text { Herb.: }}$ 2005.10.18. - földút mentén ritka (BÁ). CEU: [7887.1].

1018. Geranium divaricatum Ehrh. - Tv: Pétervására: Lyukas-kő-hegy - $\underline{H e r b .: ~ 2009.6 .7 . ~-~}$ bolygatott cseres-tölgyesben (BÁ). CEU: [7986.3].

1027. Linum catharticum L. - Üdébb mészkerülő gyepekben, mohás északias kitettségű sziklagyepekben. Uhg: Uppony: Macskás, Vízköz-szoros - Herb.: 2009.5.26.; Tv: Domaháza: Aszaló-Bikk, Körte-lápa, Kovács-bérc, Kovács-ortványa-fő, Nehák, Vízálló-hegy - Herb.: 2009.6.13. (BÁ). CEU: [7788.4], [7886.2]. 
1030. Linum flavum L. - Szálkaperjés réteken, néhol jelentős egyedszámban. Bh: Bátor: Boza; Uhg: Borsodbóta: Gyűre, Menyhárt, Tó-padja; Dédestapolcsány: Kerek-domb, Köszörűs és varjas; Sáta: Kotyindó-tető (SJ); Óm: Ózd: Borbás-hegy (BÁ), Szilas-alja-hegyese; Pm: Fedémes: Alsó-sóska-hely, Árpaszó-hegy, Víg István-tető; Hevesaranyos: Bodony-árnyék, Kaptás; Tarnalelesz: Fingászó-hegy-orma, Kastály-legelő; Uh: Csernely: Borjúmáj (SI); Csokvaomány: Vén-szőlő; Farkaslyuk: Kígyós (BÁ); Sáta: Őr-hegy (SJ). CEU: [7787.3], [7787.4], [7788.3], [7887.2], [7888.1], [7888.2], [7986.4], [7987.3], [7987.4].

1031. Linum tenuifolium L. - Felnyíló szálkaperjés rétek Inula ensifolia-ás és Carex humilises típusaiban karakteres, de megjelenik sziklagyepekben és útrézsűkben is. Bh: Bátor: Boza, Megyaszó-fő; Bekölce: Láz, Perekonya-bérc; Borsodnádasd: Láz; Bükkmogyorósd: Teresztyén; Egercsehi: Kallaku, Szőlő-mála; Hevesaranyos: Gyilkos-tető, Ürge-hegy, Vereshegy; Mikófalva: Mesgye-dűlő; Uhg: Borsodbóta: Tó-padja; Dédestapolcsány: Bárci-tető, Éles-kő, Halabuka-tető, Hosszú-berek-tető (SJ), Nagy-hegy-alja, Nagy-hegyi-szőlő, Varjasszőlő; Nekézseny: Avas-bérc (BÁ), Nagy-mál-tető, Szőlő-mál-tető; Sáta: Kotyindó-tető; Uppony: Eszkála-tető, Fekete-kő-tető, Kalica-tető, Vízköz-szoros; Tv: Arló: Közép-Poporó (SI); Borsodnádasd: Karácsony-hegy, Kerek-berek-fő (BÁ), Róna-Bükk (SJ); Borsodszentgyörgy: Kígyós-hegy; Bükkszenterzsébet: Nagy-kő; Domaháza: Aszaló-Bikk, Asztag-völgy-hegy, Csurgó-bérc (BÁ), Hintós-tető - a Jós-Ortvány-tető déli 301,8 m-es gerince, Jós-Ortványtető, Kis-kút és Utas-völgy, Körte-tető - a Körte-völgytől északnyugatra eső 337,6 m-es hegy (SJ), Kovács-bérc (BÁ), Medvés-oldal, Mihály-homloka (SJ), Mihály-tető (BÁ), Petykebérc, Répás-verő, Szörnyű (SJ), Telek-felé (BÁ), Vízálló-hegy (SJ); Hangony: Felső-kő-völgye (BÁ), Kis-berek-bérc, Mihászó-orom (SJ), Pogányvár; Istenmezeje: Nagy-Musák (BÁ); Kissikátor: Renget-verő; Ózd: Meleg-oldal, Pásztor-kert-fő (SJ); Pétervására: Dudar-hegy, Remete-vár, Szalonnás-fó, Vaskapu (BÁ); Sajópüspöki: Csépány, Meleg-völgy (SJ); Tarnalelesz: Henc-ortvány; Váraszó: Tó-hegyese; Zabar: Östvény-tető (BÁ); Óm: Borsodnádasd: Sülyevölgyi-bérc, Szalinca (SJ); Ózd: Borbás-hegy (BÁ), Szilas-alja-hegyese, Szilas-tető (SI); Pm: Erdôkövesd: Öv-hegy, Új-hegy (BÁ); Fedémes: Aranyosi-oldal, Árpaszó-hegy, Felső-sóskahely, Kútos-tető, Meggyes-lápa, Meggyes-oldal; Hevesaranyos: Kaptás, Kis-verő, Víg Istvántető (SJ); Pétervására: Kepes-föld (BÁ); Szentdomonkos: Tormás-hegy; Tarnalelesz: Dancsok, Dancsok-far (SJ), Dugzó-oldal (BÁ), Fingászó-hegy-orma, Háromszög-far, Kastálylegelő (SJ), Kovács-had (BÁ), Lóhát-orom, Meszes, Nagy-hegyesse, Tormás-hegy (SI); Váraszó: Béka-lyuk-orom, Gödrösi, Hereg-vár, Ó-hegy, Öv-hegy, Szőlő-megi-hegy (BÁ); Uh: Arló: Konnya, Ladány-tető, Lőrinc-árnyéka, Pocsi-bérc, Szohony (SJ); Balaton: Varjas; Borsodbóta: Csépány-tető; Borsodnádasd: Balatoni-tető, Budaberke, Mocsolyás-tető (BÁ); Csernely: Borjúmáj, Nemecke, Palánt-tető; Csokvaomány: Babos (SJ), Kis-Omány-oldal, Kőbánya-hegyese (BÁ), Pap-hegyese, Vasút-tető; Sajómercse: Kisbikk, Körtvélyes, Nagy-hegy, Nyúzó-völgy, Ôr-tető (SJ); Sajónémeti: Aszó-tető, Rátos, Vár-hegy; Sáta: Bükkfő, Csépányberek, Liba-hegy (BÁ). CEU: [7786.4], [7787.1], [7787.3], [7787.4], [7788.1], [7788.3], [7788.4], [7886.1], [7886.2], [7887.1], [7887.2], [7887.3], [7887.4], [7888.1], [7888.2], [7888.3], [7986.2], [7986.3], [7986.4], [7987.1], [7987.2], [7987.3], [7987.4], [8087.1].

1032. Linum hirsutum L. - Szálkaperjés réteken, bolygatott száraz gyepekben, parlagokon, útrézsűkben gyakori. Bh: Bátor: Boza; Bekölce: Nagy-Marjaszó, Perekonya-bérc; Bükkmogyorósd: Salamon-vár; Csernely: Bazsik; Egercsehi: Kallaku; Hevesaranyos: Gyilkos-tető, Kopasz-orom, Nagy-lápa, Ürge-hegy, Ürge-lápa, Veres-hegy; Szúcs: Csehi-bérc; Uhg: Bánhorváti: Hosszú-berek, Máli-oldal; Borsodbóta: Menyhárt, Tó-padja; Sajómercse: Mercseágazat; Sáta: Kotyindó-tető; Tv: Borsodnádasd: Karácsonylova, Kerek-berek-fő; Borsodszentgyörgy: Kis-asza-fő, Razaj (SJ); Domaháza: Aszaló-Bikk, Bükk-tető, Csurgó-bérc (BÁ), Felső-völgy, Gyusz-tető - a Gyusz-völgyet körülölelő 336,2 m-es hegy, Hintós-tető, JósOrtvány-tető, Kis-kút és Utas-völgy, Körte-tető (SJ), Kovács-bérc (BÁ), Medvés-oldal, Mihály-homloka (SJ), Mihály-tető, Örvényes (BÁ), Petyke-bérc, Répás-verő (SJ), Szörnyű (BÁ), 
Tamás-tető - a Tamás-völgytől nyugatra található 355,9 m-es hegy (SJ), Telek-felé (BÁ), Utas-fő (SJ); Istenmezeje: Musák-hegyes (BÁ); Kissikátor: Renget-verő; Sajópüspöki: Csépány, Meleg-völgy; Szentdomonkos: Kő-hegy (SJ); Tarnalelesz: Henc-ortvány (BÁ); Óm: Borsodnádasd: Sülye-völgyi-bérc, Szalinca; Pm: Bükkszenterzsébet: Buk-násza, Káca-verő, Lő-láz, Róna (SJ); Erdőkövesd: Öv-hegy, Új-hegy (BÁ); Fedémes: Alsó-sóska-hely, Aranyosioldal, Meggyes-lápa; Hevesaranyos: Barci-far, Víg István-tető; Szentdomonkos: Kő-aljagödre, Kő-alja-hegy, Virág-vár; Tarnalelesz: Dancsok, Dancsok-far, Fingászó-hegy-orma, Gásztászó, Kastály-legelő, Nagy-hegyesse, Tormás-hegy (SJ); Váraszó: Barca Tamás, Heregvár (BÁ); Uh: Arló: Konnya, Konnya-völgy, Ladány-tető, Pocsi-bérc, Szohony; Borsodbóta: Őr-hegy (SJ); Borsodnádasd: Balatoni-tető (BÁ); Csernely: Borjúmáj, Nyékes-tető, Úszó-fő (SJ); Csokvaomány: Kőbánya-hegyese (BÁ), Liba-tető (SJ), Nemecke-árnyék; Farkaslyuk: Kígyós (BÁ); Sajómercse: Gógány, Körtvélyes, Mercse-patak-völgye, Nagy-hegy, Őr-tető (SJ); Sáta: Bükkfő, Liba-hegy (BÁ). CEU: [7786.4], [7788.1], [7788.3], [7788.4], [7886.1], [7886.2], [7887.1], [7887.2], [7887.3], [7887.4], [7888.1], [7888.3], [7986.2], [7986.4], [7987.1], [7987.2], [7987.3], [7987.4], [8087.1].

1034. Linum austriacum L. - Száraz gyepekben, sztyepréteken szórványos. Uhg: Borsodbóta: Tó-padja; Nekézseny: Nagy-mál-tető; Sáta: Hosszak és Kéri-tó (SI); Tv: Hangony: Megygyes-tető, Mihászó-orom, Nagy-Ragyvás; Zabar: Kő-verő-hegy; Pm: Erdőkövesd: Fehéragyag-dúlő - Herb.: 2008.5.5. (BÁ); Fedémes: Kútos-tető; Uh: Csernely: Ecetes-Tök; Csokvaomány: Babos, Belterület, Liba-tető, Páter-oldal (SI), Vén-szőlő (BÁ). CEU: [7786.4], [7787.3], [7886.3], [7887.4], [7888.1], [7888.3], [7986.4], [7987.3].

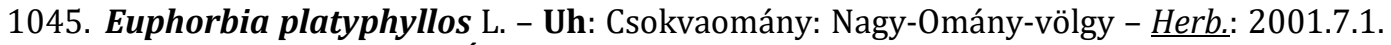
- száraz völgyalji gyepben (BÁ). CEU: [7888.1].

1049. Euphorbia glareosa Pall. - Löszös homokkő málladékon kialakult sztyepréteken és szálkaperjés réteken csak a Pétervásárai-medence keleti peremén lévő dombokon. Az Északi-középhegységben ritka fajnak az első észlelése Kitaibeltől származik (LőKös 2001), majd Soó 1937 említi a Mátraaljáról. Újabb előfordulásai a Mátra északi és déli előteréből kerültek elő Vizslás és Ecséd mellől (SRAMKó et al. 2008). A Tarnavidékről eddig nem volt ismert. Pm: Fedémes: Árpaszó-hegy, Meggyes-oldal; Hevesaranyos: Buja-hegy, Mocsolyásrét; Tarnalelesz: Lóhát-orom, Meszes (SJ). CEU: [7986.4], [7987.3].

1052. Euphorbia epithymoides L. - Melegkedvelő tölgyesekben. Bh: Hevesaranyos: Vereshegy; Uhg: Borsodbóta: Tó-padja; Dédestapolcsány: Balta-tető, Bender-bérc, Éles-kő, Sároldal; Nekézseny: Zsellér-földek; Uppony: Dedevár, Eszkála-tető, Három-kő, Kalica-tető, Vízköz, Vízköz-szoros; Tv: Arló: Közép-Poporó, Pados-bérc, Remete-bérc (SJ); Ózd: Sóskúttető (BÁ). CEU: [7787.2], [7788.3], [7788.4], [7887.1], [7887.3], [7888.2], [7987.3].

1070. Dictamnus albus L. - Melegkedvelő tölgyesekben, bokorerdőkben. A Pétervásáraimedence peremén lévő állományok erdőssztyep-erdő maradványokban. BENEDEK \& ZAY (1987) adata is az ezek közelében lévő Köröspuszta mellől származik. Bartha Csaba már jelzi a fajt 2004-ben a flóratérképezési program során a 7787.2-es kvadrátból, Ózd helynévvel [1]. Uhg: Bánhorváti: Éles-kő; Dédestapolcsány: Éles-kő (SJ); Uppony: Fekete-kőtető, Kalica-tető; Tv: Ózd: Sóskút-tető völgy - $\underline{\text { Herb.: }}$ 2012.5.6., (BÁ); Pm: Hevesaranyos: Buja-hegy; Tarnalelesz: Csigdászó, Lóhát-orom (SJ). CEU: [7787.2], [7788.4], [7986.4].

1073. Ailanthus altissima (Mill.) Swingle - Szárazabb gyepekben néhány sarjtelep. Uhg: Dédestapolcsány: Lipóc - lombelegyes telepített lucfenyvesben, alászorult sarjhajtások (SJ); Tv: Hangony: Felső-kő-völgye; Uh: Borsodbóta: Nagy-cihár (BÁ). CEU: [7786.4], [7788.3], [7888.2].

1074. Polygala major Jacq. - Szálkaperjés gyepek karakterisztikus, gyakori faja, amely néha megjelenik enyhén mészkerülő gyepekben is. Bh: Bátor: Szónya; Bükkmogyorósd: Alsósűrű-lápa, Csepegő-bérc - a Salamon-vártól nyugatra lévő 385,3 m-es hegy, Nagy-bérc - a Nagy-völgytől keletre lévő 330,2 m-es gerinc, Salamon-vár, Salamon-vár-alja - a Salamon- 
vártól északra lévő 361,1 és 343 m-es dombok; Csernely: Bazsik; Uhg: Bánhorváti: Bárcioldal, Hosszú-berek, Máli-oldal; Borsodbóta: Epres-mál, Gyüre, Gyüre-völgy - a Veresdombtól keletre lévő völgy, Menyhárt, Tó-padja, Vatos, Veres-domb, Veres-tető; Dédestapolcsány: Balta-tető, Bárci-tető, Halabuka-tető (SJ), Hosszú-berek-tető (BÁ), Köszörűs és varjas, Kukorica-föld, Mocsolya, Nagy-hegy-alja (SJ), Nagy-hegyi-szőlő, Nagy-hegy-orom, Varjas-szőlő; Nekézseny: Avas-bérc (BÁ), Nagy-mál-tető (SJ), Sordé-tető (BÁ), Szégyen-tető, Szőlő-mál-tető; Sajómercse: Mercse-ágazat; Sáta: Hosszak és Kéri-tó, Kotyindó-tető, Pipishegy, Szőlő-gyakra (SJ); Uppony: Kerecke-gödre, Upponyi-szoros (BÁ), Vízköz-szoros; Tv: Borsodnádasd: Karácsonylova, Pap-lápa (SJ); Borsodszentgyörgy: Palina-puszta; Ózd: Bikapad, Sóskút-tető (BÁ); Pm: Fedémes: Kútos-tető; Hevesaranyos: Sirokaszó (SJ); Uh: Balaton: Varjas; Borsodbóta: Csépány-tető (BÁ), Kerek-rét (SJ); Borsodnádasd: Budaberke, Mocsolyás-tető (BÁ); Csernely: Borjúmáj (SJ), Csiga-hajas-oldal (BÁ), Ecetes-Tök, Eperjes, Gárdony-tető, Mák-völgy, Nemecke, Papharaszt, Úszó-fő (SJ); Csokvaomány: Andornak (BÁ), Babos, Liba-tető, Nyékes-tető, Palánt-tető, Pap-hegyese (SJ); Farkaslyuk: Kígyós; Járdánháza: Mocsolyás, Tó-pad (BÁ); Királd: Őr-tető; Sajómercse: Adár-bérc, Gógány, Kerekrét, Körtvélyes, Mercse-patak-völgye, Nagy-hegy, Nyúzó-völgy, Őr-hegy, Őr-tető, Tarkaiparlag (SJ); Sajónémeti: Aszó-tető, Rátos (BÁ); Sáta: Őr-hegy, Zsineg (SJ). CEU: [7786.4], [7787.2], [7787.3], [7788.1], [7788.3], [7788.4], [7886.2], [7887.2], [7887.3], [7887.4], [7888.1], [7888.2], [7888.3], [7986.4], [7987.3], [8087.2].

1082. Acer negundo L. - Tv: Tarnalelesz: Pataj-völgy - egy idősebb fája erdőgazdasági út mentén (BÁ). CEU: [7886.4].

1083. Acer tataricum L. - Cseres és melegkedvelő tölgyesekben szórványos. Bh: Hevesaranyos: Gyilkos-tető, Köszörűs; Uhg: Bánhorváti: Bárci-oldal; Dédestapolcsány: Éles-kő, Éleskő-tető (SJ), Halabuka-tető (BÁ), Hosszú-berek-tető, Lipóc, Malom-hegyese, Nagy-hegy, Nagy-hegyi-szőlő (SJ); Nekézseny: Bánya-oldal (BÁ), Zsellér-földek; Uppony: Dedevár (SJ), Eszkála-tető (BÁ), Kalica-tető, Lázbérci-víztároló, Vízköz; Tv: Domaháza: Togonya; Pm: Fedémes: Kútos-tető; Tarnalelesz: Gásztászó, Kastály-legelő; Uh: Sajóvelezd: Vár-erdő (SJ). CEU: [7788.2], [7788.4], [7886.1], [7888.2], [7987.3], [8087.2].

1090. Impatiens parviflora DC. - Égerligetekben, bükkösökben, üdébb lomberdőkben. Uhg: Dédestapolcsány: Sár-oldal; Nekézseny: Fehér-kő; Tv: Hangony: Biriny-völgy; Ivád: Szentvölgy (BÁ). CEU: [7786.4], [7788.4], [7888.2], [7986.3].

1091. Impatiens glandulifera Royle - Patakmenti növényzetben szórványos. Uhg: Nekézseny: Csernely-patak-völgye, Felső-völgy (SJ); Óm: Ózd: Uraj-patak-völgy (BÁ). CEU: [7787.4], [7888.2].

1098. Staphylea pinnata L. - Szurdokerdőkben és bükkösökben szórványos. Uhg: Uppony: Upponyi-szoros; Tv: Arló: Keserűi-völgy - a Keserú-oromtól északkeletre eső völgy - $\underline{\text { Herb. }}$ : 2011.4.27.; Uh: Borsodnádasd: Csiterkötő, Csiterkötő-tető (BÁ). CEU: [7788.4], [7887.3], [7887.4].

1102. Frangula alnus Mill. - Üdébb elegycserjések, valamint patakmenti égerligetek (Hangony, Királd) növénye. Bh: Bekölce: Nagy-berek, Róna-bérc; Uhg: Dédestapolcsány: Malomhegyese - Herb.: 2008.6.21.; Nekézseny: Bánya-oldal; Uppony: Upponyi-szoros; Tv: Hangony: Biriny-völgy; Ózd: Szőr-lápa, Zsófi János; Uh: Királd: Királd-patak - Herb.: 2016.5.25. (BÁ). CEU: [7786.4], [7787.1], [7788.3], [7788.4], [7888.2], [7987.2].

1121. Lavatera thuringiaca L. - Sztyepréteken. Uhg: Dédestapolcsány: Lázbérci-víztároló (SJ); Óm: Ózd: Borbás-hegy (BÁ); Pm: Tarnalelesz: Lóhát-orom (SJ). CEU: [7787.4], [7888.2], [7986.4].

1129. Abutilon theophrasti Medik. - Erdőgazdasági utak mentén, degradáltabb részeken. Tv: Arló: Vajda-vár-völgy; Bükkszenterzsébet: Erzsébeti-völgy; Váraszó: Nagy-Ves, NagyVes-völgy - Herb.: 2007.8.18. (BÁ). CEU: [7887.3], [7986.2]. 
1130. Hibiscus trionum L. - Földutakon, szántóföldek szélén. Pm: Pétervására: Alsó-lázidû́lő; Uh: Csokvaomány: Nemecke-árnyék, Szilfás (BÁ). CEU: [7888.1], [7986.4].

1134. Daphne mezereum L. - Bükkösökben ritka. Tv: Arló: Kis-Nádú-fő, Kis-Poporó, Szedres-ág-bérc (SJ). CEU: [7887.1], [7887.3].

1135. Thymelaea passerina (L.) Coss. et Germ. - Nyíltabb száraz gyepek növénye. Néhol földutak mentén is. Tv: Bükkszenterzsébet: Köves-verő; Tarnalelesz: Henc-ortvány, Pm: Tarnalelesz: Kovács-had (BÁ), Tormás-hegy (SJ); Uh: Borsodnádasd: Csiterkötő (BÁ); Csernely: Borjúmáj; Sajómercse: Körtvélyes, Szarvaskút (SJ). CEU: [7788.3], [7887.4], [7888.1], [7986.2], [7987.1].

1137. Elaeagnus angustifolia L. - Tv: Hangony: Egres-oldal - őshonos fajokkal elegyes cserjést alkot délies kitettségű száraz füves domboldalon (BÁ). CEU: [7787.3].

1142. Hypericum tetrapterum Fr. - Magassásosokban, forráslápokban, forrásnövényzetben. Tv: Domaháza: Miklós-fája, Nagy-völgy, Son-torok; Hangony: Kortvány-völgy - a Kortvány-Magas-hegy vonulattól nyugatra eső völgy, Mihászó-völgy - a Mihászótól északra eső völgy; Uh: Arló: Arlói-tó (SJ). CEU: [7787.3], [7886.2], [7887.2].

1145. Hypericum hirsutum L. - Tv: Váraszó: Hosszú-ág-lápa - üde mészkerülő bükkösben (BÁ). CEU: [7886.4].

1147. Hypericum montanum L. - Mészkerülő bükkösök növénye. Bh: Borsodnádasd: Bánya-fölött - Herb.: 2008.7.12. (BÁ); Uhg: Uppony: Zsellér-földek (SJ); Tv: Istenmezeje: Völgy-árnyék-bérc; Váraszó: Demeterek (SJ); Óm: Borsodnádasd: Karácsonylova-völgy, Uh: Borsodnádasd: Budaberki-völgy (BÁ). CEU: [7886.3], [7886.4], [7887.3], [7887.4], [7888.2], [7987.2].

1148. Hypericum elegans Stephan ex Willd. - Uhg: Uppony: Upponyi-szoros - Herb.: 1934.7.7. (BP-437428); BoRos (1938) adatának megerősítése, aki a szoros északra néző sziklás oldalában gyüjtötte. 2013-ban három ponton 19 egyede került elő ugyanott nyúlfarkfüves sziklagyepben (SJ). Az Északi-középhegységben igen ritka [1], aktuális adatai még a bódvarákói Esztramosról (VoJTKó 2008) és a Zempléni-hegységből, Abaújszántó határából (PifKó et al. 2003), a tokaji Nagy-Kopaszról (Sulyok József, 2005 ined.), a Mátrából (BusCHMANN 2013), valamint a bükki Bélkőről (BoRos 1934, 1938, 1959, VojTKó 2001) vannak, ahol az északias kitettségü Sesleria-s sziklagyepekben nem ritka. CEU: [7788.4].

1156. Viola mirabilis L. - Uhg: Uppony: Vízköz - gyertyános-tölgyesben 10 egyed (SJ). CEU: [7788.4].

1159. Viola ambigua Waldst. et Kit. - Löszös homokkő málladékon kialakult szálkaperjés réteken, sztyepréteken. Óm: Borsodnádasd: Szalinca (SJ); Ózd: Borbás-hegy - Herb.: 2007.3.31. (BÁ); Pm: Hevesaranyos: Buja-hegy; Uh: Sajóvelezd: Lapos-kő alja (SJ). CEU: [7787.4], [7788.2], [7887.4], [7986.4], [7987.3].

1160. Viola rupestris F.W. Schmidt - Szálkaperjés félszáraz gyepekben. Bh: Hevesaranyos: Ürge-hegy, Ürge-lápa, Veres-hegy; Tv: Borsodnádasd: Karácsonylova; Járdánháza: Köveshegy; Óm: Ózd: Akasztó-domb; Pm: Fedémes: Aranyosi-oldal, Meggyes-oldal; Uh: Csernely: Lukács Gergelyesse, Nemecke, Pete-fia (SJ). CEU: [7787.3], [7887.2], [7887.3], [7987.3].

1162. Viola riviniana Rchb. - Bükkösökben, gyertyános-tölgyesekben szórványos. Bh: Hevesaranyos: Gyilkos-tető, Veres-hegy; Tv: Borsodszentgyörgy: Patak-völgy (SI). CEU: [7887.1], [7987.3].

1167. Helianthemum canum (L.) Hornem. - A hegységből Budai József gyüjtötte először (1912.5.5. - BP-115852) az Upponyi-szorosból (BuDAI 1914). Később Zólyomi Bálint (ZóLYOMI 1928), Boros Ádám (BoROS 1934), Vojtkó András (1991.8.8. - BP-756338) (VojтKó 1994, 1995, 2001), és Beránek Ábel (2005.5.21. - BP-692298) erősítette meg az adatot. Uhg: Uppony: Kalica-tető - a szoroson kívüli mészkősziklagyepekben nem ritka (BÁ). CEU: [7788.4]. 
1169. Helianthemum ovatum (Viv.) Dunal in DC. - Tv: Hangony: Bajusz-tető - $\underline{\text { Herb. }}$ : 2005.5.15. - homokkő-sziklagyepben. (BÁ). CEU: [7787.3].

1170. Fumana procumbens (Dunal) Gren. et Godr. - Homokkő-sziklagyepekben ritka. A fajnak a Salgótarján környéki oligocén homokkőről (CSIKY at al. 1999, CSIKY 2004), a Tarnavidék déli részéről (BERÁNEK 2007, 2008), valamint Csokvaomány környékéről vannak adatai (Penksza Károly 2003 [1]). Tv: Pétervására: Dudar-hegy, Remete-vár (BÁ). CEU: [7986.3].

1189. Echinocystis lobata (Michx.) Torr. et A. Gray - Patakmenti égeres füzligetekben. Bh: Bátor: Laskó-völgy; Uhg: Nekézseny: Felső-völgy; Tv: Istenmezeje: Keskeny-bérc (SJ). CEU: [7886.3], [7888.2], [8087.2].

1225. Epilobium roseum Schreb. - Forrásnövényzetben szórványos. Tv: Arló: Gyepes-völgy - Herb.: 2004.8.24., a Remete-kútnál; Hangony: Üsnök - Herb.: 2004.9.8., az Üsnök-kútnál;

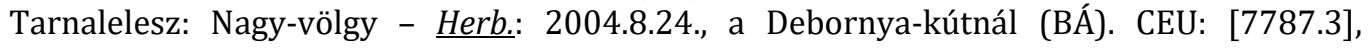
[7886.4], [7887.3].

1233. Cornus mas L. - Melegkedvelő erdőkben néhány egyed. A Tarnavidéken ritka cserje, melyet már VoJTKó \& SULYoK (2014) is megemlít. Tv: Ózd: Harmaci-völgy-fő, Szőr-lápa; Hangony: Nagy-kő-alatt (BÁ). CEU: [7787.1], [7787.3].

1241. Sanicula europaea L. - Üde bükkösökben és gyertyánelegyes erdőkben. A Tarnavidéken ritka. Tv: Arló: Gyöngy-ág-völgy; Tarnalelesz: Futyóköz-orma; Váraszó: Remete-fő a Borostyánostól délkeletre futó gerinc, Váraszói-völgy (BÁ). CEU: [7886.4].

1257. Bifora radians M. Bieb. - Szántókon és nyílt földfelszíneken. Néhol tömeges. A faj eddig az Upponyi-hegyhát területéről volt ismert (SULYOK \& SCHMOTZER 1999, BERÁNEK in MolnÁR et al. 2019). A Tarnavidékre és a Bükk-hátra új. Bh: Balaton: Nagy-völgy; Tv: Han-

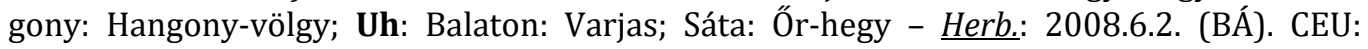
[7787.3], [7788.3], [7887.4].

1260. Pimpinella major (L.) Huds. - Üde gyepekben, erdőszegélyekben. Uhg: Sajómercse: Finta-völgy; Uppony: Vízköz; Uh: Sajómercse: Adár-völgy, Mercse-patak-völgye, Szörnyüvölgy (SJ). CEU: [7788.3], [7788.4].

1263. Sium latifolium L. - Mocsárréten szórványos. Tv: Hangony: Hangony-völgy - $\underline{\text { Herb. }}$ : 2013.8.27. (BÁ). CEU: [7787.3].

1265. Berula erecta (Huds.) Coville - Patakokban, forrásnövényzetben. Bh: Bükkmogyorósd: Csepegő-forrás; Uhg: Borsodbóta: Gyüre-völgy (SJ); Dédestapolcsány: Éger-alja; Tv: Borsodszentgyörgy: Palina-völgy, Üsnök-völgy (BÁ); Cered: Vörös-csáté-völgy (SI); Domaháza: Keselyús-Bikk-völgy (BÂ), Miklós-fája, Nagy-völgy, Son-torok (SJ), Sózó-völgy (BÁ); Hangony: Hangonyi-Renget-völgy (SJ), Kortvány-völgy (BÁ), Renget-völgy; Járdánháza: Cselény-völgy; Kissikátor: Renget-völgy (SI); Szentdomonkos: Hajagos-völgy (BÁ); Váraszó: Hosszú-völgy, Molnár-lápa, Verő-lápa (SJ); Zabar: Kő-verő-patak-völgye (BÁ); Pm: Tarnalelesz: Bolya-völgy; Uh: Arló: Csahó-völgy, Izra-völgy (SJ). CEU: [7786.4], [7787.3], [7788.3], [7886.2], [7886.3], [7886.4], [7887.1], [7887.2], [7888.2], [7888.3], [7986.4], [7987.1].

1266. Libanotis pyrenaica (L.) Bourg. - Száraz gyepekben helyenként gyakori. Uhg: Dédestapolcsány: Balta-tető, Halabuka-tető (BÁ), Kerek-domb, Köszörűs és varjas (SI), Nagy-hegy (BÁ), Nagy-hegy-alja, Nagy-hegyi-szőlő, Nagy-hegy-orom (SJ), Rigós-lápa, Sár-bérc (BÂ), Varjas-szőlő (SJ); Nekézseny: Avas-bérc; Uh: Sajómercse: Mercse-patak-völgye (SJ). CEU: [7788.3], [7888.2].

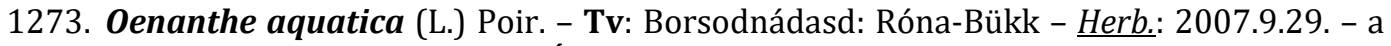
róna-bükki időszakos tó partján (BÁ). CEU: [7887.3].

1284. Bupleurum rotundifolium L. - Búzavetések szélén és száraz gyepekben szórványos. Bh: Balaton: Nagy-völgy - $\underline{\text { Herb.: }}$ 2008.6.14.; Pm: Erdőkövesd: Öv-hegy, Szőlőközi-völgy (BÁ); Fedémes: Fedémesi-patak-völgye (PD-SJ), Pétervására: Sírmány (BÁ). CEU: [7887.4], [7986.4], [7987.3]. 


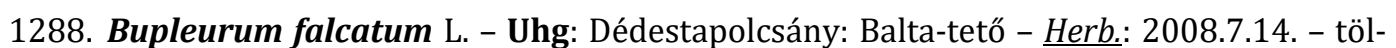
gyesben (BÁ). CEU: [7888.2].

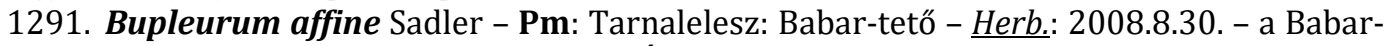
tető gerincén, kökényes gyepben ritka (BÁ). CEU: [7987.1].

1302. Selinum carvifolia L. - Üde mészkerülő réten és mocsárréten. Tv: Istenmezeje: Széporom (BÁ); Uh: Királd: Kerek-rét (SJ). CEU: [7788.3], [7986.1].

1307. Ferula sadleriana Ledeb. - Uhg: Uppony: Kalica-tető - Herb.: 2012.5.25., Upponyiszoros - mindkét helyen a turistaúthoz közeli sziklafüves lejtőkön 2012-ben 12, 2013-ban 1 tő. Valószínűleg betelepítés eredménye. Kalapos Tibor szerint az 1980-as években Seregélyes Tibor javaslatára történt magszórás a területen, de a jelenlegi lelőhelytől lentebb. Az akkori magszórás sikertelennek bizonyult, nem keltek ki növények (SL-SJ). A Ferula legközelebbi őshonos előfordulása a bükki Bélkőről ismert (BUDAI 1912, HULJáK 1933, ZóLYOMI 1934, Boros 1941, 1959, VojTKó \& MARSCHALL 1991, VojTKó 1994, 2001). CEU: [7788.4].

1312. Peucedanum alsaticum L. - Löszös száraz gyepben. Uhg: Bánhorváti: Varbó-oldal - a Bodó keleti, a település melletti gerince (BÁ). CEU: [7788.4].

1314. Peucedanum cervaria (L.) Lapeyr. - Sztyeprétek, cserjések, szegélynövényzet gyakori növénye. Uhg: Bánhorváti: Bodó, Varbó-oldal; Dédestapolcsány: Varjas-szőlő; Nekézseny: Avas-bérc; Uppony: Cibróka; Tv: Hangony: Egres-oldal; Pm: Erdőkövesd: Öv-hegy, Új-hegy; Uh: Borsodnádasd: Mocsolyás-tető; Csokvaomány: Árendás-oldal, Farkas-tető (BÁ). CEU: [7787.3], [7788.4], [7887.4], [7888.1], [7888.2], [7986.4].

1321. Laser trilobum (L.) Borkh. - Vojtkó András már jelzi a fajt 2004-ben a flóratérképezési program során a 7888.2-es kvadrátból, Dédestapolcsány helynévvel [1]. Uhg: Dédestapolcsány: Hosszú-berek-tető - cseres-tölgyesben 6 egyed (SJ). CEU: [7888.2].

1327. Caucalis platycarpos L. - Degradáltabb nyílt száraz gyepek és homokkő-sziklagyepek növénye. Uhg: Uppony: Eszkála-tető, Upponyi-szoros, Vízköz-szoros (SJ); Tv: Pétervására: Dudar-hegy; Tarnalelesz: Henc-ortvány, Ordas-kő - Herb.: 2001.5.19., Vermes-hát; Pm: Pétervására: Alsó-lázi-dúlő; Váraszó: Patakverej, Vagdaszó-bérc (BÁ). CEU: [7788.4], [7887.3], [7986.2], [7986.3], [7986.4], [7987.1].

1331. Pyrola minor L. - Üdébb mészkerülő bükkösökben vezető erdőgazdasági utak útrézsűiben, illetve a bükkösök szélein ritka. Tv: Domaháza: Kaszáló-padosa, Vörösvárihegyese; Istenmezeje: Görbe-fő, Hagymás-eleje, Hagymás-völgy; Váraszó: Csókás-völgy (BÁ), Demeterek (SJ), Fenekes-völgy, Kis-dél - a Kenyér-dombtól északkeletre eső 407,5 mes vonulat; Zabar: Széles-határ; Uh: Borsodnádasd: Csiterkötő-tető (BÁ). CEU: [7886.3], [7886.4], [7887.4], [7986.1].

1338. Monotropa hypopitys L. s. str. - Mészkerülő bükkösökben szórványos. Uhg: Uppony: Dedevár, Eszkála-tető, Vízköz; Tv: Arló: Elő-Poporó - a Kis-barlang-völgytől északkeletre eső 434,8 m-es hegy, Gyepes-völgy, Kis-barlang-bérc, Kis-Poporó, Nagy-barlang-völgy, Nagy-hát-Sertés, Nyír-völgy, Pataj-fö, Remete-bérc (SJ); Borsodnádasd: Karácsonylova (BÁ); Istenmezeje: Tamás telke-fó, Víz-lápa-fő, Völgy-árnyék-bérc; Váraszó: Csókás-hegy, Csókás-völgy, Fenekes, Hosszú-ágy, Kenyér-domb, Kerek-dél, Kis-dél, Zelemér; Uh: Arló: Macó-bérc (SJ). CEU: [7788.4], [7886.3], [7886.4], [7887.1], [7887.3], [7887.4].

1339. Monotropa hypophegea Wallr. - Uhg: Uppony: Zsellér-földek - mészkőtörmelékes bükkösben, Cephalanthera rubra és damasonium társaságában (SJ). CEU: [7888.2].

1348,2. Primula veris L. subsp. canescens (Opiz) Hayek - Cseres és gyertyános-tölgyesben.

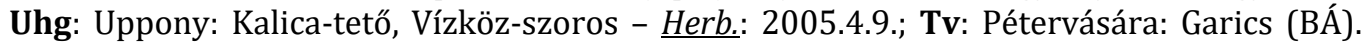
CEU: [7788.4], [7986.1].

1349. Primula elatior (L.) Hill - Főleg völgytalpi üde bükkösökben, égerligetekben, gyertyános-tölgyesekben. Tv: Arló: Barlang-tető, Géz-völgy, Gyepes, Halonna-bérc, Kerek-hegy, Kereszt-völgy, Körtvélyes, Közép-Poporó, Lencsényi-tető, Nádú-bérc, Nagy-Poporó, Nyilakó-völgy, Nyír-völgy, Pap-kút, Remete-bérc, Szedres-ág-bérc, Szúnyogos, Vészverés-bérc, 
Vészverés-csúcs, Virág-bérc - a Virág-völgytől nyugatra eső 411,2 m-es hegy, Vizes-lápabérc, Zár-fő, Zsá-völgy; Borsodszentgyörgy: Csanálos-bérc, Eszkála-bérc, Eszkála-tető, Felső-Ünök, Járnok-bérc, Kántor-lápa, Kémének-tető, Nagy-Kőte, Teresznek-far-tető, Vizesvölgy, Zár-rét; Kissikátor: Kis-Benedek, Szeles-lápa (SJ); Tarnalelesz: Futyóköz-orma, Pénzes-hegy (BÁ). CEU: [7886.2], [7886.4], [7887.1], [7887.3].

1372. Fraxinus ornus L. - Melegkedvelő és cseres-tölgyesekben, homokkő-sziklaerdőben, borókásokban elegyfaként. Néhol állományalkotó. Bh: Hevesaranyos: Ecser-hegy (SJ); Tv: Bükkszenterzsébet: Dobogó-bérc - $\underline{\text { Herb.: }}$ 2008.5.5.; Erdőkövesd: Gyepűs, Külső-hang-láza; Pétervására: Lyukas-kő, Nagy-Lyukas-kő; Tarnalelesz: Henc-ortvány, Pm: Tarnalelesz: Babar-tető - Herb.: 2008.8.30. (BÁ). CEU: [7986.1], [7986.2], [7986.3], [7987.1], [7987.3].

1384. Gentiana cruciata L. - Északias kitettségű szálkaperjés és mészkerülő gyepekben ritka. Bh: Bekölce: Nagy-Marjaszó, Perekonya-bérc; Hevesaranyos: Köszörüs; Uhg: Borsodbóta: Kotyindó-tető, Ragicca, Tó-padja; Uppony: Cibróka; Pm: Bükkszenterzsébet: Róna; Hevesaranyos: Bodony-árnyék; Tarnalelesz: Tormás-hegy (SJ); Váraszó: Ó-hegy, Öv-hegy, Títás; Uh: Csokvaomány: Farkas-tető (BÁ). CEU: [7788.3], [7788.4], [7888.1], [7986.2], [7986.4], [7987.1], [7987.2], [7987.3], [8087.2].

1393. Vinca minor L. - Gyertyános tölgyesekben, néha bükkösökben szórványos, de lokálisan tömeges is lehet. Bh: Bátor: Megyaszó-fő; Hevesaranyos: Dóna-útja-bérc, Dóna-verő; Uhg: Bánhorváti: Éles-kő-tető; Dédestapolcsány: Hosszú-berek-tető, Lipóc (SI); Tv: Cered: Szilas-patak-völgye; Hangony: Halyág-bérc, Kántor-verő (BÁ); Kissikátor: Fertő-lápa (SI); Ózd: Harmaci-völgy-fő, Tótok-erdeje; Sajópüspöki: Hosszú-tető - a Piszkor-főtől keletre eső 301,2 m-es hegy, Piszkor-fő (BÁ), Szurdok (SJ); Váraszó: Herceges (BÁ), Kenyér-domb, Kisdél (SJ), Köves-út (BÁ); Pm: Szentdomonkos: Nyárjas-lápa; Uh: Arló: Konnya-völgy; Csernely: Borsostartó-tető, Horsó-puszta (SJ); Ózd: Isten-hegy (BÁ). CEU: [7786.4], [7787.1], [7787.2], [7788.1], [7788.4], [7885.4], [7886.2], [7886.4], [7887.1], [7887.2], [7887.4], [7888.2], [7986.2], [7987.1], [8087.1].

1395. Asclepias syriaca L. - Elsősorban zavartabb száraz gyepekben, de néhol erdőgazdasági feltáróutak mentén és vágásokban is. Terjedőben! Tv: Domaháza: Aszaló-Bikk, Répásvölgy; Hangony: Kis-Tartalóca - a Kis-Tartalóca-völgy fölötti hegygerinc és annak végében lévő 309,7 m-es hegy; Pétervására: Lyukas-kő; Szentdomonkos: Hosszú-völgy, Kanszortványos (BÁ); Váraszó: Szénégető-hegyese; Óm: Arló: Szentgyörgyi-patak-völgye (SJ); Pm: Erdőkövesd: Öv-hegy, Szőlőközi-völgy; Pétervására: Alsó-lázi-dűlő; Váraszó: Hársas-lápa (BÁ); Uh: Arló: Szohony-völgy (SJ); Csokvaomány: Határ-völgy - a Határ-bérctől délre eső völgy (BÁ). CEU: [7787.3], [7886.1], [7886.2], [7886.4], [7887.1], [7887.2], [7888.1], [7986.2], [7986.3], [7986.4], [7987.1].

1412. Lithospermum officinale L. - Erdőszegélyekben, cserjésekben, száraz gyepekben. Bh: Hevesaranyos: Dakó-hegye, Ecser-hegy; Uhg: Dédestapolcsány: Balta-tető; Óm: Ózd: Akasz-

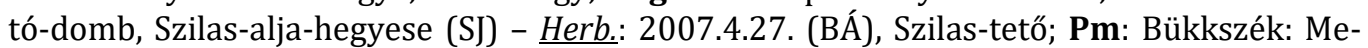
szes-dűlő; Hevesaranyos: Bodony-árnyék, Sirokaszó-fő; Tarnalelesz: Lóhát-orom, Madarászó (SJ). CEU: [7787.3], [7787.4], [7888.2], [7986.4], [7987.3], [8087.1].

1413. Buglossoides purpurocaerulea (L.) I.M. Johnston - Melegkedvelő tölgyesekben, erdőszegélyekben, cserjésekben, ritkábban száraz, köves gyepekben. Bh: Hevesaranyos: Berkenyés-verő, Ecser-hegy, Kopasz-orom, Veres-hegy; Uhg: Bánhorváti: Éles-kő-tető, Hosszúberek (SJ); Dédestapolcsány: Balta-tető (BÁ), Bender-bérc, Éles-kő, Éles-kő-tető, Halabukatető, Hosszú-berek-tető (SI), Nagy-hegy, Nagy-hegy-orom, Rigó-tető (BÁ), Sár-oldal, Varjasszőlő (SJ); Nekézseny: Avas-bérc (BÁ), Hármas-határ, Szőlő-mál-tető, Zsellér-földek; Uppony: Bender-oldal (SJ), Cibróka (BÁ), Dedevár, Eszkála-tető, Fekete-kő-tető (SJ), Kalicatető (BÁ), Upponyi-szoros, Vízköz, Vízköz-szoros, Zsellér-földek (SJ); Tv: Istenmezeje: Felső-Kajra-völgy; Ózd: Sóskút-tető - Herb.: 2012.5.6. (BÁ); Pm: Hevesaranyos: Kis-Ecser (SJ). CEU: [7787.2], [7788.4], [7888.1], [7888.2], [7986.1], [7987.3], [8087.1]. 
1416,2. Onosma arenaria Waldst. et Kit. subsp. tuberculata (Kit.) Jáv. - Nyíltabb homokkősziklás melegkedvelő tölgyesek, száraz gyepek és homokkő-sziklagyepek ritkább növénye. A növény pataj-verői adatát már CzÁJLIK (1989) is említi. Tv: Arló: Szeressza-völgy; Bárna: Ceredi-határ; Borsodszentgyörgy: Lyuk-hegy (SJ); Hangony: Pogányvár; Istenmezeje: Kőhártya-tető; Tarnalelesz: Pataji-far, Pataj-verő (BÁ). CEU: [7787.3], [7885.4], [7886.4], [7887.1], [7986.1].

1418. Cerinthe minor L. - Száraz gyepek növénye. Tv: Ózd: Prika-völgy, Szenna-tető; Pm: Bükkszenterzsébet: Hosszak; Váraszó: Öv-hegy; Uh: Csernely: Borjúmáj; Sajónémeti: Rátos, Vár-hegy (BÁ). CEU: [7787.3], [7787.4], [7788.1], [7888.1], [7986.2], [7986.4].

1422. Echium maculatum L. - Löszös-homokos talajú sztyepréteken és félszáraz gyepekben. Uhg: Borsodbóta: Vatos; Dédestapolcsány: Halabuka-tető (SI); Uppony: Szilas-tető (BÁ); Tv: Ózd: Pásztor-kert-fő (SJ), Óm: Ózd: Borbás-hegy (BÁ), Szilas-tető, Szil-tető; Pm: Hevesaranyos: Buja-hegy; Tarnalelesz: Lóhát-orom, Madarászó (SJ); Uh: Királd: Árok-oldal (BÁ). CEU: [7787.1], [7787.3], [7787.4], [7788.1], [7788.3], [7788.4], [7888.2], [7986.4], [7987.3].

1442. Myosotis caespitosa Schultz - Jó vízellátottságú mocsárréteken ritka. Az Északiközéphegységben csak a Mátrában és a Zemplénben találjuk aktuális adatait [1] (HARMOS \& SRAmKó 2000, Pelles in FARKAS 1999, SRAmKó et al. 2003). A Tarnavidékre új. Tv: Domahá-

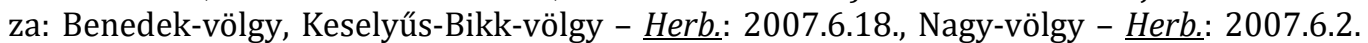
(BÁ). Cönológiai felvétel a Domaháza - Nagy-völgyi élőhelyen: felvétel ideje: 2016. május 29. és szeptember 23., kvadrátméret: $4 \times 4$ méter, tszf: $232 \mathrm{~m}$, GPS: $48,17160^{\circ} \mathrm{N} 20,10868^{\circ}$ E, gyepszint borítása: 100\%: 2-3: Juncus inflexus, Scirpus sylvaticus 1: Alisma lanceolatum s.l., Berula erecta, Caltha palustris subsp. laeta, Carex distans, Equisetum palustre, Lycopus europaeus subsp. europaeus, Mentha aquatica +-1: Carex otrubae, Cirsium canum, Galium uliginosum, Hypericum tetrapterum, Poa palustris, Potentilla anserina, Ranunculus repens +: Achillea collina, Angelica sylvestris, Epilobium parviflorum, Lychnis flos-cuculi, Mentha longifolia, Myosotis caespitosa, Rumex acetosa CEU: [7886.2].

1444. Myosotis scorpioides L. - Üde, időszakos vízborítású égerligetekben, patakokban. Tv: Hangony: Üsnök - $\underline{\text { Herb.: }}$ 2005.7.10.; Járdánháza: Cselény-völgy; Váraszó: Hosszú-rét Herb.: 2007.6.4. (BÁ). CEU: [7787.3], [7886.4], [7887.3].

1446. Myosotis sylvatica (Ehrh.) Hoffm. - Üde völgyközeli bükkösök növénye. Tv: Arló: Nagy-Nádú-völgy, Veres-csurgó-lápa; Hangony: Nagy-Golotka-völgy - Herb.: 2008.5.3; Tar-

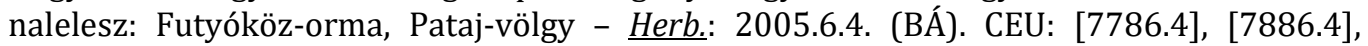
[7887.1], [7887.3].

1449. Myosotis sparsiflora J.G. Mikan - Égerligetek, bükkösök, degradált üde erdők gyakori növénye. Tv: Arló: Nagy-Nádú-völgy; Borsodszentgyörgy: Csanálos-völgy - $\underline{\text { Herb.: }}$

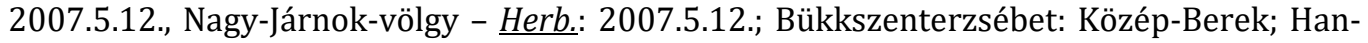
gony: Biriny-völgy, Hangonyi-Renget-völgy, Kis-Golotka-völgy, Nagy-Golotka-völgy, Rengetvölgy, Szeredvény-völgy, Szoros-völgy; Istenmezeje: Hagymás-völgy - Herb.: 2007.4.30.; Pétervására: Vaskapu - Herb.: 2007.4.30.; Tarnalelesz: Futyó-völgy, Nagy-völgy, Patajvölgy, Szék-fö-völgy, Vállós-völgy, Vermes-árnyék; Zabar: Zabar-völgy; Pm: Erdőkövesd: Tiszán-völgy (BÁ). CEU: [7786.4], [7787.3], [7886.2], [7886.3], [7886.4], [7887.1], [7986.1], [7986.2], [7986.3], [7986.4].

1455. Lappula squarrosa (Retz.) Dumort. - Homokkő-sziklagyepben. Tv: Szentdomonkos: Pusok - Herb.: 2016.5.20. (BÁ). CEU: [7987.1].

1456. Lappula heteracantha (Ledeb.) Borbás - Sziklagyepekben, ritka. Boros Ádám 1960. 8. 18-ai gyűjtőútján az Upponyi-szoros napos szikláin szedi (BoRos 1960). Uhg: Uppony: Fekete-kő-tető, Upponyi-szoros - $\underline{\text { Herb.: }}$ 1960.8.18. (BP-455065), Boros Ádám adatának megerősítése (SJ). CEU: [7788.4]. 
1470. Ajuga chamaepitys (L.) Schreb. - Nyílt száraz gyepekben ritka. Tv: Tarnalelesz: Hencortvány (BÁ); Pm: Fedémes: Kútos-tető (SJ); Váraszó: Hereg-vár, Szőlő-megi-oldal, Vagdaszó-bérc (BÁ). CEU: [7986.2], [7987.1], [7987.3].

1475. Teucrium montanum L. - Szálkaperjés, valamint nyíltabb száraz gyepek és homokkősziklagyepek gyakori növénye. Bh: Borsodnádasd: Láz; Uhg: Dédestapolcsány: Nagy-hegyorom; Tv: Borsodnádasd: Karácsony-hegy; Borsodszentgyörgy: Kígyós-hegy; Bükkszenterzsébet: Köves-verő, Vár-magas; Domaháza: Mihály-tető; Istenmezeje: Nagy-Musák; Pétervására: Remete-vár; Tarnalelesz: Henc-ortvány; Zabar: Kenderes; Pm: Bükkszenterzsébet: Szőlô-megi-hegy; Tarnalelesz: Babar-tető, Dugzó-oldal; Váraszó: Béka-lyuk-orom, Gödrösi, Öv-hegy, Vagdaszó-bérc; Uh: Csokvaomány: Kis-Omány-oldal; Farkaslyuk: Kígyós; Járdánháza: Pap-hegy; Sáta: Liba-hegy (BÁ). CEU: [7886.2], [7886.3], [7887.1], [7887.2], [7887.3], [7887.4], [7888.1], [7888.2], [7986.2], [7986.3], [7986.4], [7987.1], [7987.2].

1480. Scutellaria galericulata L. - Mocsárréteken ritka. Tv: Domaháza: Nagy-völgy, SzélesImola-völgy; Zabar: Zabar-völgy; Óm: Arló: Szentgyörgyi-patak-völgye (SJ). CEU: [7886.2], [7886.3], [7887.1].

1482. Scutellaria altissima L. - Erdőgazdasági utak mentén üdébb lomberdőkben, valamint gyertyános-tölgyesben és szurdokerdőben. A tájegységből SUBA (1969) közli egyetlen korábbi adatát Tarnalelesz mellől. Vojtkó András már jelzi a fajt 2004-ben a flóratérképezési program során a 7986.2-es kvadrátból, Váraszó helynévvel [1]. Bh: Fedémes: Répás-völgy BENEDEK \& ZAY (1987) Scutellaria columnae adatát keresve csak S. altissima-t került elő (SJ); Tv: Istenmezeje: Gyepü-lápa-laposa - Herb.: 2007.7.17., Kőhártya-tető - Herb.: 2008.6.1., Önyves-bérc - $\underline{\text { Herb.: }}$ 2007.5.18.; Váraszó: Hosszú-völgy (a Kis-Ves-völgy közelében), NagyMusák (BÁ). CEU: [7985.2], [7986.1], [7986.2], [7987.3].

1486. Sideritis montana L. - Nyíltabb száraz gyepekben. Uhg: Uppony: Eszkála-tető (SJ); Tv: Borsodnádasd: Kerek-berek-fő; Bükkszenterzsébet: Erzsébeti-völgy, Köves-verő; Domaháza: Csurgó-bérc, Kék-Ász-fő, Szörnyű (BÁ); Váraszó: Hosszú-völgy, Kő-orom (SJ); Zabar: Ments-árnyék, Zabar-völgy (BÁ); Óm: Ózd: Szil-tető (SJ); Pm: Bükkszenterzsébet: Káca-verő; Erdőkövesd: Új-hegy (BÁ); Fedémes: Árpaszó-hegy, Kútos-tető, Meggyes-oldal (SJ); Pétervására: Alsó-lázi-dúlő (BÁ); Tarnalelesz: Fingászó-hegy-orma, Tormás-hegy (SI); Váraszó: Vagdaszó-bérc (BÁ); Uh: Sajómercse: Nagy-hegy (SJ). CEU: [7787.3], [7788.3], [7788.4], [7886.1], [7886.2], [7886.3], [7887.3], [7986.2], [7986.4], [7987.1], [7987.3].

1487,2. Melittis melissophyllum L. s. l. subsp. carpatica (Klokov) P.W. Ball - Bükkösben és

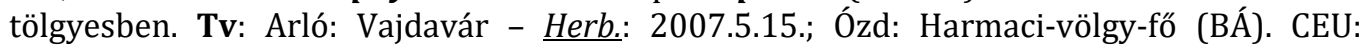
[7787.1], [7887.3].

1488. Phlomis tuberosa L. - Az Északi-középhegység déli előterében nem ritka fajnak ez az első előfordulása a dombvidéken. Pm: Hevesaranyos: Buja-hegy - löszös talajú sztyepréten $2 \mathrm{~m}^{2}$-es polikormon (SJ). CEU: [7987.3].

1511. Stachys palustris L. - Lápi magaskórósokban. Uh: Lénárddaróc: Alsó-hosszas - $\underline{H e r b}$ : 2006.7.29., Csokvaomány: Kis-Omány (BÁ). CEU: [7888.1].

1513. Stachys germanica L. - Tv: Tarnalelesz: Agyagos-hegyes - cseres-tölgyes menti gyepben (BÁ); Uh: Arló: Lőrinc-árnyéka - száraz gyepben egy tő (SJ). CEU: [7887.4], [7986.2].

1516. Nepeta pannonica L. - Erdőssztyep-erdő maradványban, erdőszegélyben ritka. A dombvidékről eddig nem ismert növénynek a legközelebbi adatai a Bükkből (VoJTKó 2001) és a Mátrából vannak (KÁRÁSZ 1991, MolnÁr 2001, 2002, SRAMKó et al. 2008). Bh: Bekölce: Perekonya-bérc; Pm: Tarnalelesz: Lóhát-orom, Meszes (SJ). CEU: [7986.4], [7987.2].

1519. Glechoma hirsuta Waldst. et Kit. - Bükkösben. Tv: Szilaspogony: Hidal-árnyék Herb.: 2017.4.11. (BÁ). CEU: [7886.3].

1524. Prunella grandiflora (L.) Scholler - Szálkaperjés gyepekben szórványos. Bh: Bátor: Boza; Bekölce: Perekonya-bérc; Bükkmogyorósd: Csepegő-bérc; Hevesaranyos: Köszörűs; 
Szúcs: Csehi-bérc; Uhg: Borsodbóta: Tó-padja; Dédestapolcsány: Bárci-tető, Kukorica-föld; Sajómercse: Ágazat-völgy, Finta-tető, Mercse-ágazat; Uppony: Dedevár; Tv: Borsodnádasd: Karácsonylova, Kerek-berek-fö, Pap-lápa; Kissikátor: Renget-verő; Ózd: Körtvészer-tető; Óm: Borsodnádasd: Sülye-völgyi-bérc; Ózd: Szilas-tető; Pm: Fedémes: Alsó-sóska-hely; Hevesaranyos: Kis-verő (SI); Váraszó: Barca Tamás (BÁ); Uh: Arló: Szohony; Borsodbóta: Őrhegy (SJ); Borsodnádasd: Mesgye-hegy (BÁ); Csernely: Borjúmáj, Kerek-völgy-tető (SI); Csokvaomány: Nemecke-árnyék (BÁ); Királd: Mazsúr, Őr-tető, Őzvény-oldal; Sajómercse: Gógány, Körtvélyes, Nagy-hegy, Nyúzó-völgy, Szarvaskút (SJ); Sajónémeti: Rátos (BÁ). CEU: [7787.3], [7787.4], [7788.1], [7788.3], [7788.4], [7886.2], [7887.2], [7887.3], [7887.4], [7888.1], [7888.2], [7888.3], [7986.2], [7987.1], [7987.2], [7987.3], [7987.4], [8087.2].

1524,1. Prunella $\times$ dissecta Wender. - Mindkét lelőhelyen egyetlen példány szülőfajok társaságában. Uh: Arló: Szohony; Borsodbóta: Őr-hegy (SJ). CEU: [7788.3], [7887.2].

1528. Calamintha menthifolia Host - Cseres és gyertyános-tölgyesekben, ritkábban bükkösökben szórványos. Uhg: Dédestapolcsány: Derennek-völgy, Éles-kő, Lipóc, Rádincs-völgy, Sár-oldal; Nekézseny: Fehér-kő; Uppony: Zsellér-földek; Tv: Arló: Elő-Poporó, Kis-Poporó, Közép-Poporó, Remete-bérc; Domaháza: Nyárjasság (SJ); Pétervására: Szénégető-völgy (BÁ); Váraszó: Fenekes, Szénégető-hegyese (SJ); Zabar: Verő-mocsolya (BÁ). CEU: [7788.4], [7886.1], [7886.2], [7886.3], [7886.4], [7887.1], [7887.3], [7888.2], [7986.3].

1557. Salvia glutinosa L. - Üdébb lomberdőkben gyakori. Bh: Tarnalelesz: Bihaj-ortás; Tv: Domaháza: Magas-verő; Pm: Tarnalelesz: Babar-völgy (BÁ). CEU: [7886.2], [7987.1], [7987.3].

1560. Salvia austriaca Jacq. - Száraz gyepekben, sztyepréteken. Bh: Hevesaranyos: Sashegy; Uhg: Dédestapolcsány: Kerek-domb, Nagy-hegy-alja (SJ); Tv: Tarnalelesz: Hencortvány; Pm: Erdőkövesd: Öv-hegy (BÁ); Fedémes: Víg István-tető (SJ); Váraszó: Öv-hegy; Uh: Csokvaomány: Vén-szőlő (BÁ). CEU: [7888.1], [7888.2], [7986.2], [7986.4], [7987.1], [7987.3].

1572. Physalis alkekengi L. - Akácelegyes degradált erdőkben, gyertyános-tölgyesekben, bükkösökben. Bh: Tarnalelesz: Bihaj-ortás (BÂ); Uhg: Dédestapolcsány: Lipóc; Nekézseny: Fehér-kő; Uppony: Vízköz (SJ); Tv: Váraszó: Epres-lápa; Pm: Erdőkövesd: Kis-völgy-far; Tarnalelesz: Babar-tető (BÁ). CEU: [7788.4], [7888.2], [7986.2], [7987.1], [7987.3].

1581. Solanum villosum Mill. s. str. - Még egy ismert aktuális adata van az Északiközéphegységből, Abod határából (Cserehát), hasonló jellegű élőhelyről, lomberdő zavartabb részéből [1] (VIRóK et al. 2004). Új a Tarnavidékre. Tv: Arló: Gyöngy-ág-bérc - $\underline{\text { Herb.: }}$ 2011.8.27. - bükkösben vezető erdőgazdasági út mentén ritka (BÁ). CEU: [7886.4].

1605. Scrophularia vernalis L. - Patakmenti égerligetekben és üde bükkösökben ritka. Tv: Tarnalelesz: Pataj-völgy, Szék-fő-völgy, Vízválasztó; Váraszó: Váraszói-völgy; Uh: Sajóvelezd: Vár-erdő (BÁ). CEU: [7788.2], [7886.4].

1631. Veronica beccabunga L. - Tv: Váraszó: Molnár-lápa - kis vízfolyásban (SJ). CEU: [7886.4].

1637. Veronica teucrium L. - Erdőssztyepréten kb. félszáz töve. Uhg: Dédestapolcsány: Nagy-hegy - Herb.: 2008.6.2. (BÁ). CEU: [7888.2].

1646. Veronica dillenii Crantz - Uh: Arló: Benéte - Herb.: 2008.6.2. - kavicsos talajon, nyílt gyepben, ritka (BÁ). CEU: [7887.2].

1670. Odontites lutea (L.) Clairv. - Szálkaperjés gyepek és sztyeprétek növénye. Bh: Borsodnádasd: Láz; Tv: Borsodnádasd: Hasznos, Karácsony-hegy, Karácsonylova, Kerek-berekfő; Tarnalelesz: Henc-ortvány; Óm: Borsodnádasd: Karácsonylova-völgy; Uh: Borsodbóta: Csépány-tető (BÁ). CEU: [7788.3], [7887.3], [7887.4], [7987.1], [7987.2].

1682. Globularia punctata Lapeyr. - Elsősorban borókás nyíltabb gyepek növénye, de üdébb homokkő-sziklagyepekben és egyéb nyíltabb gyepekben is előfordul. A Pétervásári-medencében nem ritka. Bh: Hevesaranyos: Veres-hegy (SJ); Tv: Bükkszenterzsébet: Dobogó-bérc; Is- 
tenmezeje: Nagy-Musák (BÁ); Váraszó: Kő-orom (SJ); Pm: Bükkszenterzsébet: Szőlő-megihegy; Erdőkövesd: Kis-völgy-far, Öv-hegy (BÁ); Fedémes: Árpaszó-hegy, Kútos-tető (SI); Tarnalelesz: Mocsolyás, Pap-völgy néven BERÁNeK (2007) (BÁ), Tormás-hegy (SJ); Váraszó: Békalyuk-orom, Gödrösi, Hereg-vár, Ó-hegy - Herb.: 2008.5.16., Patakverej, Szőlő-megi-hegy, Szőlő-megi-oldal, Vagdaszó-bérc (BÁ). CEU: [7986.2], [7986.4], [7987.1], [7987.3].

1687. Orobanche purpurea Jacq. - Tv: Arló: Elö-Poporó - cseres-tölgyesben, Achillea distanson (SJ). CEU: [7887.3].

1688. Orobanche arenaria Borkh. - Az Északi-középhegységben ritka fajnak a legközelebbi előfordulása a Medvesről (CSIKY 2004) és a Putnoki-dombságból ismert (Bátori Gábor 2005 [1]). Az Upponyi-hegységre és a Tarnavidékre új. Uhg: Nagybarca: Kurittyán-tető, Szelestető - mindkét lelőhelyen sztyepréten, Artemisia campestrisen (SJ); Tv: Pétervására: Lyukas-kő - homokkő-sziklagyepben ritka (BÁ). CEU: [7789.1], [7986.3].

1694. Orobanche alba Stephan ex Willd. - Száraz gyepekben, sztyepréteken szórványos. Bh: Szilvásvárad: Salamon-vár; Tv: Váraszó: Kő-orom; Óm: Borsodnádasd: Szalinca; Uh: Csernely: Ecetes-Tök, Nemecke, Nyékes-tető, Pete-fia; Járdánháza: Szalinca; Sajómercse: Adár-bérc, Kerek-rét, Szarvaskút (SJ). CEU: [7788.3], [7887.2], [7887.4], [7888.1], [7888.3], [7986.2].

1703. Orobanche lutea Baumg. - Félszáraz gyepekben és sztyepréteken. Uhg: Dédestapolcsány: Hosszú-berek-tető; Nagybarca: Kurittyán; Sajóvelezd: Bába-szék, Magas-hegy (SI);

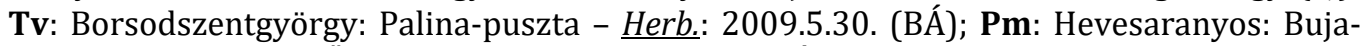
hegy (SJ); Uh: Sáta: Ốr-hegy - $\underline{\text { Herb.: }}$ 2009.5.13. (BÁ). CEU: [7788.2], [7788.3], [7789.1], [7886.2], [7888.2], [7986.4].

1704. Orobanche bartlingii Griseb. - Köves talajú száraz és félszáraz gyepekben, cserjésekben, Libanotison. Lokálisan nem ritka. A növény első adata az Upponyi-hegységből Beránek Ábeltől származik, aki 2008-ban találja meg a dédestapolcsányi Nagy-hegyen (MoLNÁR et al. 2019). Legközelebb a Rudabányai-hegységben fordul elő (VIRóK et al. 2004). Uhg: Dédestapolcsány: Balta-tető (SJ). CEU: [7888.2].

1705. Orobanche flava Mart. ex F.W. Schultz. - Óm: Borsodnádasd: a település belterületén a 2009-ben publikált „Bánya-felett” lelőhelytől nem messze is előkerült 2009.8.16-án (BERÁNEK 2009), így a növény a 7887.4 és a 7987.2 kvadrátokban is előfordul. (BÁ). CEU: [7887.4].

1729. Galium palustre L. - Tv: Arló: Zár-rét - Herb.: 2017.6.22. - sásos égerligetben (BÁ). CEU: [7887.1].

1751. Plantago indica L. - Legeltetett nyíltabb száraz gyepekben ritka. Kajtásza területéről BENEDEK \& ZAY (1987), a Pétervásárai-medence számos pontjáról LENGYEL (1906), míg Ózd mellől BuDAI (1914) említi korábbi adatait. Vojtkó András már jelzi a fajt 2004-ben a flóratérképezési program során a 7986.2-es kvadrátból, Váraszó helynévvel [1]. Pm: Bükkszenterzsébet: Kajtásza - BENEDEK \& ZAY (1987) adatának megerősítése, Parasztagi-völgy Herb.: 2009.8.22. (BÁ). CEU: [7986.2].

1764. Viburnum opulus L. - Égerligetek és ritkábban egyéb vegyes lomberdők növénye. Bh: Bükkmogyorósd: Csepegő-forrás (SJ); Uhg: Dédestapolcsány: Balta-tető, Makkos-alja, Nagyhegyi-szőlő, Nagy-hegy-orom; Nekézseny: Avas-bérc (BÁ); Uppony: Vízköz (SJ); Tv: Borsodszentgyörgy: Palina-völgy, Teresznek-völgy; Istenmezeje: Hagymás-eleje - Herb.: 2011.9.11, Hosszú-orom; Hangony: Renget-völgy; Ózd: Harmaci-völgy-fó - Herb.: 2009.5.10. (BÁ); Sajópüspöki: Szurdok (SJ); Váraszó: Hosszú-ág-lápa, Váraszói-völgy; Uh: Borsodnádasd: Budaberki-völgy (BÁ). CEU: [7786.4], [7787.1], [7788.1], [7788.4], [7886.2], [7886.4], [7887.1], [7887.4], [7888.2], [7888.3], [7986.1].

1765. Viburnum Iantana L. - Meleg, száraz tölgyesekben, szegélycserjésekben. Uhg: Dédestapolcsány: Halabuka-tető; Nekézseny: Avas-bérc, Upponyi-tető; Uppony: Cibróka (BÁ). CEU: [7788.4], [7888.2]. 
1773. Adoxa moschatellina L. - Uhg: Uppony: Eszkála-tető - hárs-kőris sziklaerdőkben; Tv: Hangony: Hangonyi-Renget-völgy - égerligetben, Vizes-völgy-fő - gyertyános-tölgyesben lévő homokkőkibúváson és környékén. (SJ). A növény az Upponyi-hegységből volt eddig ismert, ahol Budai József 1912. 5. 5-én gyüjtötte az Upponyi-szorosban (BUDAI ap. Soó 1943). Adatát Beránek Ábel erősíti meg (BERÁNEK 2007). A Tarnavidékről eddig nem került elő. CEU: [7786.4], [7788.4].

1782. Valeriana dioica L. - Üde láprétek, magassásosok és kakukktormás égerligetek növénye. Tv: Arló: Gyepes-völgy (SJ); Borsodszentgyörgy: Kántor-lápa, Kémének-völgy (BÁ), Pa-

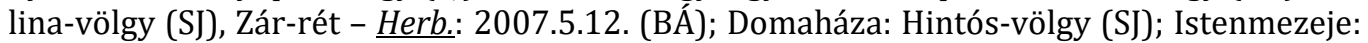

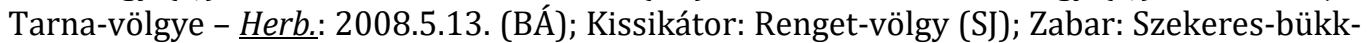
völgy (BÁ). CEU: [7886.1], [7886.2], [7886.3], [7887.1].

1784. Cephalaria transsylvanica (L.) Schrad. - Száraz gyepekben. Pétervására mellett Vrabélyi Márton gyűjti elsőként (1865.7.3. - EGR), majd Lengyel Géza is Pétervására (1904.8. - BP-321504), majd Istenmezeje (1904.8. - BP-321501) környékéről említi (VRABÉLYI 1868, LENGYEL 1906). Vojtkó András már jelzi a fajt 2004-ben a flóratérképezési program során a 7986.4-es kvadrátból, Pétervására helynévvel [1]. Pm: Erdőkövesd: Új-

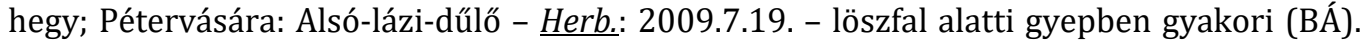
CEU: [7986.4].

1785. Dipsacus pilosus L. - Völgytalpi égerligetekben, gyertyános-tölgyesekben. Uhg: Dédestapolcsány: Rádincs-völgy; Nekézseny: Csernely-patak-völgye; Tv: Arló: Vizes-lápabérc; Borsodszentgyörgy: Palina-völgy (SJ); Erdőkövesd: Köves-völgy (BÁ); Kissikátor: Renget-völgy (SJ); Váraszó: Kis-dél (SA), Köves-út (BÁ), Molnár-lápa (SJ), Nagy-Ves-völgy (BÁ). CEU: [7886.2], [7886.4], [7887.1], [7888.2], [7986.1], [7986.2].

1788. Succisa pratensis Moench - Uhg: Bánhorváti: Nagy-oldal, Molinia arundinaceas szálkaperjés gyepben 3 egyed, Gentiana pneumonantheval együtt (SJ). CEU: [7788.4].

1793. Scabiosa canescens Waldst. et Kit. - Nyíltabb homokkőtörmelékes gyepek, nyílt talajú borókások és sztyeprétek növénye. Tv: Szentdomonkos: Kő-hegy (SJ); Váraszó: Kő-orom, Tó-hegyese (BÁ); Pm: Bükkszenterzsébet: Buk-násza (SJ), Lő-láz; Erdőkövesd: Öv-hegy -

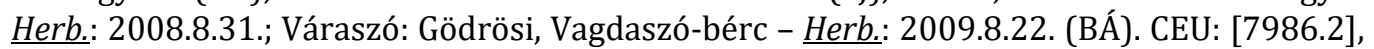
[7986.4], [7987.1].

1797. Campanula glomerata L. - Sztyepréteken. Uhg: Bánhorváti: Varbó-oldal; Dédestapolcsány: Nagy-hegy; Uh: Borsodbóta: Szőlő-oldal, a Vas-tető déli oldala - Herb.:

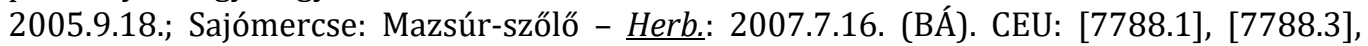
[7788.4], [7888.2].

1799. Campanula cervicaria L. - Elsősorban mészkerülő gyepekben, valamint cserestölgyesben (Pétervására). Tv: Domaháza: Csúnya-fő (BÁ), Hajagos (SJ), Kerek-Bükk, KisSzegeggye-tető, Máté-Bükk, Mihály-homloka, Nagy-Szegeggye, Répás-tető - $\underline{\text { Herb.: }}$ 2009.7.4., Szekeres-Bükk, Szilvás-árnyéka; Istenmezeje: Alsó-Hagymás-bérc; Pétervására: Külső-hang-láza (BÁ). CEU: [7886.1], [7886.2], [7986.1].

1801. Campanula bononiensis L. - Uh: Csernely: Alsó-Nyékes - sztyepréten (SJ). CEU: [7888.1].

1813. Asyneuma canescens (Waldst. et Kit.) Griseb. et Schenk - Melegkedvelő tölgyesekben, bokorerdőkben, tölgyes sziklaerdőkben, sziklagyepekben, sztyepréteken. Budai József 1912.5.5-én gyűjti először az Upponyi-szorosban. Uhg: Uppony: Dedevár, Fekete-kő-tető, Kalica-tető, Upponyi-szoros - $\underline{\text { Herb. }}$ : 1912.5.5. (BP-164748), 1960.8.18 (BP-401747), Budai József és Boros Ádám adatának megerősítése (Boros 1960) (SJ). CEU: [7788.4].

1816. Jasione montana L. - Némileg üdébb, nyíltabb mészkerülő gyepekben ritka. Tv: Domaháza: Répás-tető; Zabar: Ments-árnyék - Herb.: 2008.10.5. (BÁ). CEU: [7886.1].

1823. Solidago gigantea Aiton - Degradált üde gyepekben, égerligetek szegélyében. Uhg: Dédestapolcsány: Veszett-szög; Uh: Csernely: Nagy-Horsó-völgy, Szohony-fó (SJ). CEU: [7887.2], [7887.4], [7888.2]. 
1824. Solidago canadensis L. - Vágásterületeken, utak mentén, erdőszegélyekben és szinte minden gyeptípusban tömegesen előfordul. Erősen terjedőben! Bh: Bükkmogyorósd: Alsósűrű-bérc - a Salamon-vár északnyugati gerincétől északra lévő 346,5 és 345,2 m-es dombok; Uhg: Bánhorváti: Bán-völgye, Bárci-oldal, Hosszú-berek, Nagy-rét; Csokvaomány: Csernely-patak-mente; Dédestapolcsány: Bárci-tető, Halabuka-tető, Kerek-domb, Lázbércivíztároló, Varjas-szőlő, Veszett-szög; Sáta: Csernely-patak-völgye; Uppony: Csernely-patakvölgye, Vízköz, Vízköz-szoros; Tv: Arló: Gyepes-völgy; Istenmezeje: Tamás telke-völgy; Pm: Bükkszék: Leleszi-szállás; Fedémes: Meggyes-lápa; Tarnalelesz: Bolya-puszta; Uh: Arló: Arlói-tó, Macó-bérc; Csernely: Lukács Gergelyesse, Szohony-fő; Csokvaomány: Alsó-rét, Felsőrét - a Hosszú-dűlőtől délre eső rét a Csernely-pataktól nyugatra, Hosszú-dűlő, Liba-tető, Nemecke-árnyék, Vasút-tető (SJ). CEU: [7788.4], [7886.3], [7887.1], [7887.2], [7887.4], [7888.1], [7888.2], [7888.3], [7986.4], [7987.3].

1828. Aster linosyris (L.) Bernh. - Sztyepréteken, erdőssztyepréteken. Bh: Csernely: Cserjetető; Hevesaranyos: Gyilkos-tető; Szilvásvárad: Salamon-vár; Uhg: Bánhorváti: Lapác, Nagy-hegy, Nagy-oldal, TSZ-legelő; Dédestapolcsány: Kerek-domb, Köszörűs és varjas, Kukorica-föld, Nagy-hegy, Varjas-szőlő; Uppony: Cibróka, Csipeles-domb; Óm: Borsodnádasd: Szalinca (SJ); Ózd: Borbás-hegy; Pm: Erdőkövesd: Öv-hegy (BÁ); Hevesaranyos: Kis-verő (SJ); Váraszó: Hereg-vár, Títás (BÁ); Uh: Csokvaomány: Babos (SJ), Farkas-tető (BÁ), Libatető; Sajómercse: Gógány, Szörnyü-völgy (SJ). CEU: [7787.4], [7788.3], [7788.4], [7789.3], [7887.4], [7888.1], [7888.2], [7888.3], [7986.2], [7986.4], [7987.3].

1831. Aster amellus L. - Erodált száraz gyepekben, szálkaperjés réteken, erdőszegélyekben, melegkedvelő tölgyesekben. A térségből elsőként Budai József gyűjti Dédestapolcsány mellől közelebbi helymegjelölés nélkül (1906.9.17. - BP-166057). Bh: Bátor: Megyaszó-fő; Bekölce: Perekonya-bérc (SJ); Borsodnádasd: Láz (BÁ); Bükkmogyorósd: Alsó-sűrű-lápa, Csepegő-bérc; Hevesaranyos: Gyilkos-tető, Ürge-hegy, Ürge-lápa; Uhg: Bánhorváti: Máli-oldal, Nagy-rét (SJ), Varbó-oldal (BÁ); Borsodbóta: Menyhárt, Tó-padja; Dédestapolcsány: Baltatető, Éles-kő, Halabuka-tető, Kerek-domb, Mocsolya, Nagy-hegy-alja, Nagy-hegyi-szőlő, Nagy-hegy-orom, Sár-oldal, Varjas-szőlő; Nekézseny: Nagy-mál-tető; Sáta: Hosszak és Kéritó, Kotyindó-tető; Uppony: Fekete-kő-tető, Kalica-tető; Tv: Borsodnádasd: Hasznos, Karácsonylova, Kerek-berek-fő, Óm: Borsodnádasd: Láz-tető - a Láz-oldal fölötti 309,8 m-es hegy, Sülye-völgyi-bérc (SJ); Ózd: Borbás-hegy (BÁ), Szilas-alja-hegyese, Szilas-tető; Pm: Fedémes: Víg István-tető; Szentdomonkos: Tormás-hegy; Tarnalelesz: Kastály-legelő, Tormás-hegy (SJ); Uh: Borsodbóta: Csépány-tető (BÁ), Régi-tábla (SJ); Borsodnádasd: Balatoni-tető (BÁ); Csernely: Borjúmáj, Lukács Gergelyesse, Nagy-Horsó-tető (SJ); Csokvaomány: Andornak, Szilfás, Vén-szőlő (BÁ); Járdánháza: Szalinca; Sajómercse: Körtvélyes, Nagyhegy, Nyúzó-völgy, Őr-hegy (SJ); Sajónémeti: Rátos; Sáta: Belterület, Bükkfő, Csépányberek, Kós-ortvány (BÁ). CEU: [7787.3], [7787.4], [7788.1], [7788.3], [7788.4], [7887.2], [7887.3], [7887.4], [7888.1], [7888.2], [7888.3], [7986.4], [7987.1], [7987.2], [7987.3], [8087.1].

1846. Gnaphalium sylvaticum L. - Mészkerülő erdőszélek és ritkábban mészkerülő gyepek növénye. Bh: Bekölce: Róna-bérc; Borsodnádasd: Bánya-fölött; Tv: Borsodszentgyörgy: Kígyós-hegy - Herb.: 2004.10.3.; Domaháza: Kis-Szegeggye-tető, Szekeres-Bükk, Utas-árnyék (BÁ); Váraszó: Csókás-völgy (SJ); Uh: Borsodnádasd: Csiterkötő; Csokvaomány: Kaizsárnyék-fark, Kis-Omány-oldal, Nyékes-tető (BÁ). CEU: [7886.1], [7886.2], [7886.4], [7887.1], [7887.4], [7888.1], [7987.2].

1853. Inula hirta L. - Szálkaperjés gyepekben, erdőssztyepréteken, sztyepréteken, erdőszegélyekben, melegkedvelő tölgyesekben. Bh: Bükkmogyorósd: Salamon-vár; Csernely: Cserje-tető; Szilvásvárad: Salamon-vár; Uhg: Dédestapolcsány: Balta-tető, Éles-kő-tető, Halabuka-tető, Hosszú-berek-tető, Kerek-domb, Köszörűs és varjas, Nagy-hegy, Sár-bérc, Varjasszőlő; Nekézseny: Nagy-mál-tető; Uppony: Dedevár, Három-kő; Óm: Borsodnádasd: Szalin- 
ca; Pm: Hevesaranyos: Kis-Ecser; Tarnalelesz: Lóhát-orom; Uh: Arló: Pocsi-bérc; Járdánháza: Szalinca (SJ). CEU: [7788.4], [7887.2], [7887.3], [7887.4], [7888.1], [7888.2], [7888.3], [7986.4], [7987.3].

1856. Inula germanica L. - Erdőssztyep-erdőben és gyepekben. A Bükk és a Mátra előterében szórványos előfordulású növénynek a dombvidékről eddig nem volt adata. Bh: Egercsehi: Nagy-oldal; Óm: Borsodnádasd: Szalinca; Uh: Járdánháza: Szalinca (SJ). CEU: [7887.4], [7987.2].

1901. Achillea distans Waldst. et Kit. ex Willd. - Cseres-tölgyesben szórványos. Tv: Pétervására: Külső-hang-láza - Herb.: 2008.6.15. (BÁ). CEU: [7986.1].

1905. Achillea pannonica Scheele - Idősebb molyhos tölgyesben. Tv: Tarnalelesz: Vermeshát - Herb.: 2017.6.27. (BÁ). CEU: [7887.3].

1929. Artemisia pontica L. - Sztyepréteken, erdőssztyepréteken, felnyíló tölgyesekben. Uhg: Bánhorváti: Lapác (SA), Nagy-hegy, Nagy-oldal; Dédestapolcsány: Köszörűs és varjas, Kukorica-föld (SJ); Uppony: Három-kő; Óm: Ózd: Szilas-alja-hegyese, BERÁNEK (2007) Sziltető adata ide vonatkozik; Pm: Hevesaranyos: Kis-Ecser (SI); Tarnalelesz: Babar-tető Herb.: 2008.8.30. (BÁ); Uh: Csokvaomány: Felső-rét, Liba-tető (SI), Vén-szőlő (BÁ). CEU: [7787.3], [7788.4], [7888.1], [7888.2], [7987.1], [7987.3].

1932. Petasites albus (L.) Gaertn. - Bükkösökben, szurdokerdőkben, patakmenti égeresekben. Tipikus útrézsűkben és meredek, suvadásos oldalakon. A kb. 10-15 éve levágott bükkösök helyén a tarnaleleszi Futyóköz-orma és Pataji-far területén több ezres tömegben jelent meg. Tv: Arló: Lencsényi-tető, Nagy-hát-Sertés, Szedres-ág-bérc (SJ); Istenmezeje: Alsó-Szerpatak-gödre, Csengős-fő, Csernyus, Felső-Kajra-völgy, Hagymás-völgy - Herb.: 2007.4.30., Hegyes-kukucsa, Nagy-Csengős, Nagy-Rákos-laposa, Rákos-völgy (BÁ); Járdán-

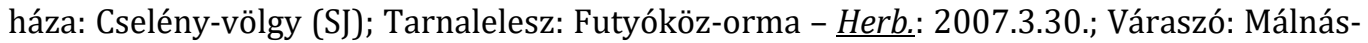
bérc, Patak-fó (BÁ). CEU: [7886.4], [7887.1], [7887.3], [7985.2], [7986.1].

1933. Petasites hybridus (L.) G. Gaertn., B. Mey. et Scherb. - Égerligetekben, erdőszéli és patakparti magaskórósokban. Uhg: Dédestapolcsány: Éger-alja (BÁ), Veszett-szög (SJ); Nekézseny: Bánya-oldal (BÁ), Csernely-patak-völgye (SI), Suta-völgy (BÁ); Sáta: Csernelypatak-völgye (SI); Tv: Hangony: Hangonyi-Renget-völgy, Nagy-Golotka-völgy; Váraszó: Hosszú-ág-lápa (BÁ). CEU: [7786.4], [7788.4], [7886.2], [7886.4], [7888.2].

1938. Erechtites hieracifolia (L.) Raf. ex DC. - Bükkösök vágásain és erdészeti utak mentén, fényben gazdagabb üde erdőkben. Uhg: Dédestapolcsány: Halabuka-tető (SJ); Tv: Arló: Futyó-nagy-verő, Gyöngy-ág-völgy (BÁ); Istenmezeje: Völgy-árnyék-bérc; Váraszó: Kenyér-

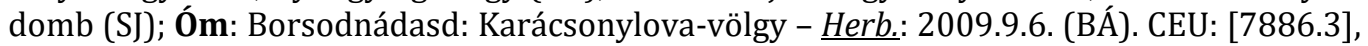
[7886.4], [7887.3], [7888.2].

1941. Tephroseris integrifolia (L.) Holub - Félszáraz gyepekben, erdőszegélyben, nyúlfarkfüves sziklagyepben, üde szegélynövényzetben. Uhg: Uppony: Eszkála-tető, Kalica-tető, Upponyi-szoros - Herb.: 2009.5.13. (BÁ). CEU: [7788.4].

1955. Senecio germanicus Wallr. - Üde lomberdőkben. Bh: Borsodnádasd: Bató-dúlő Herb.: 2009.8.16. (BÁ); Uhg: Dédestapolcsány: Lipóc; Uppony: Bender-oldal, Lázbérci-

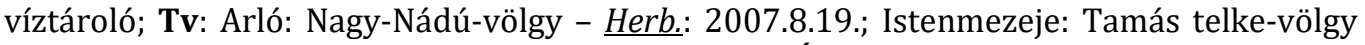
(SJ); Váraszó: Nagy-Ves-völgy - Herb.: 2007.8.18. (BÁ). CEU: [7788.4], [7886.3], [7887.3], [7888.2], [7987.2].

1957. Senecio doria Nath. - Az elsősorban alföldi elterjedésű növénynek ez az első adata a dombvidékről. A legközelebbi előfordulása a Bükkben Noszvaj határában található (Schmotzer András 2017 [1]). Bh: Borsodnádasd: Láz - Herb.: 2009.8.16. - üde gyepben szórványos (BÁ). CEU: [7987.2].

1961. Carlina acaulis L. - Első adatát VojTKó (2008) közli a Tarnavidékről. Az Upponyihegységre új. Uhg: Borsodbóta: Kotyindó-tető, szálkaperjés gyepben 41 tő (SJ); Tv: Domaháza: Répás-tető. Mészkerülő, faelegyes, siska nádtippan alkotta gyepben kb. 40 tő; Pm: 
Bükkszenterzsébet: Róna, meszes legelőn egyetlen töve. (BÁ). CEU: [7788.3], [7886.1], [7986.2].

1963. Xeranthemum cylindraceum Sibth. et Sm. - Száraz gyepekben és kökényesek szélein. Bh: Balaton: Nagy-völgy; Bekölce: Cseres-bérc, Cserje-hegy - Herb.: 2008.7.12.; Borsodnádasd: Cseres-bérc; Tv: Bükkszenterzsébet: Nagy-kő; Pm: Bükkszenterzsébet: Kilincs; Uh: Borsodnádasd: Csiterkötő (BÁ); Sajómercse: Szarvaskút (SJ). CEU: [7788.3], [7887.4], [7986.2], [7987.2].

1975. Carduus crispus L. - Füzes ligeterdők mentén és magaskórósokban szórványos. Uhg: Dédestapolcsány: Lázbérci-víztároló, Rigós-lápa; Uppony: Alsó-völgy - Herb.: 2008.8.10.; Tv: Ózd: Kajla-völgy - Herb.: 2007.7.29.; Váraszó: Hosszú-völgy - Herb.: 2007.8.18., Kövesút, Szénégető-hegyese; Óm: Borsodnádasd: a Hódos-patak belterületi szakaszán, a lemezgyár alatt (BÁ). CEU: [7787.4], [7788.4], [7886.4], [7887.4], [7888.2], [7986.2].

1978. Carduus collinus Waldst. et Kit. - Melegkedvelő tölgyesekben, homokkő-

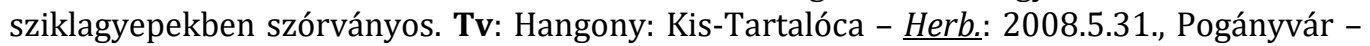
Herb.: 2009.5.27.; Istenmezeje: Noé szőlője - $\underline{\text { Herb.: }}$ 2017.6.25., Száraz-ág; Pétervására: Lyukas-kő - Herb.: 2009.7.19. (BÁ); Szentdomonkos: Nagy-Ormos-hegy (SJ); Tarnalelesz: Vermes-hát (BÁ); Uhg: Uppony: - Herb.: 1910.6.6. (BP-178007), Budai közelebbi helymegjelölés nélkül gyűjtötte. CEU: [7786.4], [7787.3], [7887.3], [7986.1], [7986.3], [7987.1].

1985. Cirsium palustre (L.) Scop. - Tv: Domaháza: Miklós-fája - üde réten kis populációja, amelynek egyedszáma 1-3 egyed között változik (BÁ), Nagy-völgy - lápréten 4 egyed (SJ). CEU: [7886.2].

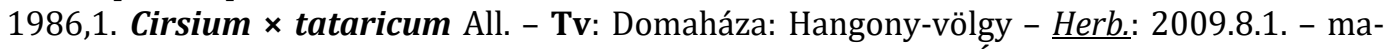
gaskórósban a nagy tömegben jelenlévő szülőfajok közt ritka (BÁ). CEU: [7886.2].

1987. Cirsium pannonicum (L. f.) Link - Szálkaperjegyepekben szórványos. Bh: Hevesaranyos: Köszörűs; Uhg: Borsodbóta: Menyhárt, Tó-padja; Dédestapolcsány: Éles-kő-tető (SJ), Halabuka-tető, Nagy-hegyi-szőlő (BÁ); Sáta: Kotyindó-tető (SJ); Óm: Ózd: Szállás-tető, Miklós utca néven (BERÁNEK 2008) (BÁ); Uh: Borsodbóta: Őr-hegy; Sajómercse: Szörnyű-völgy (SJ). CEU: [7787.4], [7788.3], [7888.1], [7888.2], [8087.2].

1989. Cirsium oleraceum (L.) Scop. - Égerligetekben, magaskórósokban, mocsárréteken. Bh: Bükkmogyorósd: Alsó-sűrű-lápa, Csepegő-forrás; Szilvásvárad: Egres-völgy (SJ); Uhg: Bánhorváti: Éles-kő-tető (BÁ); Borsodbóta: Sáros-út; Dédestapolcsány: Éger-alja; Sáta: Csernely-patak-völgye; Tv: Arló: Dobronya-tető - a Dobronya-fó délkeleti 391,1 m-es gerince, Körtvélyes, Zár-rét, Zsá-völgy; Borsodszentgyörgy: Kalitka-völgy, Palina-völgy; Cered: Vörös-csáté-völgy; Domaháza: Asztag-völgy, Felső-völgy, Hangony-völgy (SJ), Miklósfája (BÁ), Nagy-völgy, Örvényes-völgy - a Nagy-völgy első nyugati oldalvölgye a SzélesImola-völggyel szemben, Répás-völgy (SJ), Son-torok, Sózó-völgy (BÁ), Tó-völgye-patak; Istenmezeje: Tarna-völgye; Járdánháza: Cselény-völgy; Kissikátor: Renget-völgy (SI); Szentdomonkos: Hajagos-völgy (BÁ); Zabar: Zabar-völgy; Óm: Arló: Szentgyörgyi-patakvölgye (SJ); Borsodnádasd: Karácsonylova-völgy (BÁ); Uh: Arló: Bagó-lápa, Csahó-völgy, Izra-völgy (SJ). CEU: [7788.3], [7788.4], [7886.1], [7886.2], [7886.3], [7887.1], [7887.2], [7887.3], [7887.4], [7888.2], [7888.3], [7986.1], [7987.1].

1993. Serratula tinctoria L. - Üdébb gyepben szórványos. Uh: Csokvaomány: Alsó-pást, Hosszú-dűlő (BÁ). CEU: [7888.1].

1999,5. Centaurea jacea L. s. l. subsp. macroptilon (Borbás) Hayek - Bh: Lénárddaróc: Alsó-hosszas - sásos mocsárréten (SJ). CEU: [7888.3].

2000. Centaurea indurata Janka - Mezofil tölgyesek szegélyében, szálkaperjés réteken. Tv: Borsodszentgyörgy: Vadberke; Domaháza: Hintós-völgy, Répás-verő (SJ); Tarnalelesz: Kaszáló-fő - Herb.: 2002.8.1. (BÁ); Óm: Ózd: Szilas-tető; Uh: Csernely: Kakarcsó; Sajómercse: Körtvélyes (SJ). CEU: [7787.3], [7788.3], [7886.1], [7886.2], [7886.4], [7887.1], [7888.3]. 
2002. Centaurea stenolepis A. Kern. - Mocsárréteken, félszáraz gyepekben. Uhg: Sáta: Pipis-hegy (SJ); Óm: Ózd: Nagy-fák-alja - Herb.: 2004.7.16., Vizslás - Herb.: 2004.7.7. (BÁ). CEU: [7787.4], [7888.1].

2003. Centaurea cyanus L. - Kalászos vetések szélén szálanként. Bh: Balaton: Nagy-völgy; Tv: Hangony: Hangony-völgy; Pm: Pétervására: Alsó-lázi-dűlő (BÁ). CEU: [7787.3], [7887.4], [7986.4].

2005,2. Centaurea triumfettii All. subsp. stricta (Waldst. et Kit.) Dostál - Sztyepréteken, erdőssztyepréteken, félszáraz gyepekben, erdőszegélyekben. Uhg: Borsodbóta: Menyhárt;

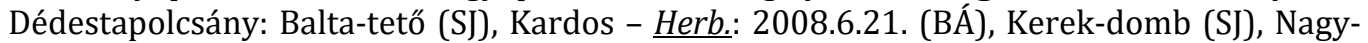
hegy - Herb.: 2008.6.2. (BÁ), Sár-bérc (SJ); Nekézseny: Avas-bérc - Herb.: 2008.6.21. (BÁ), Nagy-mál-tető (SJ); Uh: Borsodbóta: Őr-hegy; Sajómercse: Körtvélyes (SJ); Sáta: Őr-hegy Herb.: 2008.6.2. (BÁ). CEU: [7788.3], [7888.1], [7888.2].

2008,1. Centaurea scabiosa L. s. l. subsp. sadleriana (Janka) Asch. et Graebn. - Löszöshomokos talajú sztyepréteken, szálkaperjés gyepekben. Átmeneti alakok is a C. scabiosa felé. Bh: Hevesaranyos: Gyilkos-tető, Ürge-hegy, Veres-hegy; Pm: Hevesaranyos: Buja-hegy, Víg István-tető; Tarnalelesz: Fingászó-hegy-orma, Kastály-legelő (SJ). CEU: [7986.4], [7987.3].

2016. Hypochoeris maculata L. - Sztyepréteken. Bh: Bükkmogyorósd: Salamon-vár; Uhg: Bánhorváti: Bárci-tető, Máli-oldal; Borsodbóta: Vatos, Veres-domb; Dédestapolcsány: Bárci-tető, Halabuka-tető, Hosszú-berek-tető, Kerek-domb, Köszörűs és varjas, Nagy-hegy, Varjas-szőlő (SJ); Nekézseny: Avas-bérc (BÁ), Nagy-mál-tető (SJ), Sordé-tető; Uppony: Cibróka (BÁ), Három-kő (SJ); Tv: Domaháza: Mihály-tető (BÁ); Hangony: Kis-berek-bérc; Óm: Borsodnádasd: Szalinca; Pm: Fedémes: Alsó-sóska-hely, Kútos-tető; Tarnalelesz: Lóhát-orom; Uh: Arló: Izra, a Konnya- és Izra-völgy közötti 347,1 m-es hegy (SJ); Borsodnádasd: Mesgye-hegy, Mocsolyás-tető (BÁ), Mocsolyás-völgy; Csernely: Kerek-völgy-tető, Lukács Gergelyesse, Nemecke; Csokvaomány: Babos, Pap-hegyese, Páter-oldal; Járdánháza: Szalinca; Sajómercse: Szörnyű-völgy; Sajóvelezd: Lapos-kő (SJ). CEU: [7786.4], [7788.2], [7788.3], [7788.4], [7886.2], [7887.2], [7887.4], [7888.1], [7888.2], [7888.3], [7986.4], [7987.3].

2026. Scorzonera purpurea L. - Meszes sztyeprétek ritkább növénye. Tv: Tarnalelesz: Henc-ortvány - $\underline{\text { Herb.: }}$ 2008.5.16. (BÁ); Óm: Borsodnádasd: Szalinca (SJ); Pm: Erdőkövesd: Öv-hegy - Herb.: 2008.5.13. (BÁ); Hevesaranyos: Kis-Ecser (SJ); Váraszó: Gödrösi, Patakverej; Uh: Borsodnádasd: Dér-tető (BÁ). CEU: [7887.4], [7986.2], [7986.4], [7987.1], [7987.3].

2028. Scorzonera austriaca L. - Meszes sztyepréteken, borókásokban, homokkősziklagyepekben. Tv: Bükkszenterzsébet: Vár-magas; Pétervására: Lyukas-kő - Herb.: 2007.4.30. (BÁ); Szentdomonkos: Nagy-Ormos-hegy, Pusok (SJ); Tarnalelesz: Henc-ortvány (BÁ); Óm: Borsodnádasd: Szalinca (SJ); Pm: Bükkszenterzsébet: Szőlő-megi-hegy - $\underline{\text { Herb.: }}$

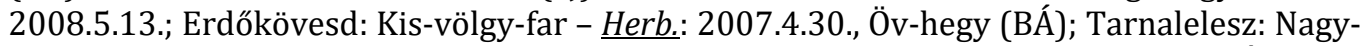
hegyesse (SJ); Váraszó: Gödrösi, Patakverej - Herb.: 2008.5.13., Vagdaszó-bérc (BÁ). CEU: [7887.4], [7986.2], [7986.4], [7987.1], [7987.3].

2037. Sonchus palustris L. - Patakok mentén, magaskórósokban, magassásosokban. Bh: Mónosbél: Turbács (SJ); Uhg: Dédestapolcsány: Felső-rét (BÁ), Veszett-szög; Nekézseny: Szőlő-mál-tető; Tv: Borsodnádasd: Hasznos, Róna-Bükk-völgy; Borsodszentgyörgy: Kalitka-völgy, Szentgyörgyi-patak-völgye; Domaháza: Asztag-völgy, Felső-völgy, Fülek-vára, Hangony-völgy, Hintós-völgy, Miklós-fája, Nagy-völgy, Son-torok, Széles-Imola-völgy, Tóvölgye-patak; Hangony: Hangony-völgy, Kő-völgy, Mihászó-völgy, Petyke-völgy, Szilakszóvölgy; Istenmezeje: Tarna-völgye; Járdánháza: Cselény-völgy; Ózd: Harmaci-völgy, Hegymegi-völgy; Sajópüspöki: Nagy-völgy (SJ); Zabar: Szekeres-bükk-völgy (BÁ), Zabar-völgy; Óm: Arló: Szentgyörgyi-patak-völgye; Borsodnádasd: Árkos-völgy; Ózd: Hangony-patak; Pm: Tarnalelesz: Bokor-völgy; Uh: Arló: Arlói-tó, Bagó-lápa, Szohony-völgy; Csokvaomány: Felső-rét; Királd: Kerek-rét; Sajómercse: Mercse-patak, Mercse-patak-völgye; Sajónémeti: 
Királd-patak (SJ). CEU: [7786.4], [7787.1], [7787.3], [7788.1], [7788.2], [7788.3], [7886.1], [7886.2], [7886.3], [7887.1], [7887.2], [7887.3], [7887.4], [7888.1], [7888.2], [7986.1], [7987.1], [7987.4].

2039. Lactuca perennis L. - Sziklagyepekben és homokkőtörmelékes erdőkben. Uhg: Dédestapolcsány: Nagy-hegy, Nagy-hegyi-szőlő, Nagy-hegy-orom; Nekézseny: Avas-bérc; Uppony: Cibróka, Kalica-tető; Tv: Bükkszenterzsébet: Közép-Berek; Pétervására: Fehér-kő Herb.: 2007.9.30.; Szentdomonkos-Tarnalelesz: Henc-ortvány (BÁ). CEU: [7788.4], [7888.2], [7986.1], [7986.2], [7987.1].

2040. Lactuca viminea (L.) J. Presl et C. Presl - Homokkő-sziklagyepben és melegkedvelő tölgyesben. Tv: Pétervására: Lyukas-kő, Remete-vár (BÁ). CEU: [7986.3].

2045. Prenanthes purpurea L. - Bükkösökben. Uhg: Uppony: Lázbérci-víztároló, Vízköz; Tv: Arló: Elő-Poporó, Gyepes-völgy, Nagy-hát-Sertés, Nyír-völgy, Ökör-hegy, Pataj-fő (SJ); Tarnalelesz: Pénzes-hegy, Vállós-völgy (BÁ). CEU: [7788.4], [7886.4], [7887.3].

2048. Taraxacum serotinum (Waldst. et Kit.) Poir. - BERÁNEK (2007) adatai a Szil-tető vonulat magasabb hegyeire vonatkoznak (Szil-tető, Szilas-alja-hegyese). Óm: Ózd: Szilas-tető - a Szil-tető keleti, legalacsonyabb hegyének déli oldalában löszös félszáraz gyepben. (SJ). CEU: [7787.4].

2049. Taraxacum laevigatum agg. - Száraz gyepekben, sziklagyepekben. Bh: Hevesaranyos: Veres-hegy; Uhg: Uppony: Upponyi-szoros; Tv: Arló: Közép-Poporó; Pm: Fedémes: Kútos-tető; Hevesaranyos: Kis-verő; Tarnalelesz: Kastály-legelő, Nagy-hegyesse (SJ). CEU: [7788.4], [7887.3], [7986.4], [7987.3].

2051. Taraxacum palustre agg. - Mindössze néhány egyéb aktuális előfordulása ismert a Matricumban [1]. Aggtelek és Tornaszentjakab határából VIRók et al. (2004) említi. Új a

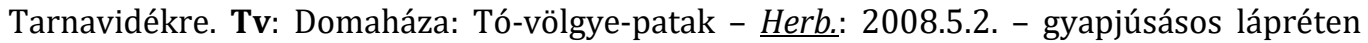
(BÁ). CEU: [7886.2].

2054. Crepis rhoeadifolia M. Bieb. - Zavartabb homoki gyepben. Pm: Bükkszenterzsébet: Kajtásza - Herb.: 2017.6.23. (BÁ). CEU: [7986.2].

2058. Crepis praemorsa (L.) Walther - Szálkaperjés gyepekben, mezofil erdőszegélyekben ritka. Bh: Hevesaranyos: Nagy-lápa-tető; Uhg: Dédestapolcsány: Nagy-hegy, Nagy-hegyiszőlő, Sár-bérc; Uppony: Dedevár (SJ). CEU: [7788.4], [7888.2], [7987.3].

2138. Triglochin palustre L. - A fajnak mindössze három adata ismert a kutatási területről: Zabar község határában 1868.8.1-én gyűjtötte Borbás Vince (BP-626376), Csernely mellett Budai József szedte 1909.6.1-én (BuDAI 1914 - BP-2345), valamint Suba János közli az arlói Gyepes-völgyből Kovács-Margit és Máthé Imre levele alapján (SuBA 1969). Igen kevés aktuális adatát találjuk az Északi-középhegységben, a Tarnavidékhez legközelebb Magos Gábor találja Mátraderecske határából 2004-ben [1]. Tv: Domaháza: Son-torok - lápréten 5 egyed (SJ). CEU: [7886.2].

2149. Colchicum autumnale L. - Üdébb, árnyasabb rétek és erdőszélek növénye. A Tarnavidéken - az eddigi adatok alapján - csak a Gömöri-erdőhát vonulatain fordul elő, melyet már Katona (2006) is megemlít. A Bükk északi előterében már jóval gyakoribb. Tv: Ózd: Csonkás, Nagy-oldal; Uh: Csokvaomány: Andornak, Szőlő-völgy - a Szőlő-völgy-főtől északra eső völgy (BÁ). CEU: [7787.1], [7888.1].

2153. Ornithogalum boucheanum (Kunth) Asch. - Tv: Sajópüspöki: Lapis, Szurdok - völgytalpon lévő gyertyános-tölgyes zavart szegélyében (SJ). CEU: [7787.2], [7788.1].

2155. Ornithogalum brevistylum Wolfner - Enyhén löszös talajú sztyepréteken, szálkaperjés és zavart gyepekben, néha parlagokon. Bh: Bekölce: Kút-lápa-tető - a Bogdánytól délkeletre lévő 400 m-es hegy (BÁ); Uhg: Bánhorváti: Hosszú-berek; Borsodbóta: Kotyindó-tető, Menyhárt; Dédestapolcsány: Bán-völgy, Halabuka-tető, Kerek-domb, Köszörűs és varjas (SJ), Nagy-hegy (BÁ), Nagy-hegy-alja, Nagy-hegy-orom (SJ), Sár-bérc (BÁ); Sáta: Hosszak és Kéri-tó, Kotyindó-tető; Tv: Ózd: Meleg-oldal (SJ); Pm: Fedémes: Árpaszó-hegy, Meggyes- 
lápa (SJ); Uh: Balaton: Varjas; Borsodnádasd: Balatoni-tető (BÁ); Csernely: Alsó-Nyékes; Csokvaomány: Pap-hegyese; Sajómercse: Gógány, Körtvélyes, Nagy-hegy, Szarvaskút, Szörnyü-völgy (SJ); Sajónémeti: Rátos, Rátos-tető (BÁ). CEU: [7787.3], [7787.4], [7788.1], [7788.3], [7887.4], [7888.1], [7888.2], [7987.2], [7987.3].

2159. Ornithogalum umbellatum L. s. l. - Mészkősziklagyepben. Uhg: Uppony: Upponyiszoros (BÁ). CEU: [7788.4].

2162. Scilla kladnii Schur - A Sajó-völgyéhez közel eső állományok üdébb, völgyi-, völgyközeli gyertyános-tölgyesekben és hárselegyes erdőkben fordulnak elő. A közeli Putnokidombságból MALATINSZKY (2007) közli adatát. Az Upponyi-hegységre és a Tarnavidékre új. Uhg: Sajómercse: Czimer-halom, Határ-völgy; Tv: Sajópüspöki: Lapis, Lapis-fő, Piszkor-fő (SJ), Szőlő-tető, Szurdok (SJ-BÁ); Uh: Sajóvelezd: Vár-erdő (SJ). CEU: [7787.2], [7788.1], [7788.2].

2172. Allium sphaerocephalon L. - Homokkő-sziklagyepekben, sztyepréteken. Bh: Bekölce: Perekonya-bérc; Tv: Domaháza: Gyalogút-lápa; Hangony: Kis-berek-bérc (SJ); Pétervására: Lyukas-kő - Herb.: 2009.7.19. (BÁ); Sajópüspöki: Kőfeli; Szentdomonkos: Kő-hegy, NagyOrmos-hegy, Pusok; Váraszó: Kő-orom; Óm: Borsodnádasd: Szalinca (SJ); Pm: Erdőkövesd: Öv-hegy - Herb.: 2009.7.19. (BÁ); Hevesaranyos: Buja-hegy; Szentdomonkos: Tormás-hegy (SJ); Tarnalelesz: Kovács-had - Herb.: 2008.7.13. (BÁ), Lóhát-orom, Tormás-hegy; Uh: Arló: Szohony (SJ). CEU: [7786.4], [7788.1], [7886.2], [7887.2], [7887.4], [7986.2], [7986.3], [7986.4], [7987.1], [7987.2].

2187. Allium lusitanicum Lam. - Sziklagyepekben, mészkerülő erdőkben. Uhg: Dédestapolcsány: Bender-bérc, Éles-kő-tető, Nagy-erdő, Sár-oldal; Nekézseny: Fehér-kő; Uppony: Upponyi-szoros; Tv: Arló: Nagy-barlang-völgy, Nagy-Poporó, Remete-bérc (SJ); Pétervására: Fehér-kő - Herb.: 2007.9.30; Váraszó: Köves-út (BÁ); Pm: Fedémes: Kútos-tető (SJ). CEU: [7788.4], [7887.3], [7888.2], [7986.1], [7986.2], [7987.3].

2190. Allium flavum L. - Sziklagyepekben. Uhg: Dédestapolcsány: Nagy-hegy-orom; Tv: Hangony: Nagy-Golotka (BÁ). CEU: [7786.4], [7888.2].

2192. Convallaria majalis L. - Üdébb lomberdők és erdőszélek növénye. Uhg: Dédestapolcsány: Nagy-hegyi-szőlő, Rigó-tető; Nekézseny: Avas-bérc; Uppony: Vízköz; Tv: Borsodnádasd: Ulnai-Bikkfő; Istenmezeje: Hagymás-eleje; Pétervására: Lajos-patak-árnyék; Óm: Borsodnádasd: Karácsonylova-völgy, Uh: Borsodnádasd: Csiterkötő, Vásáros-úti-völgy; Csokvaomány: Szilfás, Vén-szőlő (BÁ). CEU: [7788.4], [7887.3], [7887.4], [7888.1], [7888.2], [7986.1], [7987.2].

2193. Maianthemum bifolium (L.) F.W. Schmidt - Üdébb, - általában völgyközeli - mészkerülő bükkösök növénye. Bh: Borsodnádasd: Bánya-fölött (BÁ); Uhg: Sajómercse: Mercseágazat; Uppony: Lázbérci-víztároló; Tv: Arló: Nyír-völgy, Virág-bérc, Zsá-völgy (SJ); Borsodnádasd: Ulnai-Bikkfő (BÁ); Hangony: Halyág-bérc, Vizes-völgy-fő (SJ); Istenmezeje: Alsó-Szerpatak-gödre, Felső-Kajra-völgy, Görbe-fő, Hagymás-völgy (BÁ); Kissikátor: Oldal-úttető; Váraszó: Csókás-völgy (SJ), Forró-kút-lápa, Hosszú-ág-lápa, Hosszú-rét (BÁ), Kenyérdomb (SJ), Nagy-Lugzós, Szénégető-hegyese; Óm: Borsodnádasd: Karácsonylova-völgy, Uh: Borsodnádasd: Csiterkötő, Csiterkötő-tető, Vásáros-úti-völgy (BÁ). CEU: [7786.4], [7788.4], [7886.2], [7886.3], [7886.4], [7887.1], [7887.3], [7887.4], [7986.1], [7987.2].

2199. Paris quadrifolia L. - Égerligetekben, völgytalpi gyertyános-tölgyesekben és bükkösökben, szurdokerdőkben. Tv: Arló: Barlang-tető - $\underline{\text { Herb.: }}$ 2006.4.30. (BÁ), Barlang-tetővölgy - a Vajda-vár-völgy végének keleti oldalága, Elő-Poporó, Halonna-bérc, Kereszt-völgy, Nagy-barlang-völgy, Nyilakó-völgy, Nyír-völgy, Szedres-ág-bérc, Szúnyogos, Vajda-várvölgy, Vészverés-bérc, Vészverés-völgy, Vizes-lápa-bérc, Zár-fö (SJ), Zár-rét; Borsodnádasd: Dögkert-völgy - Herb.: 2007.5.15., Kerek-hegy - Herb.: 2007.4.29. (BÁ); Borsodszentgyörgy: Csanálos-bérc, Teresznek-far-tető (SJ); Hangony: Biriny-völgy, Halyág-bérc (BÁ), István-kút-tető, Petyke-völgy, Vizes-völgy-fő (SJ); Istenmezeje: Alsó-Szerpatak-gödre, Bé- 
kák-bérc, Felső-Kajra-völgy, Hagymás-völgy, Hegyes-kukucsa, Hosszú-orom, Nagy-Csengős (BÁ); Kissikátor: Tiszta-tető (SJ); Tarnalelesz: Vállós-völgy; Váraszó: Cseres-lápa, Forrókút-lápa, Herceges (BÁ), Kenyér-domb (SJ), Len-ág, Nagy-Herceg, Nagy-Lugzós, Patak-fő (BÁ), Váraszói-völgy (SJ), Verő-lápa; Uh: Borsodnádasd: Vásáros-úti-völgy (BÁ); Csernely: Nagy-Horsó-tető (SJ); Csokvaomány: Szőlő-völgy (BÁ). CEU: [7786.4], [7886.2], [7886.3], [7886.4], [7887.1], [7887.3], [7887.4], [7888.1], [7985.2], [7986.1].

2228. Gagea bohemica (Zauschn.) Schult. et Schult. f. - A Gagea bohemica elsősorban a Mátrából ismert, a Bükkből csak Prodán Gyulának van publikált adata. Az ismert előfordulásokat a területre vonatkozóan BAUER et al. (2002) foglalja össze. Egerbakta és Bátor bazalt vonulatainak sziklakibúvásain viszont többfelé is előfordul (Sulyok József ined., Erős Róbert [1]). Az Upponyi-hegységre új. Uhg: Uppony: Három-kő - andezitszikla tetején lévő sziklagyepben kb. 70 egyed (SJ). CEU: [7788.4].

2235. Lilium martagon L. - Üde gyertyános-tölgyesekben és bükkösökben. Bh: Hevesaranyos: Köszörűs; Uhg: Bánhorváti: Éles-kő, Éles-kő-tető; Dédestapolcsány: Derennek-völgy, Hosszú-berek-tető, Lázbérci-víztároló; Nagyvisnyó: Somos-cserje (SJ); Nekézseny: Sutavölgy (BÁ); Sajómercse: Czimer-halom, Hársas-erdő; Uppony: Bender-oldal (SJ), Csernelypatak-völgye (BÁ), Dedevár, Eszkála-tető (SJ), Kalica-tető (BÁ), Lázbérci-víztároló (SJ), Upponyi-szoros, Vízköz (BÁ), Vízköz-szoros, Zsellér-földek; Tv: Arló: Nagy-hát-Sertés; Uh: Sajómercse: Mazsúr-völgy - a Mazsúrtól keletre eső völgy; Sajóvelezd: Vár-erdő (SJ). CEU: [7788.1], [7788.2], [7788.4], [7887.3], [7888.2], [7888.4], [8087.1].

2241. Galanthus nivalis L. - Völgytalpi égerligetekben, gyertyános-tölgyesekben, bükkösökben, hárs-kőris sziklaerdőkben. Bh: Bátor: Laskó-völgy; Uhg: Bánhorváti: Éles-kő, Éleskő-tető, Lázbérci-víztároló; Nagyvisnyó: Somos-cserje; Sajómercse: Czimer-halom, Határvölgy; Uppony: Dedevár, Eszkála-tető, Fekete-kő-tető, Vízköz; Uh: Sajóvelezd: Vár-erdő (SJ). CEU: [7788.2], [7788.4], [7888.4], [8087.2].

2251. Iris pseudacorus L. - Tv: Borsodszentgyörgy: Palina-völgy, patakmenti növényzetben (BÁ). CEU: [7886.2].

2258. Iris $\times$ germanica L. - Felhagyott gyümölcsösökben kivadulva. Bh: Bükkmogyorósd: Szőlő-hegy; Uhg: Dédestapolcsány: Halabuka-tető, Varjas-szőlő (SJ); Uh: Csokvaomány: Andornak (BÁ). CEU: [7888.1], [7888.2], [7888.3].

2260. Iris variegata L. - Cseres-tölgyesekben, sztyepréteken, szálkaperjés gyepekben, erdőszegélyekben. Uhg: Bánhorváti: Nagy-oldal; Borsodbóta: Veres-tető; Dédestapolcsány: Balta-tető, Halabuka-tető, Nagy-hegy; Nagyvisnyó: Somos-cserje (SJ); Nekézseny: Avas-bérc (BÁ); Uppony: Lázbérci-víztároló; Tv: Arló: Futyóköz-orma, Nagy-barlang-völgy, Remetevölgy, Szedres-ág-bérc (SJ); Bükkszenterzsébet: Nagy-kő; Istenmezeje: Kőhártya-tető; Pétervására: Vaskapu (BÁ); Pm: Tarnalelesz: Lóhát-orom; Uh: Borsodbóta: Őr-hegy; Csokvaomány: Babos (SJ). CEU: [7788.3], [7788.4], [7887.3], [7888.1], [7888.2], [7888.4], [7986.1], [7986.2], [7986.3], [7986.4].

2290. Luzula multiflora (Ehrh.) Lej. - A faj elterjedéséről viszonylag kevés adat áll rendelkezésre. A legközelebbi előfordulása a Karancsról (CSIKY \& JUDIK 1998, CsIKY 2004), ismert, valamint a Bükkből vannak a múlt század elejéről származó adatok (Prodán 1909, Soó 1943, VojтKó 2001). Új a Tarnavidékre. Tv: Domaháza: Miklós-fája - Herb.: 2006.6.4., forráslápon (BÁ). CEU: [7886.2].

2295. Festuca drymeja Mert. et W.D.J. Koch - Üde bükkösökben ritka. Uhg: Dédestapolcsány: Lipóc-völgy; Uppony: Bender-bérc (SJ). CEU: [7788.4], [7888.2].

2316. Festuca pseudovina Hack. - Utak mentén, behurcolva. Tv: Borsodszentgyörgy: Palina-völgy; Uh: Balaton: Lencsés-völgy (SJ). CEU: [7887.1], [7887.4].

2325. Poa badensis Haenke ex. Willd. - Uhg: Uppony: Vízköz-szoros - sziklagyepekben. Régóta ismert adat, melyet elsőként Boros (1934) jegyez le, de VojтKó $(1995,2001)$ is többször említi. (SJ). CEU: [7788.4]. 
2327. Poa compressa L. - Homokkőtörmelékes gyepben gyakori. Tv: Bükkszenterzsébet: Dobogó-bérc - Herb.: 2007.6.17. (BÁ). CEU: [7986.2].

2346. Catabrosa aquatica (L.) P. Beauv. - Uh: Csokvaomány: Nemecke-árnyék - Herb.: 2008.5.15. - forrás kivezető csatornájában állományalkotó (BÁ). CEU: [7888.1].

2351. Sesleria hungarica Ujhelyi - Sziklagyepekben. A növény megtalálása szintén Budai József nevéhez füződik, aki „Sesleria Heufleriana Schur.” néven gyűjti 1912.5.5-én (BP10643) a mészsziklák északi oldalán az Upponyi-szorosban (BuDAI 1914). Uhg: Uppony:

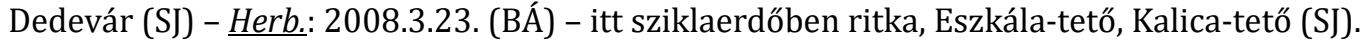
CEU: [7788.4].

2365. Glyceria notata Chevall. - Nedves árokban, patakmenti növényzetben, forrásnövényzetben. Számos korábbi adata van a tájegységből (Kovács 1962, SubA 1969). Tv: Borsodszentgyörgy: Palina-völgy - $\underline{\text { Herb.: }}$ 2005.7.11.; Ivád: Szent-völgy - Herb.: 2005.7.4.; Tarnalelesz: Vállós-völgy - Herb.: 2005.6.3. (BÁ). CEU: [7886.4], [7887.1], [7986.3].

2366. Glyceria nemoralis (Uechtr.) Uechtr. et Körn. - A "flóratérképezés” során talált növény új a Tarnavidékre. A kutatási területről még Vojtkó András jelzi Uppony mellől, a Csernely patak völgyéből (VojTKó 1994, 1995). Tv: Szentdomonkos: Csókás - égerligetben lévő forrásnövényzetben (SJ). CEU: [7987.1].

2472. Piptatherum virescens (Trin.) Boiss. - Sziklás melegkedvelő tölgyesekben. Uhg: Uppony: Fekete-kő-tető (SJ), Kalica-tető, Upponyi-szoros (BÁ). CEU: [7788.4].

2473. Stipa capillata L. - Sztyeprétek, homokkő-sziklagyepek gyakoribb növénye. Uhg: Dédestapolcsány: Éles-kő; Uppony: Eszkála-tető, Kalica-tető; Óm: Borsodnádasd: Szalinca; Pm: Fedémes: Alsó-sóska-hely, Árpaszó-hegy, Meggyes-oldal; Hevesaranyos: Buja-hegy (SJ); Pétervására: Alsó-lázi-dűlő, Repenye, Tiszán (BÁ); Tarnalelesz: Dancsok, Dancsok-far, Kastály-legelő, Nagy-hegyesse, Tormás-hegy (SJ); Váraszó: Öv-hegy, Títás, Vagdaszó-bérc (BÁ); Uh: Arló: Szohony; Csokvaomány: Liba-tető, Páter-oldal, Vasút-tető (SJ). CEU: [7788.4], [7887.2], [7887.3], [7887.4], [7888.1], [7986.2], [7986.4], [7987.1], [7987.3].

2475. Stipa tirsa Steven em. Čelak. - Sztyepréteken szórványos, erdőssztyepréteken állományalkotó. Az erdőssztyepréteken sokszor domináns faj a Mátra és a Bükk előterében nem ritka. Első adata az Upponyi-hegyhátból Csernelyről származik (SULYoK \& SCHMOTZER 1999). A Tarnavidékre új. Uhg: Bánhorváti: Nagy-oldal; Pm: Fedémes: Meggyes-lápa; Tarnalelesz: Csigdászó, Dancsok, Lóhát-orom, Meszes, Meszes-dűlő (SJ). CEU: [7788.4], [7986.4], [7987.3].

2477. Stipa pennata L. - Sztyeprétek, homokkő-sziklagyepek gyakoribb növénye. Bh: Egercsehi: Szőlő-mála; Hevesaranyos: Kopasz-orom; Uhg: Dédestapolcsány: Éles-kő, Nagyhegyi-szőlő, Somos-bérc; Nekézseny: Szégyen-tető; Sáta: Hosszak és Kéri-tó; Uppony: Kalica-tető; Tv: Bárna: Ceredi-határ (SJ); Bükkszenterzsébet: Köves-verő; Hangony: KisTartalóca - Herb.: 2008.5.31.; Istenmezeje: Noé szőlője - Herb.: 2007.5.18.; Pétervására: Gyupáros, Lyukas-kő, Lyukas-kő-hegy (BÁ); Sajópüspöki: Kőfeli (SJ); Tarnalelesz: Peskőtető - Herb.: 2008.6.1.; Váraszó: Dagasztó, Kő-orom (BÁ); Óm: Borsodnádasd: Szalinca (SJ);

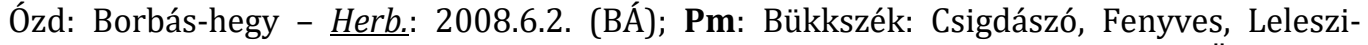
szállás, Lóhát-orom, Meszes-dűlő (SJ); Bükkszenterzsébet: Róna; Erdőkövesd: Öv-hegy Herb.: 2008.6.1. (BÁ); Fedémes: Árpaszó-hegy, Meggyes-oldal; Hevesaranyos: Buja-hegy; Tarnalelesz: Bolya-völgy, Dancsok, Dancsok-far, Fingászó-hegy-orma, Lóhát-orom, Madarászó, Meszes, Meszes-dúlő, Nagy-hegyesse (SJ); Uh: Arló: Benéte - Herb.: 2008.6.2., Szohony - Herb.: 2008.6.2., Vár-hegy - $\underline{\text { Herb.: }}$ 2008.6.2. (BÁ); Járdánháza: Szalinca; Királd: Őr-tető; Sajómercse: Körtvélyes, Őr-tető (SJ). CEU: [7787.3], [7787.4], [7788.1], [7788.3], [7788.4], [7885.4], [7887.2], [7887.4], [7888.1], [7888.2], [7986.1], [7986.2], [7986.3], [7986.4], [7987.2], [7987.3], [8087.1].

2479. Stipa pulcherrima K. Koch - Homokkő-sziklagyepek és ritkábban sztyeprétek, sziklafüves lejtők növénye. Uhg: Bánhorváti: Máli-oldal; Dédestapolcsány: Köszörűs és varjas; 
Uppony: Vízköz-szoros (SJ); Tv: Bükkszenterzsébet: Közép-Berek, Nagy-kő, Szappan-kő Herb.: 2008.5.13.; Hangony: Kis-Tartalóca - Herb.: 2008.5.31.; Istenmezeje: Kőhártya-tető Herb.: 2008.6.1., Tó-bérce - Herb.: 2008.6.1.; Pétervására: Vaskapu - Herb.: 2009.6.7. (BÁ); Szentdomonkos: Nagy-Ormos-hegy, Pusok; Óm: Borsodnádasd: Szalinca; Pm: Fedémes: Meggyes-lápa (SJ); Szentdomonkos: Kő-alja-hegy - Herb.: 2008.5.16. Uh: Járdánháza: Szalinca - Herb.: 2008.6.2.; Sáta: Őr-hegy - Herb.: 2008.6.2. (BÁ). CEU: [7786.4], [7788.3], [7788.4], [7887.4], [7888.2], [7986.1], [7986.2], [7986.3], [7987.1], [7987.3].

2485. Molinia arundinacea Schrank - Mészkerülő, többletvízhatásnak kitett félszáraz gyepekben, mocsárréteken. SULYOK \& SCHMOTZER (1999) Bükkmogyorósd: egres-völgyi és Szilvásvárad: szilvás-pataki $M$. hungarica adata is erre a fajra vonatkozik. Uh: Sajómercse: Körtvélyes (SJ). CEU: [7788.3], [7888.3].

2487. Cleistogenes serotina (L.) Keng - Sztyepréteken, melegkedvelő tölgyesek tisztásain, száraz borókások nyíltabb részein és homokkő-sziklagyepekben nem ritka. Uhg: Dédestapolcsány: Éles-kő-tető, Halabuka-tető, Sár-oldal, Somos-bérc; Nekézseny: Szőlő-mál-tető (SJ); Uppony: Cibróka, Eszkála-tető, Kalica-tető; Tv: Borsodszentgyörgy: Lyuk-hegy; Bükkszenterzsébet: Vár-magas; Hangony: Pogányvár; Istenmezeje: Nagy-Musák; Tarnalelesz: Henc-ortvány, Pataj-verő (BÁ); Váraszó: Kő-orom (SJ), Tó-hegyese (BÁ); Óm: Borsodnádasd: Szalinca; Pm: Bükkszenterzsébet: Szőlő-megi-hegy; Hevesaranyos: Víg István-tető (SJ); Szentdomonkos: Kő-alja-hegy; Tarnalelesz: Babar-tető; Váraszó: Öv-hegy (BÁ). CEU: [7787.3], [7788.4], [7886.4], [7887.1], [7887.4], [7888.1], [7888.2], [7986.2], [7986.4], [7987.1], [7987.3].

2521. Chrysopogon gryllus (L.) Trin. - Sztyepréteken, száraz gyepekben, melegkedvelő tölgyesek tisztásain gyakori. Délies gyepekben néhol állományalkotó. Uhg: Dédestapolcsány: Halabuka-tető, Nagy-hegyi-szőlő; Uppony: Eszkála-tető; Tv: Borsodnádasd: Karácsony-hegy; Domaháza: Aszaló-Bikk, Répás-verő, Szörnyű, Telek-felé; Hangony: Pogányvár; Ózd: Harmaci-völgy-fő; Pétervására: Lyukas-kő-hegy; Zabar: Östvény-tető; Óm: Ózd: Borbás-hegy; Pm: Bükkszenterzsébet: Szőlő-megi-hegy; Szentdomonkos: Kő-alja-hegy; Váraszó: Gödrösi; Uh: Borsodbóta: Csépány-tető; Borsodnádasd: Balatoni-tető, Budaberke, Mocsolyás-tető (BÁ). CEU: [7786.4], [7787.1], [7787.3], [7787.4], [7788.3], [7788.4], [7886.1], [7886.2], [7887.3], [7887.4], [7888.2], [7986.2], [7986.3], [7987.1].

2537. Sparganium erectum L. - Sekély mocsári növényzetben. Tv: Domaháza: Sózó-völgy; Uh: Csokvaomány: Nemecke-árnyék (BÁ). CEU: [7886.2], [7888.1].

2561. Scirpus sylvaticus L. - Égerligetekben, forrásnövényzetben, magassásosokban, patakok mentén. Uhg: Borsodbóta: Gyưre-völgy; Nekézseny: Szodonka-völgy - a nekézsenyi vasúti megálló völgye; Tv: Arló: Palina-völgy, Pap-kút, Remete-völgy, Zár-rét, Zsá-völgy; Borsodszentgyörgy: Nagy-Járnok-völgy, Palina-puszta, Patak-völgy (SJ), Üsnök-völgy Herb.: 2006.6.3. (BÁ), Vizes-völgy; Váraszó: Hosszú-völgy, Kenyér-domb, Kis-dél, Molnárlápa; Pm: Tarnalelesz: Bolya-völgy (SJ). CEU: [7788.3], [7886.2], [7886.4], [7887.1], [7887.3], [7888.2], [7986.4].

2563. Blysmus compressus (L.) Panz. - Taposott üde réteken és lápréteken. Bár a fajnak a Tarnavidéken és a Bükk északi előterében van még néhány előfordulása (BERÁNEK 2008, SuLYoK \& SCHMOTZER 1999), ezt leszámítva igen ritka az Északi-középhegységben [1], még egy-egy aktuális adattal a Bükkből (GuLYÁs \& VIRóK 2000) és a Nógrád megyei Ságújfalu határából (CsikY et al. 1999). Tv: Domaháza: Benedek-völgy - Herb.: 2007.6.2. (BÁ), Hintósvölgy (SJ), Keselyűs-Bikk-völgy, Nagy-völgy (BÁ). CEU: [7886.1], [7886.2].

2565. Eriophorum angustifolium Honck. - Lápréteken, forráslápokban. Tv: Hangony: Mihászó-völgy - Herb.: 2008.5.18. (BÁ); Óm: Arló: Szentgyörgyi-patak-völgye, Uh: Arló: Arlóitó, Izra-völgy (SJ); Királd: Kerek-rét - $\underline{\text { Herb.: }}$ 2008.5.15. (BÁ); Sajómercse: Szörnyü-völgy (SJ). CEU: [7787.3], [7788.3], [7887.1], [7887.2].

2566. Eriophorum latifolium Hoppe - Lápréteken, forráslápokban. Tv: Borsodszentgyörgy: 
Kántor-lápa (BÁ); Domaháza: Son-torok; Járdánháza: Cselény-völgy (SJ); Zabar: Zabarvölgy; Uh: Arló: Arlói-tó - Herb.: 2007.5.14. (BÁ), Bagó-lápa, Vár-hegy (SJ). CEU: [7886.2], [7886.3], [7887.1], [7887.2], [7887.4].

2579. Cyperus fuscus L. - Taposott lápi és mocsári növényzetben, nyíltabb iszapos felszíneken. Tv: Borsodszentgyörgy: Üsnök-völgy; Domaháza: Keselyűs-Bikk-völgy, Son-torok; Ivád: Szent-völgy; Pétervására: Szent-völgy; Uh: Csokvaomány: Nemecke-árnyék (BÁ). CEU: [7886.2], [7887.1], [7888.1], [7986.3].

2592. Carex ovalis Gooden. - Üde erdőszéli mészkerülő gyepekben és nedves erdőgazdasági utakon ritka. Bh: Borsodnádasd: Bánya-fölött; Tv: Borsodszentgyörgy: Palina-völgy; Hangony: Kis-Tartalóca-völgy - $\underline{\text { Herb.: }}$ 2008.5.31.; Szentdomonkos: Ferenc-tető; Tarnalelesz: Pénzes-hegy, Tódor-láb-hegyese, Vízválasztó; Váraszó: Fenekes-völgy - Herb.: 2007.6.4., Vaskapu; Uh: Ózd: Kígyós-völgy (BÁ). CEU: [7787.3], [7886.4], [7887.1], [7887.2], [7887.4], [7987.1].

2603. Carex paniculata L. - Patakmenti árnyas magassásosokban ritka. A faj az Északiközéphegységben igen szórványos. A legközelebbi adata Csokvaományból származik (SULYOK \& SCHMOTZER 1999). Új a Tarnavidékre. Tv: Váraszó: Hosszú-ág-lápa - Herb.:

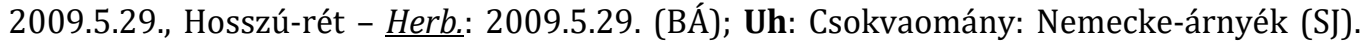
CEU: [7886.4], [7888.1].

2604. Carex appropinquata Schumach. - Tv: Bükkszenterzsébet: Erzsébeti-völgy - Herb.: 2015.6.4. - mindössze két töve erdei forráslápfolton, vízfolyás mentén, Caltha palustris, Carex flacca, Impatiens noli-tangere, mentafajok és Scirpus sylvaticus társaságában. Az Északi-középhegységben még két aktuális adata ismert [1], SzMORAD (1999) említi a Bódvavölgyből, valamint Vojtkó András találja Nagyhutánál (Zempléni-hg.) 2005-ben [1]. Új a Tarnavidékre. (BÁ). CEU: [7986.2].

2610. Carex elata All. - A Bükkhát területén a „flóratérképezés” során Penksza Károly találta még 2003-ban Csokvaomány környékén [1]. Bh: Lénárddaróc: Alsó-hosszas - magassásosban 80 zsombék (SJ). CEU: [7888.1].

2612. Carex nigra (L.) Reichard - Lápréteken, forráslápokban. Tv: Borsodszentgyörgy: Kántor-lápa - Herb.: 2007.5.17.; Hangony: Mihászó-völgy - Herb.: 2008.5.18. (BÂ); Óm: Borsodnádasd: Hódos-patak-völgye; Uh: Arló: Csahó-völgy, Izra-völgy, Vár-hegy; Balaton: Lencsés-völgy; Sajómercse: Szörnyü-völgy (SJ). CEU: [7787.3], [7788.3], [7887.1], [7887.2], [7887.3], [7887.4].

2613. Carex buekii Wimm. - Égerligetek szegélyében, patakok mentén foltokban állományalkotó. Bh: Bekölce: Bekölcei-patak-völgye; Lénárddaróc: Alsó-hosszas, BERÁNEK (2008) Lénárddaróc: Csernely-patak adata ide vonatkozik; Mikófalva: Bekölcei-patak-völgye; Mónosbél: Turbács; Uhg: Borsodbóta: Gyüre-völgy; Dédestapolcsány: Éger-alja; Nekézseny: Felsővölgy, Sátai-patak-völgye; Uppony: Alsó-völgy, Csernely-patak-völgye, Vízköz-szoros (SJ); Tv:

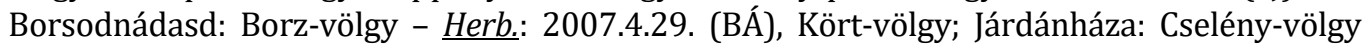
(SJ); Ózd: Malom-verő-lápa - Herb.: 2007.5.27.; Óm: Arló: Hódos-patak-völgye - Herb.: 2007.5.14. (BÁ), Uh: Arló: Arlói-tó, Bagó-lápa; Csokvaomány: Alsó-rét, Felső-rét, Nemecke-árnyék (SJ); Sajómercse: Mercse-patak - Herb.: 2007.5.1. (BÁ), Nyúzó-völgy (SJ); Sajónémeti: Királd-patak - Herb.: 2007.5.13. (BÁ). CEU: [7787.2], [7788.1], [7788.2], [7788.3], [7788.4], [7887.2], [7887.3], [7887.4], [7888.1], [7888.2], [7888.3], [7987.2], [7987.4].

2614. Carex cespitosa L. - Mocsárréteken, magassásosokban. Legközelebbi adata a Bükkhátról Csokvaomány, Lénárddaróc, Bükkmogyorósd és Szilvásvárad (SULYOK \& SCHMOTZER 1999), valamint a Putnoki-dombságból, Zubogy mellől származik [1] (PEnKSZA \& MALATINSZKY 2001). Bh: Bükkmogyorósd: Egres-völgy; Uh: Csokvaomány: Alsó-rét, Felső-rét (SJ). CEU: [7888.1], [7888.3].

2636. Carex pallescens L. - Tv: Kissikátor: Két-ág-lápa - Herb.: 2004.5.12. - üde mészkerülő réten (BÁ). CEU: [7886.2]. 
2639. Carex riparia Curtis - A korábban Csokvaomány, Királd és Lénárddaróc határából említett néhány $C$. vesicaria néven említett adat (BERÁNEK 2008) is erre a fajra vonatkozik.

Uhg: Nekézseny: Fonatság - $\underline{\text { Herb.: }}$ 2009.6.16. - magassásosban; Uh: Királd: Királd-patak Herb.: 2016.5.25. - nyíltabb égeresben szórványos (BÁ). CEU: [7788.3], [7888.2].

2645. Carex panicea L. - Lápréteken szórványos. Uhg: Sáta: Tőkés-völgy (SJ); Tv: Borsodszentgyörgy: Kántor-lápa - Herb.: 2007.5.17., Teresznek-völgy (BÁ); Domaháza: Felsővölgy (SJ), Son-torok - Herb.: 2008.5.18.; Hangony: Mihászó-völgy - Herb.: 2008.5.18. (BÁ); Óm: Járdánháza: Hódos-patak-völgye; Ózd: Nagy-fák-alja; Pm: Tarnalelesz: Bokor-völgy;

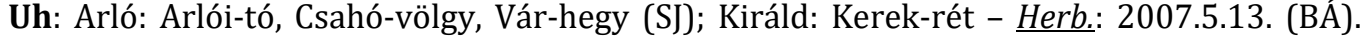
CEU: [7787.3], [7787.4], [7788.3], [7886.2], [7887.1], [7887.2], [7887.4], [7888.1], [7987.1].

2647. Carex michelii Host - Délies kitettségű tölgyesben és sztyepréten. Tv: Tarnalelesz: Futyóköz-orma - Herb.: 2008.5.4.; Uh: Sajónémeti: Nagy-hegy - Herb.: 2017.4.9. (BÁ). CEU: [7788.1], [7886.4].

2649. Carex hordeistichos Vill. - Erősen taposott üde réteken ritka. Tv: Domaháza: Széles-

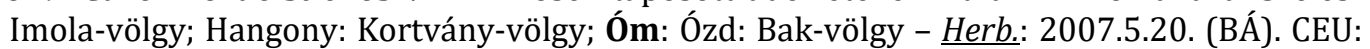
[7787.3], [7886.2].

2651. Carex flava L. - Üde láprétek, forráslápok ritka növénye. Tv: Borsodszentgyörgy:

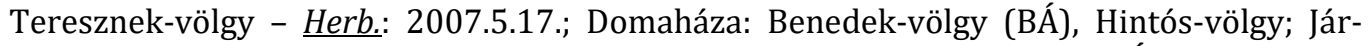
dánháza: Cselény-völgy (SJ); Uh: Arló: Csahó-völgy - Herb.: 2007.5.17. (BÁ); Sajómercse: Mercse-patak-völgye (SJ). CEU: [7788.3], [7886.1], [7886.2], [7887.1], [7887.2], [7887.3].

2657. Cypripedium calceolus L. - Bh: Hevesaranyos: Dóna-útja-bérc - fiatal bükkösben 6 egyed. Valószínűleg ez a lelőhely is a BAKALÁRné et al. (1982-83) által Dancsortvány néven publikált lelőhelyhez tartozik, de attól valamivel távolabb helyezkedik el. A termőhelyet a megnevezett cikk társszerzője, Takács Béla útmutatásai alapján találtuk meg (SJ). CEU: [8087.1].

2658. Epipactis palustris (L.) Crantz - Lápréteken, forráslápokban. Uhg: Nagybarca: Kurittyán-tető - többletvízhatásnak kitett erodált szálkaperjés gyepben, szőlők között; Tv: Domaháza: Nagy-völgy; Hangony: Hangony-völgy (SJ), Kortvány-völgy (BÁ); Uh: Sajómercse: Mercse-patak-völgye (SJ). CEU: [7787.3], [7788.3], [7789.1], [7886.2].

2659. Epipactis microphylla (Ehrh.) Sw. - Melegkedvelő tölgyesekben, bükkösökben, gyertyános-tölgyesekben, sziklaerdőkben. Bh: Borsodnádasd: Bánya-fölött (BÁ); Hevesaranyos: Darcsontvány, Dóna-útja-bérc, Ecser-bükk, Ecser-hegy, Harasztos-hegyese, Őr-hegy-laposa; Sirok: Dorongos-tető; Uhg: Dédestapolcsány: Bender-bérc, Sár-oldal; Nekézseny: Szőlőmál-tető; Uppony: Bender-bérc, Bender-oldal, Kalica-tető, Vízköz, Zsellér-földek; Tv: Arló: Kis-Poporó, Közép-Poporó, Nádú-bérc, Nagy-hát-Sertés, Nyír-völgy (SJ); Domaháza: KerekBükk (BÁ), Nyárjasság; Hangony: Kis-berek-bérc (SJ); Istenmezeje: Kőhártya-tető (BÁ); Járdánháza: Köves-hegy (SJ); Pétervására: Lyukas-kő-hegy, Szénégető-völgy, Vaskapu; Tarnalelesz: Burja-hegyese, Pataji-far (BÁ); Váraszó: Nyárjas-völgy; Uh: Arló: Izra, Ladány-tető, Lőrinc-árnyéka, Macó-bérc, Szohony (SJ); Borsodnádasd: Balatoni Cseres-bérc, Balatonitető, Csiterkötő, Mesgye-hegy, Vásáros-úti-völgy (BÁ); Csernely: Varnyas-orom; Járdánháza: Szalinca; Királd: Mazsúr, Nyúzó-bérc, Ôr-tető; Sajómercse: Nagy-hegy (SJ). CEU: [7786.4], [7788.1], [7788.3], [7788.4], [7886.1], [7886.2], [7886.4], [7887.2], [7887.3], [7887.4], [7888.2], [7888.3], [7986.1], [7986.3], [7987.2], [7987.3], [8087.1].

2660,2. Epipactis leptochila (Godfery) Godfery subsp. neglecta (Kümpel) Kümpel - Gyertyános-tölgyesekben, bükkösökben szórványos. Az 1999-ben (SULYOK \& SCHMOTZER 1999) Arló: Közép-Poporó-völgy és Vajda-vár néven Epipactis helleborineként publikált adatok valójában erre a fajra vonatkoznak. A Bükkben nem ritka fajnak számos előfordulása került elő a dombvidékről, amelyek a „Magyarország orchideáinak atlasza”-ban már feltüntetésre kerültek (MoLNÁR 2011). Az alábbiakban részletesen felsoroljuk a tényleges lelőhelyeket, amelyek újak a tájegységekre. Bh: Borsodnádasd: Nagy-orom; Szilvásvárad: Bikk-tető - 
SCHMOTZER (2004) Dobogó-tető néven publikált E. helleborine adata is E. neglecta; Uhg: Dédestapolcsány: Derennek-völgy, Lipóc, Lipóc-völgy, Nagy-hegy-orom, Sár-oldal; Uppony: Bender-bérc, Bender-oldal, Zsellér-földek; Tv: Arló: Gyepes-völgy, Nagy-hát-Sertés (SJ), Nyír-völgy (SJ-MVA), Ökör-hegy; Váraszó: Váraszói-völgy; Uh: Arló: Lőrinc-árnyéka, Macóbérc; Járdánháza: Szalinca (SJ). CEU: [7788.4], [7886.4], [7887.3], [7887.4], [7888.2], [7888.3], [7987.1].

2661. Epipactis voethii Robatsch - Üde bükkösökben ritka. A Nyír-völgy gyepes-völgyi torkolatából „Elő-Poporó” néven publikált Epipactis helleborinék (SULYOK \& SCHMOTZER 1999) egy része E. voethii-nek bizonyult. A faj legközelebbi előfordulásai a Bükkben vannak (MoLNÁR 2011). Új a Tarnavidékre. Tv: Arló: Nyír-völgy, Ökör-hegy (SJ-MVA). CEU: [7887.3].

2662. Epipactis pontica Taubenheim - Enyhén mészkerülő bükkösökben nem ritka. Tv: Arló: Elő-Poporó, Kis-barlang-bérc, Nádú-bérc, Nagy-barlang-völgy, Nagy-hát-Sertés, Nyírvölgy, Remete-bérc; Borsodnádasd: Nagy-Ormos-hegy; Borsodszentgyörgy: Üsnök-völgy, Vadberke; Domaháza: Boronás-padosa, Csobánkó, Körte-tető, Utas-árnyék; Istenmezeje: Tamás telke-fö, Víz-lápa-fő, Völgy-árnyék-bérc; Szentdomonkos: Borz-fő - a Hosszú-völgydűlőtől északkeletre eső 364,8 m-es hegy; Váraszó: Csókás-hegy, Farkas-lyuk-padja, Fenekes, Fenekes-völgy (SJ), Gemeruta-bérc (SA), Gemeruta-völgy, Hosszú-ágy, Kenyér-domb, Kerek-dél, Kis-dél, Nyárjas-völgy, Váraszói-völgy, Zelemér; Pm: Szentdomonkos: Akolmellett; Uh: Királd: Mazsúr (SJ). CEU: [7788.1], [7886.1], [7886.2], [7886.3], [7886.4], [7887.1], [7887.3], [7986.2], [7987.1].

2669. Epipactis albensis Nováková et Rydlo - A „Magyarország orchideáinak atlasza”-ban már feltüntetésre került az adat, amely új az Upponyi-hegységre. Legközelebb az ÉszakiBükkben és a Mátrában fordul elő (MoLNÁR 2011). Uhg: Uppony: Csernely-patak-völgye - a patak menti égerligetben két ponton 3 és 17 virágzó tő (SJ). CEU: [7788.4], [7888.2].

2671. Epipactis muelleri Godfery - Melegkedvelő tölgyesekben, erdőszegélyekben. Bh: Borsodnádasd: Nagy-orom; Bükkmogyorósd: Hangyás; Hevesaranyos: Darcsontvány, Dóna-útja-bérc, Harasztos-hegyese, Nagy-lápa-tető; Uhg: Nekézseny: Zsellér-földek; Uppony: Kalica-tető, Lázbérci-víztároló; Tv: Hangony: Kis-berek-bérc; Szentdomonkos: NagyOrmos-hegy; Óm: Ózd: Szil-tető; Uh: Arló: Ladány-tető, Szohony; Csernely: Lukács Gergelyesse, Nagy-Horsó-tető, Pete-fia, Úszó-fő, Varnyas-orom; Királd: Mazsúr; Sajómercse: Nagy-hegy (SJ). CEU: [7786.4], [7787.3], [7788.1], [7788.3], [7788.4], [7887.2], [7887.4], [7888.2], [7888.3], [7987.1], [7987.3], [8087.1].

2673. Epipactis helleborine (L.) Crantz - Gyertyános-tölgyesekben, bükkösökben, sziklaerdőkben. Bh: Borsodnádasd: Bánya-fölött (BÁ); Hevesaranyos: Dakó-hegye, Dóna-útja-bérc; Uhg: Bánhorváti: Éles-kő-tető, Hosszú-berek-tető; Dédestapolcsány: Lázbérci-víztároló, Nagy-erdő, Nagy-hegy-orom, Rádincs-völgy; Uppony: Bender-bérc, Eszkála-tető, Kalicatető, Lázbérci-víztároló, Vízköz, Zsellér-földek; Tv: Arló: Cseterna-bérc - a Cseterna délnyugati 421,7 és 442,6 m-es gerince, Ökör-hegy; Borsodnádasd: Kerek-berek-fő; Sajópüspöki: Kőfeli; Pm: Hevesaranyos: Kis-Ecser; Tarnalelesz: Meszes; Uh: Arló: Szohony; Csernely: Lukács Gergelyesse; Királd: Mazsúr (SJ). CEU: [7788.1], [7788.4], [7887.2], [7887.3], [7888.2], [7986.4], [7987.2], [7987.3], [8087.1].

2674. Epipactis purpurata Sm. - Szintén a „Magyarország orchideáinak atlasza”-ban már feltüntetésre kerültek az adatok (MoLNÁR 2011). A Tarnavidékről Bartha Csaba jelzi 2004ben [1]. Az upponyi adata új az Upponyi-hegységre. Bükkösökben ritka. Uhg: Uppony: Vízköz; Tv: Domaháza: Csobánkó (SJ). CEU: [7788.4], [7886.1].

2675. Cephalanthera rubra (L.) Rich. - Melegkedvelő tölgyesekben, tölgyes és bükkös sziklaerdőkben, mészkőtörmelékes vagy meszes talajú bükkösökben. Bh: Csernely: Bazsik; Hevesaranyos: Dóna-útja-bérc, Ecser-hegy, Harasztos-hegyese; Uhg: Dédestapolcsány: Hoszszú-berek-tető, Lipóc (SJ); Nekézseny: Avas-bérc, Strázsa-hegy (BÁ); Uppony: Bender-bérc, Bender-oldal, Dedevár, Eszkála-tető, Fekete-kő-tető, Kalica-tető, Lázbérci-víztároló, Zsellér- 
földek; Tv: Arló: Nagy-hát-Sertés (SJ); Hangony: Pogányvár (BÁ); Pm: Hevesaranyos: KisEcser; Uh: Arló: Lőrinc-árnyéka; Királd: Mazsúr, Ốr-tető (SJ). CEU: [7787.3], [7788.1], [7788.3], [7788.4], [7887.3], [7887.4], [7888.2], [7987.3], [8087.1].

2676. Cephalanthera damasonium (Mill.) Druce - Gyertyános-tölgyesek, bükkösök, sziklaerdők, ritkábban erdőszegélyek faja. Bh: Bátor: Megyaszó-fő, Pusok-tető; Borsodnádasd: Láz; Bükkmogyorósd: Alsó-sűrű-bérc, Alsó-sűrű-lápa, Csepegő-bérc, Csiga-völgy - a Kápolna-szállástól északra lévő völgy, Köves-orom, Salamon-vár; Csernely: Bazsik; Hevesaranyos: Dancs, Dóna-útja-bérc, Ecser-hegy, Körtélyes, Köszörűs, Megyaszó-fő, Nagy-lápa, Nagy-lápa-tető, Őr-hegy-laposa, Pusok-tető; Szilvásvárad: Salamon-vár; Uhg: Bánhorváti: Bárci-tető, Hosszú-berek; Dédestapolcsány: Bender-bérc, Éles-kő-tető, Lázbérci-víztároló, Lipóc (SJ), Nagy-hegy (BÁ), Nagy-hegyi-szőlő (SJ), Nagy-hegy-orom (BÁ); Nagybarca: Szeles-tető (SJ); Nekézseny: Avas-bérc (BÁ), Szőlő-mál-tető (SJ), Upponyi-tető - az Upponyivölgytől délre eső 348,7 m-es hegy (BÁ); Sajómercse: Mercse-ágazat; Sáta: Hosszak és Kéritó; Uppony: Bender-bérc, Bender-oldal (SJ), Cibróka, Csernely-patak-völgye (BÁ), Dedevár, Eszkála-tető, Fekete-kő-tető, Kalica-tető, Lázbérci-víztároló (SJ), Macskás, Upponyi-szoros, Vízköz (BÁ), Zsellér-földek; Tv: Arló: Gyepes-völgy, Nádú-bérc, Ökör-hegy; Borsodnádasd: Bán-berke, Fajdás-völgy, Karácsonylova, Kerek-berek-fő; Domaháza: Nyárjasság; Hangony: Kis-berek-bérc (SI); Istenmezeje: Görbe-fő, Kis-Kócsos-orom, Nagy-Kócsos-orom (BÁ); Járdánháza: Cseves, Köves-hegy (SJ); Ózd: Csonkás, Harmaci-völgy-fő, Nagy-oldal, Tótokerdeje, Vár-völgy, Zsófi János; Pétervására: Lyukas-kő (BÁ); Szentdomonkos: Borz-fő, NagyOrmos-hegy; Váraszó: Forró-kút-fő, Nyárjas-völgy (SJ), Váraszói-völgy; Zabar: Zabar-völgy (BÁ); Pm: Bükkszék: Pina-hegyes (SJ); Erdőkövesd: Ó-hegy (BÁ); Hevesaranyos: Ecserpatak völgye; Uh: Arló: Asszony-berki, Bagó-lápa, Izra-lápa - az Asszony-berkitől keletre eső völgy, Izra-völgy, Konnya-völgy, Ladány-tető, Lőrinc-árnyéka, Macó-bérc, Macó-völgy, Szohony (SJ); Borsodnádasd: Balatoni Cseres-bérc, Balatoni-tető, Budaberke, Csiterkötő, Mesgye-hegy, Mocsolyás-tető, Vásáros-úti-völgy (BÁ); Csernely: Borsostartó-tető (SJ), Csiga-hajas-oldal (BÁ), Eperjes, Horsó-puszta, Kerek-völgy-tető, Nemecke, Nyékes-tető, Petefia, Varnyas-orom; Csokvaomány: Nyékes-tető (SJ), Szilfás, Szőlő-völgy; Járdánháza: Mocsolyás (BÁ), Szalinca; Királd: Mazsúr, Nyúzó-bérc, Őr-tető; Sajómercse: Adár-bérc, Gógány, Nagy-hegy, Tarkai-parlag (SJ). CEU: [7786.4], [7787.1], [7788.1], [7788.3], [7788.4], [7789.1], [7886.2], [7886.3], [7886.4], [7887.1], [7887.2], [7887.3], [7887.4], [7888.1], [7888.2], [7888.3], [7986.1], [7986.3], [7986.4], [7987.1], [7987.2], [7987.3], [8086.2], [8087.1], [8087.2].

2676,1. Cephalanthera × schulzei A. Camus - A szülőfajai elterjedtek az Északiközéphegységben, ennek ellenére a hibridjük csak nagyon ritkán képződik. Egyedüli közelebbi adata csak a Bükkből ismert (TAKÁCS 1999). Új az Upponyi-hegyhátra. Uh: Csernely: Úszó-fő - meleg erdőszegélyben, félszáraz gyepben egyetlen tő, C. damasoniumokkal együtt (SJ). CEU: [7887.4].

2677. Cephalanthera longifolia (L.) Fritsch - Mészkerülő erdőkben, főleg bükkösökben, de gyertyános-tölgyesekben is. Uhg: Dédestapolcsány: Lázbérci-víztároló (SJ), Nagy-hegyorom; Tv: Domaháza: Répás-tető; Istenmezeje: Szép-orom (BÁ), Tamás telke-fő, Völgyárnyék-bérc; Váraszó: Csókás-hegy, Fenekes; Uh: Arló: Izra-völgy; Csernely: Borsostartótető; Királd: Őzvény-oldal (SJ). CEU: [7788.1], [7788.4], [7886.1], [7886.3], [7886.4], [7887.4], [7888.2], [7986.1].

2679. Epipogium aphyllum Sw. - Tv: Váraszó: Tölgyes-tető - a Tölgyes-lápától északnyugatra eső 430,4 m-es hegy. 2011. június 16-án a hegy melletti vízmosásban 2 virágzás elején lévő egyed, üde bükkösben; Váraszói-völgy - a völgy felső végében 500 méter hosszan elszórva a patak menti bükkösben 4 egyed. (SJ-SM) Az Északi-középhegységben még a Bükkből (SULYOK \& SULYOK 2011) és a Börzsönyből (NAGY et al. 2018) ismert. Új a Tarnavidékre. CEU: [7886.4]. 
2680. Neottia nidus-avis (L.) Rich. - Tölgyesekben és üde lomberdőkben nem ritka. Bh: Bátor: Pusok-tető; Bekölce: Eresztvény-hegy (SJ), Róna-bérc; Borsodnádasd: Bánya-fölött (BÁ), Róna-bérc; Bükkmogyorósd: Alsó-sürü-bérc, Alsó-sűrü-lápa, Csepegő-bérc, Csigavölgy, Köves-orom, Salamon-vár; Csernely: Bazsik; Hevesaranyos: Dóna-útja-bérc, Ecserbükk, Ecser-hegy, Köszörűs, Nagy-bügör, Nagy-lápa-tető, Pusok-tető, Vár-hegy; Uhg: Bánhorváti: Éles-kő-tető; Dédestapolcsány: Bender-bérc, Derennek-völgy, Éles-kő-tető, Hármas-határ, Hosszú-berek-tető, Lázbérci-víztároló, Lipóc, Lipóc-völgy, Nagy-erdő (SJ), Nagyhegyi-szőlő, Nagy-hegy-orom; Nekézseny: Avas-bérc, Bánya-alja, Bánya-oldal, Suta-völgy (BÂ), Szőlő-mál-tető (SJ), Upponyi-tető (BÁ); Sajómercse: Ấgazat-völgy, Mercse-ágazat; Uppony: Bender-bérc, Bender-oldal (SJ), Csernely-patak-völgye (BÁ), Dedevár, Eszkála-tető, Fekete-kő-tető, Kalica-tető, Lázbérci-víztároló (SJ), Upponyi-szoros (BÁ), Zsellér-földek; Tv: Arló: Barlang-tető, Barlang-tető-völgy, Elő-Poporó, Gyepes, Gyepes-völgy, Keserűi-völgy, Keserű-orom, Keserű-tető - a Keserű-oromtól délre eső hegy, Kis-barlang-bérc, Kisbarlang-völgy, Kis-Poporó, Macska-lyuk, Nagy-barlang-völgy, Nagy-Poporó, Nyír-völgy, Pataj-fő, Remete-bérc, Szedres-ág-bérc, Zsá-völgy; Borsodnádasd: Karácsonylova, Szőlő-bérctető (SJ), Ulnai-Bikkfő (BÁ); Domaháza: Holló-fészek, Körte-tető, Máté-Bükk, Nyárjasság, Sípós-árnyék (SJ); Hangony: Biriny-völgy (BÁ), Petyke-bérc (SJ); Istenmezeje: Békák-bérc, Hagymás-gödör, Hagymás-völgy (BÁ), Tamás telke-fö, Víz-lápa-fő, Völgy-árnyék-bérc; Kissikátor: Csurgó, Keselyűs-Bikk-árnyék, Két-ág-lápa, Köleses-bérc, Telekes-patak-völgye, Tiszta-tető; Ózd: Körtvészer-tető (SJ), Nagy-oldal, Tótok-erdeje, Zsófi János; Pétervására: Garics; Sajópüspöki: Hosszú-tető (BÁ), Kanizsa-tető; Szentdomonkos: Borz-fő, Hosszúvölgy-dűlő (SJ); Tarnalelesz: Pataj-völgy (BÁ); Váraszó: Csókás-hegy (SJ), Demjén-fő (BÁ), Farkas-lyuk-padja, Fenekes, Fenekes-völgy (SJ), Forró-kút-fö (BÁ), Gemeruta-bérc, Hosszúágy, Kenyér-domb, Kerek-dél, Kis-dél (SJ), Kis-Ves-völgy, Málnás-bérc, Nagy-Herceg (BÁ), Nagy-Ves-völgy, Nyárjas-völgy (SJ), Tódor-láb-hegyese, Tölgyes-tető (BÁ); Pm: Hevesaranyos: Barci-far, Ecser-patak völgye, Kis-Ecser; Szentdomonkos: Akol-mellett; Tarnalelesz: Csigdászó; Uh: Arló: Asszony-berki, Izra-völgy, Kovács-tető - az Asszony-berkitől északra eső 308 m-es hegy, Lőrinc-árnyéka, Macó-bérc (SI); Borsodnádasd: Balatoni Cseres-bérc, Budaberke, Budaberki-völgy, Csiterkötő, Dér-tető, Mesgye-hegy, Vásáros-úti-völgy (BÁ); Csernely: Pete-fia, Varnyas-orom (SJ); Csokvaomány: Nyékes-tető, Szőlő-völgy, Szőlő-völgyfő (BÁ); Járdánháza: Szalinca (SJ), Tó-pad (BÁ). CEU: [7786.4], [7787.1], [7787.2], [7787.3], [7788.1], [7788.3], [7788.4], [7886.1], [7886.2], [7886.3], [7886.4], [7887.1], [7887.2], [7887.3], [7887.4], [7888.1], [7888.2], [7888.3], [7986.1], [7986.2], [7986.4], [7987.1], [7987.2], [7987.3], [8087.1].

2681. Listera ovata (L.) R. Br. - A dombvidéken igen ritka fajnak eddig három előfordulása volt ismert (SULYOK \& SCHMOTZER 1999), mindenhol csak egy-két egyeddel. Bh: Bekölce: Róna-bérc - gyertyános-tölgyes szálkaperjés szegélyében egy virágzó egyed; Tv: Járdánháza: Cselény-völgy - üde rezgőnyaras erdőszegélyben egyetlen tő (SJ). CEU: [7887.3], [7987.2].

2686. Platanthera bifolia (L.) Rchb. - Mészkerülő erdőkben, erdőszegélyekben, útrézsűkben, ritkábban mészkerülő gyepekben. Uhg: Bánhorváti: Bárci-oldal; Dédestapolcsány: Köszörűs és varjas; Sajómercse: Ágazat-völgy; Tv: Arló: Elő-Poporó, Kis-barlang-bérc, Kisbarlang-völgy, Nádú-árnyék, Remete-völgy; Borsodszentgyörgy: Közép-orom, Vadberke (SJ); Domaháza: Aszaló-Bikk, Asztag-völgy-bérc, Asztag-völgy-hegy (BÁ), Hajagos (SJ), Kerek-Bükk; Hangony: Magas-hegy; Istenmezeje: Hagymás-eleje, Szép-orom (BÁ); Járdánháza: Cselény-völgy; Kissikátor: Tiszta-tető; Váraszó: Csókás-völgy, Demeterek; Pm: Tarnalelesz: Fingászó-hegy-orma; Uh: Arló: Bagó-lápa, Macó-bérc (SJ); Borsodnádasd: Budaberkivölgy (BÁ); Csernely: Eperjes, Úszó-fő; Sajómercse: Adár-bérc (SJ). CEU: [7787.3], [7788.3], [7788.4], [7886.1], [7886.2], [7886.4], [7887.1], [7887.2], [7887.3], [7887.4], [7888.2], [7986.1], [7987.3]. 
2686,1. Platanthera × hybrida Brügger - Előfordulásának jelentőségét az adja, hogy az egyik szülő faja a $P$. chlorantha is igen ritka a dombvidéken. A hibrid előfordulása előre vetíti, hogy a közelben valahol még előkerül a $P$. chlorantha. A legközelebbi ismert előfordulása a Gömör-Tornai-karsztról származik Bódvaszilas mellől (VIRóK et al. 2010). Új az Upponyi-hegyhátra. Uh: Csernely: Borsostartó-tető - szálkaperjés melegkedvelő tölgyesben egy virágzó egyed (SJ). CEU: [7887.4].

2687. Platanthera chlorantha (Custer) Rchb. - A rendkívül ritka fajnak eddig csak egyetlen adata volt ismert a Tarnavidékről a tarnaleleszi Remete-völgyből (BENEDEK \& ZAY 1987). Tv: Hangony: Disznóverem - egyetlen példánya tölgyes szélén, az országhatáron futó turistaút mentén (BÁ). CEU: [7786.4].

2688. Gymnadenia conopsea (L.) R. Br. - Üdébb szálkaperjés gyepekben, erdőszegélyekben ritka. Az Upponyi-hegység északi részéből lett eddig publikálva (SulYoK 2011). Bh: Egerbocs: Fedémesi-völgy - mezofil erdőszegélyben 20 egyed; Hevesaranyos: Vár-hegy - vágásterületen, szálkaperjés gyepfoltban idős bükk hagyásfák mellett egy egyed; Uhg: Sáta: Tőkés-völgy - lápréten egy virágzó tő; Uppony: Upponyi-szoros - nyúlfarkfüves sziklagyepben egy virágzó növény; Uh: Sajómercse: Kerek-rét - szálkaperjés réten 6 tő, Körtvélyes egy virágzó növény erdőszegélyben lévő szálkaperjés gyepben (SJ). CEU: [7788.3], [7788.4], [7888.1], [7987.3].

2693. Dactylorhiza incarnata (L.) Soó - Magassásréteken, lápréteken. A Tarnavidéken nem ritka. Tv: Arló: Gyepes-völgy, Keresztenyik-völgy (SJ), Zár-fő, Zár-rét (BÁ); Borsodnádasd: Hasznos, Kört-völgy, Róna-Bükk-völgy (SJ); Borsodszentgyörgy: Kalitka-völgy, Kántor-lápa, Teresznek-völgy, Zár-rét; Domaháza: Asztag-völgy (BÁ), Felső-völgy, Hintós-völgy (SJ), Keselyűs-Bikk-völgy, Kis-kút és Utas-völgy (BÁ), Magas-verő (SJ), Örvényes-völgy (BÁ), Répás-völgy (SJ), Son-torok, Sózó-völgy (BÁ), Zálogos (SJ); Hangony: Kortvány-völgy (BÁ); Járdánháza: Cselény-völgy, Köves-hegy (SJ); Kissikátor: Hangony-völgy; Zabar: Szekeresbükk-völgy (BÁ); Óm: Járdánháza: Hódos-patak-völgye (SJ); Ózd: Hangony-patak (BÁ); Uh: Arló: Arlói-tó, Bagó-lápa, Csahó-völgy; Borsodnádasd: Mocsolyás-völgy; Járdánháza: Mocsolyás-völgy; Sajómercse: Mercse-patak-völgye, Szörnyű-völgy (SJ). CEU: [7786.4], [7787.3], [7788.3], [7886.1], [7886.2], [7886.3], [7887.1], [7887.2], [7887.3], [7887.4].

2693,3. Dactylorhiza incarnata (L.) Soó subsp. serotina (Hausskn.) D.M. Moore et Soó Lápréteken ritka. Tv: Borsodszentgyörgy: Kántor-lápa; Domaháza: Miklós-fája; Óm: Ózd: Bak-völgy (BÁ). CEU: [7787.4], [7886.2], [7887.1].

2693,5. Dactylorhiza incarnata (L.) Soó var. ochrantha Landwehr - Uh: Arló: Vár-hegy gyapjúsásos lápréten egy töve (SJ). CEU: [7887.2].

2694. Dactylorhiza majalis (Rchb.) P.F. Hunt et Summerh. - Gyapjúsásos láprétek ritka növénye. Tv: Borsodszentgyörgy: Kántor-lápa (BÁ); Domaháza: Felső-völgy (SJ), Son-torok (BÁ); Járdánháza: Cselény-völgy; Uh: Arló: Arlói-tó (SJ), Csahó-völgy, Vár-hegy (BÁ). CEU: [7886.2], [7887.1], [7887.2], [7887.3].

2694,1. Dactylorhiza × aschersoniana (Hausskn.) Borsos et Soó - Gyapjúsásos lápréteken a szülőfajok közt ritka. Tv: Borsodszentgyörgy: Kántor-lápa; Domaháza: Son-torok (BÁ); Járdánháza: Cselény-völgy (SJ). CEU: [7886.2], [7887.1], [7887.3].

2700. Orchis morio L. - Mészkerülő félszáraz gyepekben, legelőkön nem ritka. Bh: Bátor: Szónya; Bükkmogyorósd: Alsó-sűrű-bérc, Alsó-sűrű-lápa, Csurgó, Sűrű-lápa; Sirok: Temetőfelett; Uhg: Borsodbóta: Epres-mál, Vatos, Veres-domb, Veres-tető; Sáta: Szőlő-gyakra (SJ); Tv: Domaháza: Csurgó-bérc, Kerek-Bükk, Kis-kút és Utas-völgy, Mihály-tető, Nehák, Telekfelé, Utas-fő; Erdőkövesd: Igaz-völgy; Hangony: Meggyes-tető (BÁ), Mihászó-orom (SJ); Istenmezeje: Hagymás-eleje; Zabar: Kő-verő-hegy; Pm: Bükkszenterzsébet: Szőlő-megi-hegy; Erdőkövesd: Fehér-agyag-dűlő, Tiszán (BÁ); Fedémes: Árpaszó-hegy, Meggyes-oldal; Tarnalelesz: Fingászó-hegy-orma, Gásztászó, Kastály-legelő, Meszes, Nagy-hegyesse; Uh: Csernely: Ali-út-tető, Ecetes-Tök, Eperjes, Kerek-völgy-tető, Nyékes-tető; Csokvaomány: Pap- 
hegyese (SJ), Vén-szőlő (BÁ). CEU: [7786.4], [7787.3], [7788.3], [7886.1], [7886.2], [7887.2], [7887.4], [7888.1], [7888.3], [7985.2], [7986.1], [7986.2], [7986.4], [7987.3], [8087.2], [8087.3].

2702. Orchis tridentata Scop. - Szálkaperjés gyepekben nem ritka. Bh: Bátor: Boza; Borsodnádasd: Láz; Bükkmogyorósd: Nagy-bérc; Uhg: Bánhorváti: Máli-oldal; Borsodbóta: Sáros-út, Tó-padja, Veres-tető (SJ); Dédestapolcsány: Hosszú-berek-tető (BÁ), Nagy-hegy, Nagy-hegyi-szőlő, Nagy-hegy-orom; Sáta: Hosszak és Kéri-tó, Kotyindó-tető, Pipis-hegy (SJ); Uppony: Mogyorós-gödre, Róka-mál (BÁ); Tv: Borsodnádasd: Karácsonylova, Kerekberek-fö, Lapuhas, Lapuhas-völgy, Róna-Bükk (SJ); Ózd: Aklos, Szenna-fő; Tarnalelesz: Henc-ortvány; Zabar: Kő-verő-hegy - itt enyhén mészkerülő gyepben (BÁ); Óm: Borsodnádasd: Szalinca; Pm: Tarnalelesz: Nagy-hegyesse; Uh: Borsodbóta: Kerek-rét (SJ); Borsodnádasd: Balatoni Cseres-bérc, Balatoni-tető, Budaberke, Mesgye-hegy (BÁ); Csernely: Aliút-tető, Borjúmáj (SJ), Csiga-hajas-oldal, Ecetes-Tök (BÁ), Gárdony-tető, Mák-völgy, Nemecke, Papharaszt, Pete-fia (SJ); Csokvaomány: Andornak (BÁ), Babos (SJ), Farkas-tető (BÁ), Liba-tető, Nyékes-tető, Palánt-tető, Pap-hegyese (SJ), Szilfás, Vén-szőlő; Járdánháza: Tó-pad (BÁ); Sajómercse: Adár-bérc, Kerek-rét, Kisbikk, Mercse-patak-völgye, Nagy-hegy, Nyúzó-völgy, Őr-tető, Tarkai-parlag (SJ). CEU: [7787.4], [7788.3], [7788.4], [7886.1], [7887.2], [7887.3], [7887.4], [7888.1], [7888.2], [7888.3], [7987.1], [7987.2], [7987.3], [7987.4].

2704. Orchis purpurea Huds. - Félszáraz gyepekben, felhagyott szőlőkben és gyümölcsösökben, cserjésekben, parlagokon, melegkedvelő és cseres-tölgyesekben, gyertyánostölgyesekben, bükkösökben, erdőszegélyekben. Bh: Bátor: Boza, Megyaszó-fő, Pusok-tető, Szónya; Bükkmogyorósd: Alsó-sűrű-lápa, Csepegő-bérc, Csiga-völgy, Csurgó, Eresztvénybérc, Nagy-bérc, Salamon-vár, Salamon-vár-alja; Egerbocs: Fedémesi-völgy; Hevesaranyos: Dakó-hegye, Dancs, Dóna-útja-bérc, Ecser-bükk - SULYok \& SCHMOTZER (1999) ecser-tetői adata ide vonatkozik, Ecser-hegy, Gyilkos-tető, Kis-bügör, Kopasz-orom, Körtélyes, Nagybügör, Nagy-lápa, Őr-hegy-laposa, Pusok-tető, Ürge-hegy, Veres-hegy; Uhg: Bánhorváti: Máli-oldal; Borsodbóta: Gyűre, Hosszak, Tó-padja, Vatos, Veres-domb, Veres-tető (SJ); Dédestapolcsány: Balta-tető (BÁ), Halabuka-tető, Hosszú-berek-tető, Kerek-domb, Köszörűs és varjas, Kukorica-föld, Nagy-hegy-alja (SJ), Nagy-hegyi-szőlő, Nagy-hegy-orom, Rigó-tető, Sordé-tető (BÁ), Varjas-szőlő (SJ); Nekézseny: Avas-bérc (BÁ), Szőlő-mál-tető; Sajómercse: Mercse-ágazat; Sáta: Hosszak és Kéri-tó, Kotyindó-tető, Pipis-hegy (SJ); Uppony: Csipelesdomb, Dedevár, Upponyi-szoros, Vízköz; Tv: Borsodnádasd: Kerek-berek-fő (SJ); Bükkszenterzsébet: Dobogó-bérc; Hangony: Egres-oldal, Felső-kő-völgye; Istenmezeje: Hagymás-eleje; Ózd: Bika-pad, Cseres-tető, Csonkás, Harmaci-völgy-fő, Nagy-oldal (BÁ), Pásztorkert-fő (SJ), Sóskút-tető, Szenna-tető, Szőr-lápa, Vár-völgy, Zsófi János (BÁ), Óm: Ózd: Akasztó-domb (SJ), Borbás-hegy (BÁ); Pm: Bükkszék: Pina-hegyes (SJ); Erdőkövesd: Újhegy (BÁ); Fedémes: Kútos-tető; Hevesaranyos: Barci-far, Dobogó-tető, Sirokaszó-fő (SJ); Szentdomonkos: Pap-hegy; Váraszó: Ó-hegy, Vagdaszó-bérc (BÁ); Uh: Arló: Ladány-tető, Lőrinc-árnyéka, Macó-bérc, Szohony (SJ), Tó-pad; Borsodnádasd: Balatoni-tető, Csiterkötő, Mesgye-hegy, Mocsolyás-tető, Vásáros-úti-völgy (BÁ); Csernely: Borsostartó-tető (SI), Csiga-hajas-oldal (BÁ), Eperjes, Kerek-völgy-tető, Nemecke, Pete-fia, Varnyas-orom (SJ); Csokvaomány: Andornak (BÁ), Babos (SJ), Határ-bérc (BÁ), Liba-tető (SJ), Szilfás, Szőlő-völgy, Vén-szőlő; Járdánháza: Mocsolyás-völgy-fő - a Mocsolyás-völgy keleti végében lévő hegy (BÁ); Királd: Őr-tető; Sajómercse: Adár-bérc, Gógány, Kerek-rét, Nagy-hegy, Nyúzó-völgy, Ốr-hegy, Szarvaskút, Szörnyü-völgy, Tarkai-parlag (SJ). CEU: [7786.4], [7787.1], [7787.2], [7787.3], [7787.4], [7788.3], [7788.4], [7887.2], [7887.3], [7887.4], [7888.1], [7888.2], [7888.3], [7986.1], [7986.2], [7986.4], [7987.1], [7987.3], [7987.4], [8086.2], [8087.1], [8087.2]. 
2705. Orchis militaris L. - Szálkaperjés gyepekben. Bh: Bátor: Boza; Bükkmogyorósd: Alsósűrü-bérc, Alsó-sűrű-lápa, Csepegő-bérc, Csiga-völgy, Csurgó, Nagy-bérc, Salamon-vár, Teresztyén; Hevesaranyos: Kis-bügör, Körtélyes, Köszörűs; Uhg: Borsodbóta: Tó-padja, Vatos; Dédestapolcsány: Nagy-hegy-orom; Sáta: Kotyindó-tető (SJ); Uppony: Cibróka, Róka-mál (BÁ); Tv: Borsodnádasd: Karácsonylova, Kerek-berek-fő, Lapuhas, Lapuhas-völgy (SJ); Bükkszenterzsébet: Dobogó-bérc; Tarnalelesz: Henc-ortvány (BÁ); Pm: Fedémes: Meggyeslápa; Hevesaranyos: Bodony-árnyék, Kaptás, Sirokaszó; Tarnalelesz: Dancsok (SJ); Váraszó: Ó-hegy (BÁ); Uh: Arló: Bagó-lápa, Lőrinc-árnyéka (SJ); Borsodnádasd: Balatoni Cseres-bérc, Balatoni-tető, Budaberke (BÁ); Csernely: Ali-út-tető, Ali-völgy (SJ), Csiga-hajas-oldal (BÁ), Eperjes, Nemecke, Pete-fia (SJ); Csokvaomány: Vén-szőlő; Járdánháza: Tó-pad (BÁ); Sajómercse: Adár-bérc, Gógány, Körtvélyes, Mercse-patak-völgye, Nyúzó-völgy, Szörnyü-völgy (SJ). CEU: [7788.3], [7788.4], [7887.2], [7887.3], [7887.4], [7888.1], [7888.2], [7888.3], [7986.2], [7986.4], [7987.1], [7987.2], [7987.3], [7987.4], [8087.1], [8087.2].

2705,1. Orchis $\times$ hybrida Boenn. ex Rchb. - Szálkaperjés gyepekben a szülőfajokkal együtt. Bh: Hevesaranyos: Köszörűs; Uhg: Sáta: Kotyindó-tető (SJ); Pm: Szentdomonkos: Paphegy; Uh: Borsodnádasd: Balatoni Cseres-bérc (BÁ); Csernely: Kerek-völgy-tető (SJ). CEU: [7887.4], [7888.1], [7987.1], [8087.2].

\section{Köszönetnyilvánítás}

Köszönetünket szeretnénk kifejezni Kalapos Tibornak a Ferula telepítéssel kapcsolatos információk megosztásáért, Takács Bélának a Cypripedium calceolus megtalálásához, Molnár V. Attilának, Pifkó Dánielnek, Sulyok Máténak a terepi munkában, Somlyay Lajosnak a terepmunkában és a herbárium megtekintésében, Barina Zoltánnak a herbárium megtekintésében, Schmotzer Andrásnak az adatai átadásáért, Farkas Sándornak és Vojtkó Andrásnak a begyűjtött növények határozásában nyújtott segítségéért.

\section{Irodalom}

BAKALÁR S-né, ORBÁN S., Pócs T., SubA J. \& VAjDA L. (1975): Adatok a Tarnavidék mohaflórájához. - Studia Botanica Hungarica 10: 111-114.

BAKAlÁR S-né, ORBÁn S., SuBA J. \& TAKÁcs B. (1982-83): A Cypripedium calceolus L. feltárt termőhelyei a Bükk-hegységben és környékén. - Folia Historico Naturalia Musei Matraensis 8: 77-84.

BARÁz Cs. (2014): Alacsony középhegységek a Bükk ÉNY-i előterében (Vajdavár-hegység, Upponyihegység). - In: Diczházi I. \& Schmotzer A. (szerk.), Apoka. A Heves-Borsodi-dombság és az Upponyihegység élővilága. Bükki Nemzeti Park Igazgatóság, Eger, pp. 7-16.

BARTHA D., BöLÖNI J. \& KIRÁlY G. (1999): Magyarország ritka fa- és cserjefajai. - Tilia 7: 1-286.

Bartha D., Király G., Schmidt D., TiborcZ V., Barina Z., CSiky J., JAKAB G., LeSKu B., SChmotZer A., VidéKi R., Vojtкó A. \& ZólYomi Sz. (szerk.) (2015): Magyarország edényes növényfajainak elterjedési atlasza. Nyugat-magyarországi Egyetem Kiadó, Sopron, 329 pp.

Bauer N., Mészáros A. \& Galambos I. (2002): A Gagea bohemica (Zauschn.) Schult. et Schult. élőhelyválasztásának vizsgálata. - Kitaibelia 7(2): 215-223.

Beneder O. \& Zay A. (1987): Adatok a Heves-megyei Észak-Tarnavidék flórájához. - Folia Historico Naturalia Musei Matraensis 12: 19-20.

BERÁNEK Á. (2007): Adatok a Heves-Borsodi-dombság és az Upponyi-hegyhát flórájához I. - Kitaibelia 12(1): 66-72.

BERÁNEK Á. (2008): Adatok a Heves-Borsodi-dombság és az Upponyi-hegyhát flórájához II. - Kitaibelia 13(1): 34-45.

BERÁNEK Á. (2009): Rövid közlemények - Az Orobanche flava Mart. ex F.W. Schultz. új előfordulása Észak-Magyarországon. - Flora Pannonica 7: 80.

Boros Á. (1922): Florisztikai jegyzetek 8, 17, 20, 27, 45, 46. - Kézirat, 187, 123, 190, 218, 116, 166 pp. 
Boros Á. (1938): Florisztikai közlemények II. - Botanikai Közlemények 35(5-6): 310-320.

BUDAI J. (1912): A bélapátfalvi Bélkőhegy flórája. - Magyar Botanikai Lapok 11(1-4): 68-71.

BUDAI J. (1913): Újabb adatok a Bükk hegység és dombvidéke flórájához. - Magyar Botanikai Lapok 12: 315-327.

BudAI J. (1914): Adatok Borsodmegye flórájához. - Magyar Botanikai Lapok 13: 312-326.

Buschmann F. (2013): A jászberényi Jász Múzeum növénygyűjteménye (Herbarium-collection in Musei Jazigiae Jászberényiensis). - Tisicum 22: 259-291.

CzÁfLIK P. (1989): Észak-Tarna vidék kétéltű- és hüllőfaunájának alapvetése. - Folia Historico Naturalia Musei Matraensis 14: 135-137.

Czimber Gy., Horváth K., Radics L. \& Szabó L. Gy. (1990): Vorkommen und wirtschaftliche Bedeutung von zwei neuen mediterranen Arten [Diplotaxis erucoides (Torner) D.C. und Ammi majus L.] in Ungarn. Acta Ovariensis 32(1): 5-11.

CsiKY J. \& Judik B. (1998): Az Orchis simia Lam. előfordulása az Északi-középhegységben. - Kitaibelia 3(1): 129-130.

CSIKY J. \& KóвOR I. (2001): Újabb adatok a Nógrád-Gömöri bazaltvidék (Karancs, Medves, Cerová Vrchovina) flórájához. - Kitaibelia 6(2): 281-289.

CSIKY J. (2004): A Karancs, a Medves-vidék és a Cerová vrchovina (Nógrád-Gömöri bazaltvidék) flóra és vegetációtérképezése, Pécs, 451 pp.

CSIKY J., SulYok J. \& Schmotzer A. (1999): Adatok a Salgótarján körüli oligocén kori homokkő flórájához. - Kitaibelia 4(1): 55-63.

Csorba P. (szerk.) (2018): Tájak. - In: Kocsis K. (főszerk.): Magyarország Nemzeti Atlasza: természeti környezet. Magyar Tudományos Akadémia, Csillagászati és Földtudományi Kutatóközpont, Földrajztudományi Intézet. Budapest, pp. 112-129.

DövÉNYI Z. (szerk.) (2010): Magyarország Kistájainak Katasztere. MTA Földrajztudományi Kutatóintézet, Budapest, $876 \mathrm{pp}$.

GulYás G. \& VIRóK V. (2000): Apró közlemények - 9. Blysmus compressus (L.) Panzer és Epipactis palustris (L.) Cr. a Bükkben. - Kitaibelia 5(1): 228.

Gulyás S. \& CZimber Gy. (1990): Apicultural importance of Diplotaxis erucoides (Torner) D.C. - Acta Ovariensis 32(1): 12-17.

Harmos K. \& Sramkó G. (2000): Adatok a Mátra edényes flórájához I. - Kitaibelia 5(1): 63-78.

HEVESI A. (1978): A Bükk szerkezet- és felszínfejlődésének vázlata. - Földrajzi Értesítő 27(2): 169-203.

HuLjÁK J. (1933): A Micromeria rupestris Wulf. a Bélkőn és néhány érdekesebb adat a Magyar Középhegység flórájából. - Magyar Botanikai Lapok 32: 77-83.

KÁRÁsz I. (1991): A verpeléti Várhegy flórája és természetvédelmi értékelése. - Acta Academiae Paedagogicae Agriensis 20: 117-131.

KÁRPÁTI Z. (1960): Die Sorbus-Arten Ungarns und der angrenzenden Gebiete. - Feddes Repertorium 62: 71-334.

KATONA Cs. (2006): Vajdavár-homokkővidék. - Kornétás Kiadó, Budapest, 136 pp.

KERÉNYI-NAGY V. (2010): Ritka rózsafajok és hibridek (Rosa spp.) - Tilia 15: 191-270.

KIRÁLY G. \& HoRVÁtH F. (2000): Magyarország flórájának térképezése: lehetőségek a térképezés hálórendszerének megválasztására. - Kitaibelia 5(2): 357-368.

KIRÁLY G. \& KIRÁLY A. (2018): Adatok és kiegészítések a magyar flóra ismeretéhez III. - Botanikai Közlemények 105(1): 27-96.

KIRÁLY G. (szerk.) (2009): Új magyar füvészkönyv. Magyarország hajtásos növényei. Határozókulcsok. Aggteleki Nemzeti Park Igazgatóság, Jósvafo, 616 pp.

KovÁCs M. \& MátHÉ I. (1964): A mátrai flórajárás (Agriense) sziklavegetációja. - Botanikai Közlemények 51: 2-18.

KovÁcs M. (1962): Übersicht der Bachröhrichte (Glycerio-Sparganion) Ungarns. - Acta Botanica Academiae Scientiarum Hungaricae 8: 109-143.

LENGYEL G. (1906): Florisztikai adatok Heves-vármegye északi részéből. - Növénytani Közlemények 5(1): 9-20., 51-56.

LőKös L. (szerk.) (2001): Diaria itinerum Pauli Kitaibelii III. - Magyar Természettudományi Múzeum, Budapest, $462 \mathrm{pp}$.

MALATinSZKY Á. (2007): A Putnoki-dombság florisztikai kutatásának újabb eredményei. - Kitaibelia 12(1): 124-132. 
Marosi S. \& Somogyi S. (szerk.) (1990): Magyarország Kistájainak Katasztere I-II. MTA Földrajztudományi Kutatóintézet, Budapest, 1026 pp.

MolnÁr Cs. \& CZúcZ B. (2009): A virágos kőris (Fraxinus ornus L.) terjedése és mai termőhelyei az Északi-középhegységben. - Botanikai Közlemények 96(1-2): 71-81.

MolnÁR Cs. (2001): Új adatok a Mátra déli és keleti részének növényvilágából I. - Kitaibelia 6(2): 347361.

MoLNÁR Cs. (2002): Új adatok a Mátra déli és keleti részének növényvilágából II. - Kitaibelia 7(2): 169182.

MolnÁr Cs., Beránek Á., Haszonits Gy., Pintér B., Korda M., Peregrym M., NótÁri K., Malatinszky Á. \& Toldi M. (2019): Pótlások Magyország edényes növényfajainak elterjedési atlaszához IX. - Kitaibelia 24(2): 253-256.

Molnár Cs., Haszonits Gy., Malatinszky Á., Kovács G. K., Kovács G., NaGy T., MolnáR V. A. \& TakÁcs A. (2017): Pótlások Magyország edényes növényfajainak elterjedési atlaszához III. - Kitaibelia 22(1): 122-146.

Molnár V. A. (szerk.) (2011): Magyarország orchideáinak atlasza. - Kossuth Könyvkiadó, Budapest, 504 pp.

NaGY T., NótÁRi K., TAKÁcs A., Malkócs T., TöKöLYi J. \& Molnár V. A. (2018): Precipitation and timing of flowering in Ghost orchids (Epipogium aphyllum Sw.). - Acta Botanica Hungarica 60(1-2): 223-230.

Pelles G. (1999): Gyepes nefelejcs. - In: FARKAS S. (szerk.), Magyarország védett növényei. Mezőgazda Kiadó, Budapest. p. 195.

PenKSZA K. \& MALATINSZKY Á. (2001): Adatok a Putnoki-dombság edényes flórájához. - Kitaibelia 6(1): $149-155$.

PIFKó D. (2004): Adatok a hazai Chamaecytisus fajok ismeretéhez I. - Flora Pannonica 2(2): 25-36.

PifKó D., SoMLYAY L. \& LőKös L. (2003): Apró közlemények - 2. Adatok a Zempléni-hegység flórájához. Kitaibelia 8(1): 187.

ProdÁn Gy. (1909): Adatok a Bükk- és előhegyeinek flórájához. - Botanikai Közlemények 8(3): 103-117.

Schmotzer A. (2004): A szilvásváradi Aszaló növényzete. - Acta Academiae Paedogicae Agriensis, Sectio Biologiae 25: 59-72.

Schmotzer A. (2015): Ceratocephala testiculata (Crantz) Roth és további adatok a Bükkalja flórájához. Kitaibelia 20(1): 81-142.

SEREGÉLYES T. (1999): Fekete fodorka. - In: FARKAS S. (szerk.), Magyarország védett növényei. Mezőgazda Kiadó, Budapest. p. 91.

Somlyay L. \& SENNikov A. N. (2016): Atlas Florae Europaeae notes 25. Taxonomic circumscription and nomenclature of Sorbus danubialis (Rosaceae). - Nordic Journal of Botany 34: 75-86.

Soó R. (1937): A Mátrahegység és környékének flórája. Magyar Flóraművek I. Editio Instituti Botanici Universitatis Debreceniensis, Debrecen, 89 pp.

Soó R. (1943): Előmunkálatok a Bükkhegység és környéke flórájához. - Botanikai Közlemények 40: 169-221.

SRAmkó G., Magos G., MolnáR Cs. \& URBÁN L. (2008): Adatok a Mátra és környéke edényes flórájának ismeretéhez. - Kitaibelia 13(1): 74-93.

Sramkó G., VojtKó A., HARmos K. \& MAgos G. (2003): Adatok a Mátra és környéke edényes flórájának ismeretéhez. - Kitaibelia 8(1): 139-160.

SuBA J. (1963): Adatok a Tarna-vidék flórájához. - Acta Academiae Paedogicae Agriensis 9: 253-261.

SUBA J. (1969): A Tarna-vidék flórájának kritikai elemzése. - Acta Academiae Paedogicae Agriensis Nova Series 7: 379-413.

SUlYOK J. \& SCHMOTZER A. (1999): Adatok a Tarna-vidék és a Bükk északi előterének flórájához I. Kitaibelia 4(2): 367-380.

SULYOK J. (2011): Adatok az Upponyi-hegyhát északi részének flórájához. - Kitaibelia 15(1-2): 133-144.

SULYOK M. \& SUlYOK J. (2011): Az Epipogum aphyllum (F. W. Schmidt) Sw. előfordulása a Bükk hegységben. - Kitaibelia 16(1-2): 97-98.

SzMoRAD F. (1999): Adatok az Aggteleki-karszt és a Galyaság flórájához I. - Kitaibelia 4(1): 77-82.

TAKÁCS G. (1999): Apró közlemények - 4. Cephalanthera × Schulzei Cam. \& Ber. a Bükk-fennsíkon. Kitaibelia 4(1): 203.

ViróK V., FARKAS R., GulYÁs G. \& SRAMKó G. (2010): Florisztikai adatok Borsod-Abaúj-Zemplén megye északi részéről III. - Kitaibelia 15(1-2): 73-82. 
VIRÓK V., FARKAS R., SZMORAD F. \& BOLDOGHNÉ SZƯTS F. (2004): Florisztikai adatok Borsod-Abaúj-Zemplénmegye északi részéről. - Kitaibelia 9(1): 143-150.

VojTKó A. \& MARSCHALL Z. (1991): Védett növények állományfelmérésének eredményei a Bükk hegységben. - Acta Academiae Paedagogicae Agriensis 20: 161-166.

Vojtкó A. \& SulYoк J. (2014): A Tarnavidéki Tájvédelmi Körzet növényvilága. - In: DiczhÁZI I. \& Schmotzer A. (szerk.), Apoka. A Heves-Borsodi-dombság és az Upponyi-hegység élóvilága. Bükki Nemzeti Park Igazgatóság, Eger, pp. 17-34.

VojTKó A. (1994): Adatok a Bükk hegység flórájához. - Botanikai Közlemények 81(2): 165-175.

Vojтќ́ A. (1995): Az Upponyi szoros vegetációtérképe. - Acta Academiae Agriensis Nova Series 21 Supplement 1: 363-370.

VojtKó A. (1999): A Valeriana simplicifolia (Reichenb.) Kabath hazánkban és újabb adatok a Bükk hegység flórájához. - Kitaibelia 4(1): 25-35.

VojTKó A. (2001): A Bükk hegység flórája. - Sorbus 2001 Kiadó, Eger, 340 pp.

VojTKó A. (2008): Florisztikai adatok Észak-Magyarországról. - Kitaibelia 13(1): 55-61.

VRABÉLYI M. (1868): Adatok Hevesmegye virányisméjéhez. Heves és Külső-Szolnok vármegyék leírása. Eger, pp. 142-164.

ZóLYOMI B. (1928): Adatok a Bükk-hegység és környéke flórájához. - Magyar Botanikai Lapok 26: 63-64.

ZólYomi B. (1934): Dracocephalum austriacum L. a Bélkőn (Adatok az Ôsmátra flórájához). - Botanikai Közlemények 31(1-2): 35-37.

\section{Hivatkozott világháló oldalak}

[1] OBM - Hungarian Flora Atlas - floraatlasz.uni-sopron.hu/index.php?map (Hozzáférés: 2019.07.26.) Beérkezett / received: 2019. 05. 09. • Elfogadva / accepted: 2019. 09. 05. 